
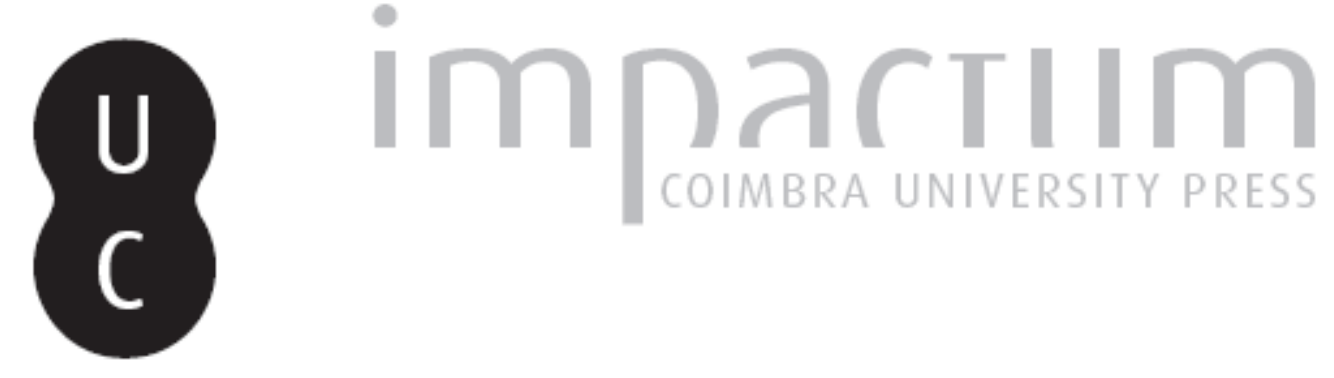

\title{
À porta duma quinta do Alto Império: resultados preliminares do estudo intra-sítio do assentamento romano de "Terlamonte I" (Teixoso, Covilhã)
}

Autor(es): $\quad$ Silva, António J. M.; Carvalho, Pedro C.

Publicado por: Faculdade de Letras da Universidade de Coimbra

URL persistente:

URI:http://hdl.handle.net/10316.2/37703

DOI:

DOI:http://dx.doi.org/10.14195/1647-8657_43_5

Accessed : $\quad$ 26-Apr-2023 14:41:01

A navegação consulta e descarregamento dos títulos inseridos nas Bibliotecas Digitais UC Digitalis, UC Pombalina e UC Impactum, pressupõem a aceitação plena e sem reservas dos Termos e Condições de Uso destas Bibliotecas Digitais, disponíveis em https://digitalis.uc.pt/pt-pt/termos.

Conforme exposto nos referidos Termos e Condições de Uso, o descarregamento de títulos de acesso restrito requer uma licença válida de autorização devendo o utilizador aceder ao(s) documento(s) a partir de um endereço de IP da instituição detentora da supramencionada licença.

Ao utilizador é apenas permitido o descarregamento para uso pessoal, pelo que o emprego do(s) título(s) descarregado(s) para outro fim, designadamente comercial, carece de autorização do respetivo autor ou editor da obra.

Na medida em que todas as obras da UC Digitalis se encontram protegidas pelo Código do Direito de Autor e Direitos Conexos e demais legislação aplicável, toda a cópia, parcial ou total, deste documento, nos casos em que é legalmente admitida, deverá conter ou fazer-se acompanhar por este aviso.

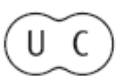


CONIMBRIGA

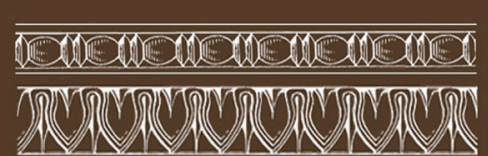

INSTITUTO DE ARQUEOLOGIA

VOLUME XLIII - 2004

FACULDADE DE LETRA

UNIVERSIDADE DE COIMBRA 
António J. M. Silva

AMS - Análise e Consultadoria Arqueológica Ld. ${ }^{a}$

Pedro C. Carvalho

Instituto de Arqueologia. Faculdade de Letras da Universidade de Coimbra

À PORTA DUMA QUINTA DO ALTO IMPÉRIO. RESULTADOS PRELIMINARES DO ESTUDO INTRA-SÍTIO DO ASSENTAMENTO ROMANO DE “TERLAMONTE I” (TEIXOSO, COVILHÃ) "Conimbriga" XLIII (2004) p. 99-147

RESUMO: Este texto apresenta os resultados preliminares de uma investigação que pretende reconstruir a envolvência imediata de um estabelecimento rural da região da Cova da Beira (Portugal), no Alto Império. Pretende-se assim alargar o conhecimento do quotidiano dos seus habitantes para além das portas do edifício que os albergou. Para esse efeito, escolheu-se como objecto de estudo o sítio de Terlamonte I (Teixoso, Covilhã), cuja área edificada foi anteriormente alvo de várias campanhas de escavação arqueológica, no quadro do projecto de investigação "O povoamento rural romano da Cova da Beira".

A particularidade desta nova análise reside no facto de se centrar na área envolvente deste sítio, num total de 2,5 hectares, e de recorrer a uma estratégia multidisciplinar, tendo por objectivo o reconhecimento e a compreensão da antropização de todo este espaço. Instrumentos de pesquisa, como a prospecção de superfície em quadrícula e a prospecção geomagnética, foram complementados por uma campanha de sondagens arqueológicas, que proporcionaram a recolha de amostras posteriormente sujeitas a análises radiocarbónicas e geoarqueológicas. Um sistema de informação geográfica intra-sítio congregou os contributos destes diferentes métodos. A apresentação dos primeiros resultados deste estudo, ainda em curso, serve de pano de fundo a uma discussão sobre o contributo, as perspectivas e os limites destes diferentes métodos no quadro do conhecimento do povoamento rural romano. 
RÉSUMÉ: Ce texte présente les résultats préliminaires d'un project de recherche qui prétend reconstruir l'enquadrement immédiat d'un établissement rural de la région de la Cova da Beira (Portugal), durant le Haut Empire. On prétend ainsi étendre la connaissance du quotidien de ses habitants au delà des portes de l'édifice qui les a hébergés. L'objet d'étude est le site de Terlamonte I (Teixoso, Covilhã), dont l'espace habitationnel a été précédemment fouillé au long de plusieurs campagnes archéologiques, dans le quadre du projet "Le peuplement rural romain de la Cova da Beira".

Cette nouvelle analyse du site a comme particularité le fait de s'intéresser au voisinage imédiat du site, avec une aire d'étude de 2,5 hectares et de recourir a une estratégie multidisciplinaire, ayant pour objectif l'identification et la compréhension de l'anthropisation de tout cet espace. Des instruments de recherche, comme la prospection de surface en carreaux et la prospection géomagnétique, ont été complétés par une campagne de sondages archéologiques, qui ont permis le prélèvement d'échantillons ultérieurement soumis à des analyses radiométriques et géoarchéologiques. Un système d'information géographique intra-site a faculté l'analyse intégrée des résultats de ces différentes approches. La présentation des premiers résultats de cette recherche, encore en cours, sert de prétexte à une discussion du contribut, des perspectives et des limites de ces différentes méthodes dans le quadre de la connaissance du peuplement rural romain. 


\section{À PORTA DUMA QUINTA DO ALTO IMPÉRIO RESULTADOS PRELIMINARES DO ESTUDO INTRA-SÍTIO DO ASSENTAMENTO ROMANO DE “TERLAMONTE I" (TEIXOSO, COVILHÃ)}

\section{Introdução}

\section{1. Âmbito e objectivos}

A imagem que habitualmente um arqueólogo constrói mentalmente quando visualiza o sítio que intervenciona é a de um edifício ou conjunto de edifícios inscritos numa tela branca. Por vezes, a tela branca é substituída por uma paisagem estereotipada que o arqueólogo associa - por analogia com outras paragens melhor conhecidas - ao contexto cronológico da estação estudada. Esta percepção resulta em grande parte do facto da concepção que se advoga para "sítio arqueológico" englobar apenas a área intra-muros, não abarcando as estruturas e espaços exteriores relacionados com a actividade desenvolvida pelos seus habitantes. A nossa perspectiva, porém, procura não confinar um sítio arqueológico às paredes que o delimitam, abrangendo também outras áreas contíguas - inclusivamente não cobertas - onde actividades de vária índole - algumas relacionadas com as próprias práticas diárias de subsistência e outras com uma frequência mais limitada ou mesmo sazonal - tinham lugar (BINTLIFF, 2000).

O alargamento do conhecimento de um sítio para fora da sua porta de entrada obriga o arqueólogo a alargar significativamente o âmbito da estratégia de intervenção, assim como o leque de métodos e técnicas usadas. A escavação passa a ser apenas uma ferramenta entre muitas outras. Este tipo de abordagem - e na qual se moveu a investigação que dá corpo a este texto - é geralmente designada como análise espacial intrasítio (intra-site spatial analysis) ou de escala micro-espacial, uma vez 
que se pretende determinar as relações espaciais existentes entre as estruturas e os materiais, de modo a definir o uso diferenciado do espaço dentro de um mesmo sítio (EsPiago e BAENA, 1997: 43).

Convirá também referir, antes de mais, que este estudo - cujos resultados preliminares agora se divulgam - é o fruto de um encontro entre, por um lado, um projecto de investigação que tem como objecto genérico de análise o povoamento romano da região que hoje é conhecida pelo nome da Cova da Beira, e, por outro lado, um outro projecto que visa encontrar e testar ferramentas que permitam reconstruir a envolvência imediata de um sítio arqueológico ${ }^{1}$.

O assentamento romano de "Terlamonte I" tornou-se a partir de 2001 o ponto de convergência destes dois projectos. Ao primeiro projecto, interessava alargar o conhecimento de um sítio, onde já se tinha investido desde do ano anterior uma parte significativa dos recursos disponíveis para a sua realização, articulando essa intervenção com outras escalas de análise espacial de âmbito regional. Ao segundo projecto, interessava beneficiar de um manancial significativo de informação previamente recolhida, relevante para a compreensão da estratégia de ocupação do espaço e de exploração dos recursos por parte dos habitantes do sítio analisado. A firme intenção de continuar a investigação do sítio para além deste estudo perspectivava também descobertas posteriores que possibilitariam a validação dos seus resultados.

Findo três anos desde o início desta colaboração, chegou a altura de divulgar os seus primeiros resultados. Estes deverão necessariamente ser entendidos como provisórios, quer porque as descobertas resultantes do estudo inicial suscitaram a aplicação - ainda em curso - de novos métodos, quer porque a intervenção arqueológica da área edificada deste assentamento - igualmente em curso - proporciona todos os anos novos dados relevantes no quadro desta problemática.

$1 \mathrm{O}$ primeiro inscreve-se no Projecto de Investigação $O$ povoamento romano na região da Cova da Beira (IPA-PNTA: 2000-2003), que serve de base à dissertação de doutoramento que PCC tem em preparação, enquanto que o segundo projecto foi objecto de uma dissertação de mestrado em Arqueologia, apresentada por AJMS - em Novembro de 2002 - na Faculdade de Letras de Coimbra e intitulada $O$ assentamento romano de Terlamonte I: prospecção de superfície, prospecção geofísica, SIG e estudos intra-sítio, tendo como co-orientador Fernando de Almeida (Dep. Geociências da Univ. Aveiro). Ambos os processos de investigação contaram com a orientação continuada e o incentivo inestimável do Doutor Jorge de Alarcão, a quem desejamos expressar a nossa mais elevada estima e gratidão. 


\subsection{Quadro geográfico e arqueológico}

Inscrevendo-se na região natural da Cova da Beira, depressão aplanada - por vezes quebrada por elevações abruptas e isoladas - delimitada pelas serras da Estrela e da Gardunha a poente, pelos planaltos da Meseta Ibérica a norte, pela Serra da Malcata a nascente e pela Superfície de Castelo Branco a sul e cortada pelo rio Zêzere (RIBEIRO, 1949), o sítio de "Terlamonte I" situa-se concretamente na encosta sudeste do outeiro de Pinheiros Lusos (Teixoso, Covilhã) - um dos relevos residuais que marcam o interior da Cova da Beira - e a cerca de 500 $\mathrm{m}$ do curso pouco sinuoso do Zêzere, num terreno a espaços arborizado com carvalhos e pinheiros e onde habitualmente é cultivado cereal de sequeiro (Fig. 1 e Foto 1$)^{2}$.

Geologicamente está situado numa área de granito calco-alcalino, biotítico e porfiróide de grão grosseiro, pela qual se estendem vários filões de quartzo, e nas proximidades da larga superfície aluvial actual que bordeja o rio e de algumas pequenas explorações mineiras abandonadas de estanho e volfrâmio (TEIXEIRA et alii, 1974). Os solos, não muito espessos e evoluídos, com uma baixa acidez e alcalinidade inscrita numa classe de $\mathrm{pH}$ (em água) superior ou igual a 4.5 e facilmente afectados pelos processos erosivos - dada a sua permeabilidade reduzida e face ao predomínio dos granitos facilmente desagregáveis quando afloram à superfície -, apresentam uma capacidade de uso agrícola moderada, sendo actualmente classificáveis nas classes D e E.

Em termos arqueológicos, o sítio romano de "Terlamonte I" insere-se numa zona marcada aparentemente por uma vincada ruralidade, resultante, em grande parte, da ausência de uma verdadeira urbs - como centro estruturador do território e palco privilegiado de expressão e difusão da nova ordem - e do facto das villae - se entendidas como sedes de grandes unidades de exploração agro-pecuária pertencentes a indivíduos cuja riqueza e integração nos valores da cultura clássica se manifestava, nomeadamente, na presença dos urbana ornamenta nas suas residências de campo - constituirem um elemento claramente raro na paisagem (CARvalho, 2003). Com efeito, a natureza dos vestígios de superfície identificados nesta região parecem sugerir que o povoamento rural

2 As suas coordenadas geográficas (Meridiano de Greenwich, Datum Europeu 1950, Elipsóide Internacional) são as seguintes: Lat. 40. '17'32 ', Long. 7. 25'29', , Alt. 460 m (CMP. 1/25.000-n. $\left.{ }^{\circ} 235\right)$. 
romano na Cova da Beira se encontra estruturado com base essencialmente numa rede de núcleos que poderemos interpretar como quintas e casais. Estas sedes de explorações de carácter familiar, pelo menos em certas áreas, surgem com uma densidade considerável, quer organizadas em redor ou em função de um aglomerado populacional de maior envergadura, quer posicionadas em zonas que possibilitavam a exploração de uma ampla gama de recursos, não só de natureza agrícola e silvopastoril, como também mineira, uma vez que é conhecida a riqueza desta região em estanho e ouro (CARVALHO et alii, 2002).

\section{3. "Terlamonte I": a área edificada}

Ainda que o objectivo deste texto, como já deixámos subentendido, não seja a apresentação do sítio romano de Terlamonte I na sua componente edificada propriamente dita - análise essa que reservamos para outra oportunidade -, será conveniente, todavia, para uma melhor contextualização dos elementos que obtivemos na sua envolvente, adiantar desde já alguns dos principais traços que o caracterizam³.

Assim, em função dos trabalhos de escavação que decorreram entre 2000 e 2003, parece desde já possível interpretar este sítio como uma quinta ou granja - cuja ocupação poderá ser fixada provisoriamente entre os meados do séc. I e os finais do séc. II d. C. - que constituiria a sede duma média unidade de exploração agro-pecuária dotada de uma relativa autonomia ou auto-suficiência, se atendermos ao conjunto de materiais e equipamentos já identificados. Em termos gerais, este núcleo rural apresenta um plano construtivo unitário, concebido, aparentemente, em função da necessidade de articular racionalmente diferentes espaços funcionais - dotando-os da necessária habitabilidade e adequando-os às actividades que se desenrolariam quer no seu interior, quer no exterior mais imediato ou noutros pontos mais afastados da sua propriedade - e de se adaptar às características topográficas específicas da vertente em que se implantou, uma vez que se desenvolve em duas áreas ou corpos espacialmente distintos - e com níveis de circulação

3 Este sítio - ou a área onde este e outros sítios nas suas imediações se encontram - foi pela primeira vez referenciado por Helena Frade (1996: 887), tendo a partir daí sido avançada para ele(s) uma classificação que não se coaduna com os resultados dos trabalhos feitos posteriormente na área (CARVALHO, 2003: 169).

Conimbriga, 43 (2004) 99-147 
que correm a cotas desiguais. Estes dois corpos, se atendermos configuração e à articulação dos compartimentos que os integram e se considerarmos a distribuição micro-espacial das estruturas e dos artefactos identificados no seu interior, parecem ser funcionalmente dissemelhantes. Um desses corpos edificados - ligeiramente sobrelevado - albergaria a parte propriamente residencial da quinta, enquanto que o outro - aberto aparentemente para um terreiro interior não telhado - seria talvez um espaço preferencialmente vocacionado para os processos de trabalhos relacionados com as actividades desenvolvidas na área envolvente, como parece testemunhar a recolha de um conjunto de pesos de tear ou os vestígios de uma pequena forja e de uma possível area de um lagar rudimentar.

A boa exposição solar que decorre do facto de se posicionar numa encosta virada para SE, a protecção natural aos ventos do norte proporcionada pelos fortes declives - criados por um talude - que ladeiam o edifício nessa direcção -, a boa drenagem dos terrenos envolventes, a ampla visibilidade de que goza o sítio sobre o vale do Zêzere e o amplo espectro de recursos naturais potencialmente exploráveis, terão sido certamente razões que não terão sido alheias à escolha do local para edificar este estabelecimento.

Refira-se ainda que as prospecções já realizadas na zona envolvente desta estação permitiram identificar, essencialmente, uma série de pequenos sítios - revelados por reduzidas concentrações de materiais romanos à superfície - que poderão ter mantido, pelo menos alguns deles, um vínculo directo com "Terlamonte I", como será talvez o caso de um local, junto à larga superfície de aluvião que bordeja o Zêzere, onde se podem sobretudo observar grandes blocos de escória e que poderá ter correspondido a uma outra área de fundição (Fig. 1).

\section{Estratégia e metodologia}

Alargar o conceito de sítio para além dos espaços construídos implica trabalhar com áreas de intervenção bem superiores àquelas geralmente definidas na investigação de sítios rurais romanos. Neste caso concreto, esta área foi fixada arbitrariamente em 2,5 ha. Pretendia-se encontrar neste espaço evidências (arqueofactos e ecofactos), que permitissem compreender a forma como os habitantes da quinta ocuparam e exploraram o espaço imediatamente envolvente ao sítio. 
A fase inicial deste estudo consistiu assim no rastreio e na localização de elementos passíveis de interpretação. Assumiu-se como princípio, desde logo, que a recolha destes dados dever-se-ia processar duma forma sistemática, rápida e pouco onerosa. Por este motivo, decidiu-se recorrer a duas técnicas exploratórias com provas dadas desde longa data: a prospecção de superfície em quadrícula ${ }^{4}$ e a prospecção geomagnética. A primeira, porque permitiria delimitar áreas construídas e áreas onde se desenvolveram actividades que podiam não se associar a qualquer tipo de estrutura arqueológica (GERRARD, 1995: 141). A segunda, porque permitiria detectar estruturas arqueológicas muito subtis, que poderiam mesmo passar desapercebidas numa escavação menos atenta, como sejam buracos de poste, valas, estruturas de combustão não estruturadas, etc. (CLARK, 2000: 65-66).

A abundância e o carácter espacial da informação recolhida nesta fase conduziu à elaboração de um Sistema de Informação Geográfica (SIG) onde esta foi tratada e analisada em conjunto com a informação micro-topográfica referente à área de estudo, de maneira a formular um primeiro modelo de ocupação do espaço com base nas possíveis evidências de antropização detectadas pelas prospecções. A interpretação proposta para as estruturas através da prospecção geofísica foi de seguida testada através de um programa de sondagens arqueológicas que incidiram sobre aquelas que pareciam ser mais relevantes para a compreensão do conjunto. Os resultados da intervenção destas sondagens levantaram por sua vez novos problemas e novas dúvidas, tornando-se necessário resolvê-las através de análises geoarqueológicas (ainda em curso).

\subsection{Trabalhos preliminares}

A malha quadriculada usada neste estudo - ocupando uma área total de 2,5 ha - foi orientada em função das escavações que já tinham sido efectuadas no local, de forma a facilitar a análise comparativa dos resultados de ambos os trabalhos 5 . A piquetagem do terreno da nova malha foi efectuada com o recurso a uma estação total.

4 AJMS apresentou recentemente uma pequena síntese sobre os fundamentos teóricos deste método, no quadro da publicação dos resultados de outra intervenção (Silva e Silva, no prelo).

5 A malha anterior, orientada pelo norte magnético, era constituída por quadrados de $4 \mathrm{~m}$ de lado. 
Dois sistemas de referenciação local foram usados ao longo dos trabalhos que se seguiram (Fig. 2):

O primeiro, designado por "srA", foi concebido de modo a facilitar a realização da prospecção intensiva. A malha é assim constituída pelos sectores A, B, C, D, E, F, G, H, I, J, K e L. Cada sector é constituído por quadrados de $5 \times 5 \mathrm{~m}$, organizados em filas paralelas ao eixo $\mathrm{S} / \mathrm{N}$. A referenciação local nesta malha recorre ao tri-nome: sector (A-L), n. ${ }^{\circ}$ de fila (de 1 a 10 , que cresce de $\mathrm{O}$ para E), n. ${ }^{\circ}$ de quadrado (de 1 a 10, em crescendo de $\mathrm{S}$ para $\mathrm{N}$ ). No decurso dos trabalhos, optouse por materializar no terreno apenas as filas 7, 8, 9 e 10 dos sectores $\mathrm{C}$ e F e K, bem como as filas 3, 4, 5, 6, 7, 8, 9 e 10 do sector I. Exceptuando-se estes sectores, todos os restantes foram completamente materializados, totalizando cada um 10 filas de 10 quadrados.

Paralelamente a este primeiro sistema de referenciação, estruturado por sector / fiada / quadrado, definiu-se um segundo ( $\mathrm{srB}$ ) onde um ponto de qualquer sector é localizado através de um único sistema cartesiano de coordenadas X e Y. Atribuiu-se arbitrariamente a coordenada $(\mathrm{X}=50, \mathrm{Y}=0)$ ao canto $\mathrm{SO}$ do sector $\mathrm{L}$, de modo a que as coordenadas de todos os pontos da área de estudo sejam sempre positivas. Este sistema foi usado na prospecção geomagnética, bem como na integração dos dados no Sistema de Informação Geográfica.

Como forma de possibilitar os trabalhos de prospecção geomagnética e de prospecção de superfície em quadrícula, procedeu-se também à desmatação - durante sete dias - de toda a área em análise com recurso a meios mecânicos e manuais.

De forma a garantir a localização precisa da zona de estudo para futuros trabalhos, efectuou-se - recorrendo-se a uma estação total - à geo-referenciação dos pontos notáveis da malha (a localização das estacas no quadro da malha, bem como as suas respectivas coordenadas, também podem ser consultadadas na Fig. 2). Seguiu-se um levantamento topográfico de pormenor da área de estudo e da envolvente imediata - num total de 36.266 pontos. A georeferenciação dos pontos efectuou-se no sistema de coordenadas HG73, ou seja Haydford Gauss Datum 73 (MATOS, 2001: 26). O " $z$ " das coordenadas assim definidas corresponde à distância vertical de cada ponto em relação ao nível do mar (datum vertical: Marégrafo de Cascais). Este levantamento incluiu ainda a localização das sondagens arqueológicas efectuadas até então, dos montes de terra provenientes da escavação, dos afloramentos, dos bosques e das árvores isoladas, bem como das áreas de giestal queima- 
das recentemente. Procedeu-se ainda ao levantamento de um muro identificado durante os trabalhos de desmatação no sector D.

\subsection{Sistema de Informação Geográfica}

Usou-se o programa Arcview Gis v. 3.2a da Esri Inc. na elaboração do SIG. Trata-se de um programa vocacionado para a análise de informação espacial de tipo vectorial, embora permita a integração de camadas de informação de tipo raster. De modo a preencher esta lacuna, a análise da informação raster foi processada através de um programa vocacionado para este tipo de dados, o MS Works 2.6 Gold Edition da Thinkspace Inc., importando-se posteriormente a informação para o Arcview.

A área espacial tratada neste SIG corresponde à área de estudo. Todas as camadas de informação são constituídas por dados de diferentes tipos recolhidos especificamente para este fim, não se recorrendo a qualquer tipo de informação externa. A informação representada neste SIG tem como origem o levantamento topográfico de pormenor acima referido, os resultados da prospecção intensiva em quadrícula e os resultados da prospecção geomagnética. A informação proveniente do levantamento topográfico foi tratada no programa MS WORKS, de modo a produzir a partir dela um mapa de declives, um mapa de orientação de vertentes e um mapa de drenagem do terreno.

\subsection{Prospecção de superfície em quadrícula}

A prospecção de superfície em quadrícula - que decorreu em Abril de 2001 ao longo de três dias úteis - incidiu sobre os 2,5 ha que totalizam a área de estudo. As condições climatéricas mantiveram-se constantes durante toda a duração do trabalho de campo, traduzindo-se por um período de sol, com algumas nuvens e temperaturas amenas.

Os trabalhos contaram com a participação de 5 prospectores, com um bom nível de conhecimento de materiais arqueológicos - a mesma equipa que efectuou a desmatação - e de um director de prospecção (PCC) - com a necessária experiência na classificação de materiais romanos - que procedeu ao registo dos dados. 
A cada prospector foram atribuídas duas filas por sector, adoptando-se os quadrados de 5 x 5m anteriormente definidos como unidade de prospecção (Fot. 2). Foram assim prospectados 970 dos 1.000 quadrados de $5 \times 5 \mathrm{~m}$ que constituem a área de estudo. Foi impossível prospectar os 30 restantes quadrados (que representam apenas 3\% do total), pelo facto destes coincidirem em parte ou na totalidade com as sondagens efectuadas anteriormente (17 quadrados), com a presença de montes de terra provenientes dessas intervenções (11 quadrados) ou com a presença de grandes afloramentos (2 quadrados). De uma forma geral, este factor apenas limitou seriamente os resultados deste estudo nas envolvências das duas sondagens (Sond. 3 e 6) intervencionadas anteriormente.

Em cada quadrado, os prospectores reuniram a totalidade do material antrópico que foi possível recolher do solo sem recorrer a nenhum instrumento. Para cada quadrado, o director de prospecção procedeu à sua identificação / classificação e à sua quantificação, segundo as taxas referidas mais à frente (Foto 3 ).

Todo o material cerâmico foi ainda objecto de pesagem, com recurso a uma balança analógica de cozinha, com precisão de $10 \mathrm{~g}$. Os valores lidos na balança foram sempre arredondados para múltiplos de $25 \mathrm{~g}$ a partir de $50 \mathrm{~g}$, peso mínimo que foi atribuído aos conjuntos de massa inferior ou igual a esse valor e superiores a $0 \mathrm{~g}$. As contagens discriminaram a cerâmica de construção romana (maioritariamente constituída por tegula, later, imbrex), a cerâmica comum de mesa ou de ir ao lume (potes, panelas, tijelas, jarros ...), a cerâmica comum de armazenamento (dolia), a terra sigillata, os pesos de tear, as escórias, os minérios e os seixos de granito rolados. Os dados foram compilados numa ficha elaborada especificamente para este efeito. Para além da referência por cada quadrado prospectado, aos resultados da contagem da totalidade do material e à pesagem do material cerâmico, o director registou igualmente o nome do prospector e as condições de visibilidade do terreno, tomando ainda nota da hora de início e de fim dos trabalhos em cada sector.

O grau de visibilidade - boa, má ou nula - foi avaliado pelos próprios prospectores, verificando-se que, para além dos 30 quadrados não prospectados, 6,6\% dos quadrados apresentavam uma visibilidade nula e 7,6\% apresentavam uma má visibilidade. Os quadrados que correspondem a uma visibilidade nula ou limitada enquadram-se geralmente em zonas de bosque, exceptuando-se a faixa de quadrados que corta a 
meio o sector L, onde a má visibilidade se devia à elevada densidade do estrato herbáceo. Seja como for, de uma forma geral, não se pode considerar este factor como um constrangimento sério ao aproveitamento dos resultados deste estudo, uma vez que os prospectores avaliaram como sendo boa a visibilidade em $82,8 \%$ dos casos.

Uma vez classificado e contabilizado, o material foi de seguida espalhado pelo quadrado onde foi identificado, à excepção daquele que pudesse posteriormente permitir aprofundar o conhecimento da cultura material e da dimensão cronológica do sítio. Os materiais que se enquadram nesta última categoria foram recolhidos, identificando-se o seu local de achado no sistema de referenciação local. Foram igualmente recolhidas algumas amostras de escória e de minério para serem analisadas no quadro de análises posteriores.

Posteriormente, a informação constante nas fichas de campo foi introduzida numa base de dados com recurso ao software FileMaker Pro 5 da CLARIS, de forma a possibilitar a sua análise quantitativa bem como a sua posterior integração no quadro do Sistema de Informação Geográfica, referido anteriormente.

\subsection{Prospecção geomagnética}

A prospecção geomagnética decorreu entre os dias 26 e 28 de Maio de 2001 e envolveu três pessoas. A aquisição dos dados geofísicos seguiu um processo muito próximo daquele usado na prospecção intensiva, uma vez que os dados foram recolhidos por fiadas dentro de cada sector. A recolha de medições processou-se por sector, cada um deles sendo inteiramente prospectado por um único prospector, de modo a isolar a possível influência do operador na perturbação das medições.

A prospecção efectuou-se assim em toda a área de estudo, totalizando 182.661 medições, obtidas com recurso a um magnetómetro a vapor de césio modelo G-858 da Geometrics, equipado com um sistema de aquisição automática de medições (Foto 4). Optou-se pelo esquema de prospecção de tipo zig zag (DAVID, 1995: 18), recolhendo leituras com uma resolução de $0,03 \mathrm{nT} / \mathrm{m}$, um intervalo de tempo entre cada medição de 0,2 segundos, um afastamento entre fiadas de $0,5 \mathrm{~m}$, bem como uma distância entre pontos de controle de $10 \mathrm{~m}$. Os dois sensores do magnetómetro foram montados num mesmo eixo vertical e separados 
um do outro por $0,8 \mathrm{~m}$ de forma a obter medições em gradiente vertical. Durante a prospecção tentou-se manter sempre o sensor inferior a $0,2 \mathrm{~m}$ da superfície do solo.

Ao fim de cada dia de trabalho de campo, os dados memorizados pelo magnetómetro foram descarregados para um computador portátil, com recurso ao software MagMap 2000 da Geometrics, correspondendo cada ficheiro (em formato BIN) a um sector. Um erro fatal na transferência dos dados originou a perda definitiva do ficheiro relativo ao sector I. O tempo estipulado e os recursos financeiros disponíveis para este tipo de intervenção não permitiram a repetição da prospecção neste quadrado.

De todas as alternativas de mapeamento possíveis, optou-se pela apresentação do mapa geomagnético em formato raster. Preferiu-se esta forma uma vez que a representação através de isolinhas de valores mais divulgada entre nós - apresenta o inconveniente de se adaptar mal a dados que evoluem rapidamente e que são espacialmente pouco coerentes, para além da leitura do "relevo" gerado pelas isolinhas não ser óbvia por parte de um leigo (DABAS, 1998: 176). Por sua vez, a apresentação do mapa em formato raster tem também como vantagem um processamento mais adequado da configuração geométrica das anomalias, na condição - como é o caso - de se trabalhar com elevadas densidades de medições. Neste formato, cada medição corresponde a um pixel cuja posição na imagem corresponde à sua posição na malha de estudo. A cor ou a tonalidade de cinzento que é atribuído ao ponto corresponde à amplitude magnética da medição em nT. Essa tonalidade é seleccionada automaticamente pelo computador numa escala de cores, havendo uma relação directa entre a posição da cor na paleta e a posição do valor da medição no conjunto ordenado das medições efectuadas. Renunciou-se ao uso de cores no mapeamento dos dados, preferindo-se o recurso a uma escala de cinzentos, devido ao facto de o olho humano conseguir discriminar uma maior gama de variações nesses tons (Idem: ibidem). Assim, como a legis arts desta disciplina o exige, os tons mais claros ficaram associados a elevados valores de amplitude do campo magnético enquanto que os tons mais escuros correspondem a valores de menor amplitude. 


\subsection{Sondagens de controle}

Com base nos resultados proporcionados pelos trabalhos de prospecção de superfície em quadrícula e de prospecção geomagnética, foi levada a cabo em Setembro de 2001 - ao longo de 12 dias - uma campanha de escavações arqueológicas que tinha como objectivo genérico avaliar ou determinar as causas que motivavam as anomalias geomagnéticas registadas - como veremos - no exterior da suposta área edificada ou telhada de "Terlamonte I".

Para o efeito, foi delineada uma estratégia de intervenção que consistiu na marcação e abertura de cinco sondagens (Sond. 1, 2, 4, 5 e 7) especificamente localizadas em função da análise dos mapeamentos proporcionados pelos trabalhos prévios de prospecção (Fig. 3).

Durante a escavação, optou-se sempre pelo processo estratigráfico, procurando-se escavar os depósitos respeitando as suas próprias formas e contornos naturais, sendo estes numerados e descritos como entidades individuais e retirados pela sequência inversa àquela em que foram depositados, de forma a possibilitar a compreensão e a reconstituição da ordem sequencial de deposição das diversas unidades estratigráficas (HARRIS, 1989). Cada unidade estratigráfica (UE) foi registada fundamentalmente em termos da sua composição física (cor, compacticidade, textura e tipo de inclusões), da sua localização espacial, das suas relações estratigráficas e dos eventuais materiais arqueológicos que continha, sendo ainda integrada numa dada categoria interpretativa básica (RoskAMs, 2001). Ainda que o processo adoptado privilegiasse à partida a observação e o registo em planta de cada uma das unidades ou de um conjunto de unidades contemporâneas nos diversos planos que se sucediam, no final da escavação de cada sondagem desenharam-se sempre as sequências estratigráficas visíveis nos cortes.

\subsection{Geoarqueologia}

Ainda que tenhamos conseguido reunir algumas condições que proporcionaram, como vimos, a articulação concertada de diferentes tipos de abordagem em "Terlamonte I", o nível de resolução colocado na análise intra-espacial de um sítio exigiria que essa transversalidade de perspectivas - particularmente activas desde a fase de planificação dos trabalhos, passando pelo processo de recolha e interpretação dos 
dados e culminando na sua explicação contextual - fosse estendida e englobasse as disciplinas do âmbito alargado da Geoarqueologia. Com efeito, a natureza das informações que resultam do tipo de dados que estas analisam pode propiciar uma compreensão mais fundamentada sobre a repartição diferenciada das actividades e dos usos do solo em toda a área - interna e externa aos espaços edificados - onde o sítio arqueológico se desenvolve, ao identificar a composição orgânica e mineral dos solos e sedimentos estratificados, assim como os agentes ou processos responsáveis pela sua formação ou deposição (BUTZER, 1989). Nesta fase de investigação, porém, alguns destes procedimentos foram inviabilizados face às limitações da plataforma de meios e recursos que a suportaram.

Alguns trabalhos, todavia, foram levados a cabo nesta área. Desde logo, como resultado da colaboração facultada por Fernando de Almeida (Dep. Geociências da Univ. Aveiro), Lídia Catarino e Fernando Pedro Figueiredo (Dep. Ciências da Terra da Univ. Coimbra), foi possível proceder à identificação de alguns materiais rochosos recolhidos em prospecção e escavação. Outros procedimentos encontram-se ainda em curso sob a responsabilidade de Paulo Morgado (Dep. Geociências da Univ. Aveiro). Estes incidem sobre uma série de amostras de sedimento e rocha recolhidas nas estruturas em negativo identificadas inicialmente pela prospecção geomagnética e posteriormente confirmadas pela escavação. Por enquanto, encontram-se processados os resultados da análise química por "Inductively Coupled Plasma - Atomic Emission Spectromery" (ICP-AES), efectuada no laboratório "ACME Analytical Laboratories" (Vancouver, Canadá) ${ }^{6}$. Os dados até agora obtidos, como veremos, ainda não são conclusivos e carecem de ser cotejados com elementos resultantes de outros tipos de análise que se encontram programadas - análises granulométricas e micromorfológicas de sedimentos e, eventualmente, análises térmico-diferenciais e dilatometria - e que poderão revelar-se fundamentais para determinar a funcionalidade de algumas estruturas identificadas.

Por sua vez, ao nível da arqueobotânica também foram desenvolvidas algumas acções, fruto de um protocolo de colaboração estabelecido com o Centro de Investigação em Paleocologia Humana e Arqueociências. Neste quadro, foi realizado, sob a direcção de Paula Queiroz,

6 O estudo já efectuado incidiu sobre 9 amostras de solo/sedimento, rocha/minério e escória com vista a identificar o teor de 30 elementos químicos previamente definidos. 
Win Van Leeuwaarden e José Eduardo Mateus, um ensaio de análise polínica de sedimentos silto-arenosos que constituíam o enchimento da vala identificada na sondagem 7 e procedeu-se também à identificação de um conjunto de material lenhoso carbonizado recolhido na fossa identificada na sondagem 2 (QuEIROz et alii, 2003).

Por último, na tentativa de obter elementos cronológicos para o conjunto de estruturas em negativo identificadas nas sondagens de controle - uma vez que, como veremos, não foi possível identificar aí durante a escavação qualquer material arqueológico associado passível de datação absoluta - foram recolhidos alguns carvões nas sondagens 1, 2 e 7 e enviados para o Centrum voor Isotopen Onderzoek (Groningen) como forma de serem objecto de datação radiocarbónica.

\section{Resultados}

\subsection{Prospecção de superfície em quadrícula}

A representatividade da amostra analisada é garantida pelo elevado número de materiais identificados durante a prospecção intensiva (7807 materiais). Neste lote existe uma sobre-representação da cerâmica (7666 unidades / 653,360 kg) em relação aos outros tipos de espólio, uma vez que esta representa cerca de $98 \%$ do conjunto, sendo por este motivo o tipo de espólio que merecerá maior atenção no quadro deste estudo.

Por outro lado, na área em análise, apenas se verificou a presença de materiais com cronologia romana, de modo que parece seguro à partida o estabelecimento de uma relação directa entre a amostra estudada e a ocupação romana do sítio, definida desde o início como objecto de estudo.

As densidades de cerâmica serão aqui analisadas através do índice Cer calculado segundo a seguinte fórmula:

$$
\operatorname{Cer}_{i}=\frac{p_{i} \times q_{i}}{100}
$$

$p_{i}$ - peso total de cerâmica observada no quadrado $i$

$q_{i}$ - quantidade total de cerâmica observada no quadrado $i$ 
Quando se medem pequenas densidades de materiais, o índice é pouco influenciado pelo peso e aproxima-se fortemente do número de fragmentos observados. Em importantes densidades de materiais, o índice tende a aproximar-se do peso em detrimento da contagem. A aplicação deste índice permite assim atenuar as distorções de ambos os indicadores, quando eles adoptam valores mais críticos (Gráfico 1 e SiLVA, 2002: 43).

Uma rápida leitura de um histograma das densidades de cerâmica revela um comportamento da amostra que foge ao padrão Gaussiano com elevadas frequências nas primeiras classes e uma cauda pesada que se estende até aos 11280.

De modo a objectivar a constituição de classes de densidades de cerâmica, recorreu-se ao utilitário de classificação automática do Arcview. Optou-se por definir 10 intervalos de valores pelo método de quebras naturais (natural breaks ou Jenk's optimization), que minimiza a variação dentro de cada classe, posicionando os limites entre cada intervalo de valores onde se verificam os maiores aumentos de frequência. Este método de classificação tem a vantagem de evidenciar os valores extremos (ESRI, 1996: 104).

A primeira classe de valores $(0-56 \mathrm{Cer})$ foi posteriormente fraccionada em três classes, como forma de isolar os quadrados onde não se recolheram materiais, daqueles onde o material recolhido era residual ou pouco significativo. Escolheu-se a mediana da distribuição do índice Cer de todos os quadrados prospectados como limite superior desta classe de valor, ou seja 0,5Cer. A escolha da mediana em detrimento da média fundamenta-se no facto deste indicador de localização ser menos dependente do comportamento dos extremos em populações com distribuições com caudas pesadas fugindo ao padrão Gaussiano (MURTEIRA, 1993:71).

As restantes classes de valores foram finalmente agrupadas em três grandes classes genéricas correspondentes a densidades pouco significativas, densidades medianas e fortes densidades de materiais cerâmicos. Este agrupamento foi efectuado por aproximações, de forma a que estas novas classes tivessem a maior coerência espacial possível, para facilitar a interpretação da organização espacial do sítio. Recorreu-se para este efeito ao programa Ms Works, de modo a visualizar o mapeamento dos valores de concentração em função dos agrupamentos efectuados.

De todo este processo, resulta a seguinte classificação:

- 0 Cer - material cerâmico ausente 
- 0 à 0,5 Cer - densidade de cerâmica residual

- 0,5 à $56 \mathrm{Cer}$ - densidade de cerâmica pouco significativa

- 56 à 643,5 Cer - densidade de cerâmica mediana

- 643,5 à 11.280 Cer - densidade de cerâmica elevada

Como era de esperar (Gráfico 2), a cerâmica de construção constitui a esmagadora maioria do material identificado, representando mais de $88,88 \%$ do conjunto. Segue-se, mas com uma representatividade muito menor, a cerâmica comum de mesa $(4,59 \%)$ e de armazenamento $(4,56 \%)$ - exclusivamente feita ao torno - com proporções muito próximas entre si. Os valores percentuais atingidos pela sigillata, pesos de tear, escórias e seixos rolados são apenas residuais. Estes seixos pareciam ter como origem directa o leito do Zêzere, que corre a algumas centenas de metros para sul da encosta onde se situa a área de estudo. Todavia, a sua presença neste local parece ficar a dever-se - como escavações posteriores parecem sugerir - à presença adentro da área edificada de, pelo menos, um pavimento constituído por este material, encontrando-se parcialmente destruído pelas lavras.

Em todo o conjunto de material identificado registou-se a ausência de fragmentos de ânforas, cerâmica de paredes finas, lucernas, metais, vidros ou de quaisquer indícios que revelassem a existência de $u r$ bana ornamenta no local, como sejam as tesselae, estuques (pintados) ou elementos arquitectónicos e escultóricos. Em escavação, todavia, foram recolhidos - para além de escassos fragmentos de cerâmica de paredes finas e de lucernas - alguns fragmentos de vidro e inúmeros fragmentos de metal (ferro e bronze). Assim sendo, quando se estabelece um paralelo entre material enterrado e material de superfície, será necessário ter em consideração a sub-representação de materiais muito sensíveis à oxidação, como é o caso do vidro e do ferro. A degradação de cerâmicas mais friáveis em contacto com a atmosfera foi igualmente verificada por Gerrard (1995: 140), com base num programa de microsondagens de controle que permitiu estabelecer a relação entre material à superfície e material soterrado até $0,25 \mathrm{~m}$ de profundidade. Este factor terá, no entanto, pouco significado quando se trata de materiais mais duradouros ou resistentes como o mármore de revestimento ou mesmo a terra sigillata.

Nos 1.000 quadrados prospectados, observaram-se materiais em 608 quadrados $\left(15.200 \mathrm{~m}^{2}\right)$. O mapeamento dos resultados da prospecção intensiva em harmonia com a classificação acima referida (Fig. 4) revela que existe uma acentuada assimetria entre a densidade de cerâ- 
mica observada nas duas metades da área de estudo, separadas por um eixo que a atravessa sensivelmente a meio, com orientação SE/NO. É notório que grande parte do material registado durante a prospecção se encontra para SO desta linha. Ao mesmo tempo, verificou-se que a mancha de dispersão em análise se confinava aos limites escolhidos inicialmente - de forma empírica - para a área de estudo, com excepção apenas das zonas para poente e para sul do sector I. Este facto deve ser tomado em consideração quando se tenta determinar a área ocupada pela mancha de dispersão, sem no entanto o querer sobrevalorizar. De facto, a mancha apresenta já densidades pouco significativas nestas áreas, rodeadas algumas dezenas de metros mais à frente - para noroeste - por relevos que constituíram certamente um limite natural da ocupação do sítio.

Uma análise mais fina da mancha de dispersão de materiais permite verificar que esta não é uniforme, sendo possível individualizar quatro zonas distintas no seu seio (Fig. 5):

- Zona A $\left(1.150 \mathrm{~m}^{2}\right)$, que prolonga para sul e para nascente a área intervencionada no ano 2000, caracterizada pela nitidez dos seus limites. Esta zona é relativamente uniforme, correspondendo a elevadas densidades de cerâmica, conjugada com algumas densidades medianas. A intervenção arqueológica da sondagem 3 e da sondagem 6 poderá constituir um factor de distorção da densidade nos quadrados situados nas proximidades da área não prospectada (áreas sondadas, espaço limítrofe destas sondagens e depósitos das terras provenientes desta escavação num total de $500 \mathrm{~m}^{2}$ ). Com efeito, verifica-se uma quebra significativa das densidades de cerâmica na orla imediata dessas sondagens, o que não era de esperar dado que se trata seguramente de uma área edificada. Os limites desta zona são nítidos na área setentrional do seu perímetro e difusos nas restantes áreas.

- Zona B $\left(1.600 \mathrm{~m}^{2}\right)$, situada imediatamente para SE, mas separada por uma fina faixa de densidades medianas. Esta zona caracteriza-se pela sua uniformidade e pela nitidez dos seus limites, correspondendo exclusivamente a elevadas densidades de cerâmica.

- Zona $\mathrm{C}\left(1.650 \mathrm{~m}^{2}\right)$, contígua à zona $\mathrm{B}$ e desenvolvendo-se para poente desta última. É bastante homogénea, sendo constituída por densidades medianas com alguns "picos" isolados de concentrações elevadas. Apresenta limites difusos. 
- Zona D (13.370 $\left.\mathrm{m}^{2}\right)$, situada para nascente da zona A, correspondendo a uma nuvem rarefeita de pequenas manchas apresentando densidades pouco significativas. $O$ carácter pontual desta zona torna os seus limites difusos.

De forma a comparar o tipo de espólio observado adentro de cada uma destas zonas, efectuou-se uma pesquisa espacial no Arcview, procurando-se seleccionar os atributos de todos os quadrados prospectados. Foi de seguida gerado um resumo estatístico dos atributos relativos ao material registado, que foi exportado para o programa Excel onde se calculou a percentagem que os diferentes tipos de materiais apresentavam em cada zona (Gráfico 3).

Foi assim possível evidenciar algumas diferenças significativas na distribuição percentual de certos tipos entre as diferentes zonas, que poderão ajudar a caracterizá-las melhor. A relação percentual dos tipos de materiais observados nas zona $\mathrm{A}$ e $\mathrm{C}$ é bastante próxima; a cerâmica de construção representa cerca de $90 \%$ do total; a cerâmica de mesa e de armazenamento equiparam-se rondando os $4,5 \%$ enquanto que os restantes materiais são residuais ou nulos. Na zona B, verificam-se relações percentuais bastante próximas daquelas verificadas nas zonas A e $\mathrm{C}$, distinguindo-se apenas pelo facto de a cerâmica de mesa $(2,31 \%)$ estar sub-representada em relação à cerâmica de armazenamento $(4,72 \%)$ e da escória apresentar uma percentagem sensivelmente mais elevada $(0,16 \%$ contra 0,06 na zona A e 0,09 na zona C). A zona D tem características nitidamente distintas das três primeiras; em primeiro lugar, a percentagem de minério é cerca de 14 vezes superior à das restantes zonas7; igual fenómeno verifica-se em relação à cerâmica de mesa (entre 3 a 6 vezes superior), à escória (entre 3 a 7 vezes superior) e aos pesos de tear; estes aumentos relativos reflectem-se inevitavelmente na sub-representação da cerâmica de construção (cerca de 68\%).

A topografia pode distorcer fortemente os resultados de uma prospecção intensiva (GERRARD, 1995: 138-140). Por este motivo será conveniente analisar o impacte deste factor na delimitação das zonas de concentrações de materiais.

A observação das Figuras 3 e 6 permite verificar que o declive é bastante uniforme em toda a área de estudo, exceptuando no sector L,

7 Algumas amostras recolhidas durante a prospecção foram posteriormente identificadas - por Fernando de Almeida (Dep. Geociências da Univ. Aveiro) - como sendo hematite. 
onde se acentua. De um modo geral, a área de estudo enquadra-se numa vertente orientada NO/SE - verificando-se para NO as cotas mais elevadas - sendo desta forma razoável esperar um deslocamento preferencial do material em função dessa orientação, o que significa que as densidades observadas nas áreas limítrofes para SE dentro das zonas anteriormente definidas poderão estar exageradas devido a este fenómeno.

Por outro lado, a observação do declive reforça também a ideia das zonas A e B serem duas áreas bem distintas, apesar de ambas serem constituídas por concentrações elevadas de materiais. Com efeito, a zona A é separada da zona B por um corredor com cerca de 10/15m de largura com concentrações menos significativas de materiais (Fig. 4 e 5). Se as densidades elevadas verificadas na zona B, situada num plano mais baixo, resultassem de um deslocamento proveniente da zona A, situado a uma cota mais alta para NO, este corredor não existiria, uma vez que a intensidade do declive pouco varia em toda esta área. Por outro lado, a vizinhança da zona $\mathrm{C}$ em relação à zona $\mathrm{B}$ também não se pode explicar por deslocações de materiais devido à gravidade porque a orientação do declive não favorece o deslocamento de material de uma zona para outra. A mesma observação é pertinente relativamente à vizinhança da zona D com a zona A (Fig. 6 e 7).

De um modo geral, pode-se concluir que a topografia da área de estudo não deve estar na origem da organização espacial interna da mancha de dispersão de materiais, embora se admita que haja um deslocamento generalizado do material de NO para SE, que será pouco significativo e regular uma vez que o declive de toda esta área é suave e quase constante.

\subsection{Prospecção geomagnética}

De uma forma genérica, uma anomalia define-se pela sua diferença em relação a uma norma. A análise de qualquer anomalia não faz por este motivo qualquer sentido sem a análise do seu contexto. No caso em estudo, o mapeamento geomagnético não apresenta uma textura homogénea em toda a área de estudo. Se omitirmos as anomalias pontuais e lineares, é possível distinguir três grandes zonas de gradiente (Fig. 8):

Zona 1: esta zona caracteriza-se pela homogeneidade dos gradientes registados que se traduz por uma textura da mancha de cinzen- 
tos bastante homogénea que ocupa grande parte da área de estudo; para norte, esta zona caracteriza-se por uma textura "penteada", com orientação SE/NO, correspondendo a ínfimas variações do gradiente, certamente provocadas pela recente lavra do terreno;

Zona 2: esta zona (sector $\mathrm{K}$ e metade $\mathrm{E}$ do sector $\mathrm{J}$ ) caracteriza-se pela heterogeneidade mediana dos gradientes registados, que se traduz por uma textura heterogénea da imagem com leves variações de tonalidades de cinzento;

Zona 3: esta zona, com uma área bastante restrita (metade meridional do sector $\mathrm{G}$ ), caracteriza-se pela heterogeneidade acentuada dos gradientes, que se traduz por uma textura heterogénea da imagem com variações abruptas de tonalidades de cinzento, geralmente estruturados em alinhamentos descontínuos com orientação sensivelmente E/O; esta zona corresponde em grande parte a uma área de giestal - registada no levantamento topográfico - que tinha sido desmatada através do fogo de modo a facilitar a circulação dos rebanhos de ovinos que costumam pastar nesta área; esta acção traduziu-se na acumulação de quantidades apreciáveis de cinzas e carvões nas depressões dos micro-relevos que a caracterizam, podendo estar na origem das anomalias magnéticas aí registadas.

Após se terem isolado as anomalias que se ficavam a dever claramente ao ruído, definiram-se quatro grandes classes de anomalias em função da sua intensidade e da sua configuração espacial (Fig. 9):

Classe $\mathrm{A}$ - anomalias lineares com variações do gradiente suaves (-4/6nT) e medianas (-20/20nT); entre elas distinguem-se dois conjuntos:

- A1 e A2, que correspondem a dois alinhamentos quase rectilíneos, observados no limite entre os sectores $\mathrm{D}$ e $\mathrm{F}$, com orientação sensivelmente NO/SE e paralelos entre eles, com variações de gradiente muito suaves;

- A3, A4, A5 e A6, que correspondem a linhas curvas com orientação sensivelmente NO/SE (exclusivamente representadas no sector B), com variações de gradiente suaves ou medianas (-20/20nT), podendo entroncar umas nas outras (A3 e A4) e parecendo formar uma estrutura tendencialmente ramiforme.

Classe B - anomalias pontuais com variações de gradiente medianas $(-20 / 20 n T)$ que aparecem geralmente inseridas em concentrações espalhadas por toda a metade NE da área de estudo (B4 à B33), aparecendo por vezes isoladas na área meridional (B1, B2, B3).

Classe $\mathrm{C}$ - anomalias pontuais com variações importantes de gradiente $(-500 / 500 \mathrm{nT})$ que são mais frequentes na metade NE da área de 
estudo (C2, C3, C4 e C5) (a anomalia C1 encontrando-se isolada próximo do canto SO do sector $\mathrm{L}$ ).

Classe D - anomalia complexa, tendencialmente linear, com orientação sensivelmente $\mathrm{SO} / \mathrm{NE}$, com variações de gradiente medianas, localmente importantes, atravessando a metade norte dos sectores $\mathrm{F}$ e G; para oriente, os valores negativos da anomalia encontram-se para sul dos valores positivos, o que é bastante invulgar nesta latitude.

De modo a afinar a classificação das anomalias elaborada com base no mapeamento geomagnético, procedeu-se a uma análise quantitativa individual de cada anomalia como forma de avaliar a sua profundidade. No Excel, elaborou-se para este efeito um perfil de gradientes com orientação N/S para cada anomalia, atravessando o seu centro e abrangendo toda a área afectada por ela (Tabela 1). Os dados usados para este fim merecerem apenas um tratamento de erros geométricos de forma a minimizar o impacte do "alisamento" dos valores derivados da aplicação de filtros.

Para cada tri-nome (x, y, gradiente) do perfil, procedeu-se à inversão da curva das medições, ajustada segundo o modelo teórico de um dipolo provocado por um corpo esférico (AlmEIDA et alii, no prelo). Nos casos onde se verificou que a tendência dos valores normais de gradiente se afastava de forma significativa de $0 \mathrm{nT} / \mathrm{m}$, subtraiu-se a diferença em relação à $0 \mathrm{nT} / \mathrm{m}$ a cada gradiente do perfil. De facto, a aplicação deste modelo pressupõe que a tendência normal dos gradientes medidos seja próxima de $0 \mathrm{nT} / \mathrm{m}$. De forma a aferir a qualidade da aproximação ao modelo teórico, calculou-se ainda a diferença quadrática média entre gradientes observados e gradientes teóricos, rejeitando diferenças superiores a 10. Desta forma, não foi possível efectuar a quantificação da abcissa e da profundidade das anomalias A1, A2, A3, A4, A5, A6, B13, B15, B16, B26, B33, C1 e C4. Em alguns casos, as elevadas diferenças quadráticas observadas ficarão decerto a dever-se ao facto dessas anomalias não apresentarem características dipolares, enquanto que, noutros casos, resultarão do facto de se encontrarem ocultadas pela influência de outras anomalias relativamente próximas. Convém ainda referir que os resultados da aplicação deste modelo à anomalia D (D', D", D"') - de carácter linear - devem ser usados com as devidas reservas, uma vez que o modelo foi concebido para caracterizar anomalias dipolares. Os resultados desta abordagem quantitativa são apresentados na Tabela 1 .

As profundidades estimadas para os pólos negativos e positivos nunca ultrapassam $1,25 \mathrm{~m}$. A maior parte das ocorrências verifica-se na 
verdade entre 0,5 e 1m de profundidade. Duas anomalias, B21 e C5, poderão ser provocadas por artefactos ferrosos de pequenas dimensões presentes à superfície ou na camada sob a superfície do solo. Assim o deixa entender o facto da distância horizontal entre o pólo positivo e negativo ser quase nula, a par com o facto de se encontrarem bem perto da superfície. De uma forma geral, os resultados desta análise deixam entender que, salvo as excepções acima referidas, a contaminação da superfície da área de estudo por artefactos metálicos é mínima, devendose procurar a explicação da maior parte das anomalias nos horizontes pedológicos e nos níveis mais superficiais do substrato rochoso.

\subsection{Sondagens de controle}

Em quase todas as sondagens foi possível verificar a existência de um solo pedologicamente evoluído, estando apenas ausente os horizontes $\mathrm{O} 1$ (manto de folhas) e $\mathrm{O} 2$ (detritos orgânicos formados em condições de saturação de água) devido aos trabalhos de lavoura que o rasgam regularmente à superfície. O solo mineral de superfície, caracterizado pela acumulação de matéria orgânica vegetal (horizonte A1), de cor castanha escura, algo acinzentada (UE 01 em todas as sondagens), encontra-se assim directamente exposto às intempéries (BUTZER, 1989: 122).

As estratigrafias observadas nas 5 sondagens de controle efectuadas podem ser agrupadas em três fases.

A fase 1, representada em todas as sondagens, é constituída pelas terras da base do perfil pedológico, parecendo enquadrar-se nos horizontes minerais do solo de tipo $\mathrm{B}$ e excepcionalmente de tipo $\mathrm{C}$ (neste último caso, trata-se de horizontes pouco influenciados pela pedogénese, como será o caso da UE 08 da sond. 7). A formação destes estratos, onde não foi recolhido qualquer tipo de arqueofacto, parece ser anterior à ocupação antrópica do sítio.

A fase 2 é em grande parte constituída por unidades estratigráficas que cortam sempre aquelas que pertencem à fase anterior, documentando actividades antrópicas que implicaram a escavação do solo da altura através da abertura de fossas e valas. Infelizmente, não se recolheram quaisquer artefactos nas UE's desta fase. Registe-se que esta fase não se encontra representada na sondagem 4 e na metade da sondagem 5 que foi objecto de escavação integral. 
Finalmente, a fase 3, formada por terras do horizonte A, documenta o encobrimento ou enterramento do paleossolo e do respectivo nível (ou níveis ?) de circulação da fase 2 , constituindo uma capa de sedimento que atinge regra geral cerca de 0,3 a $0,6 \mathrm{~m}$. Os declives nulos, suaves e moderados que predominam em toda a área de estudo, a par com a sua posição a meia encosta do sistema bacia / vertente do vale do Zêzere, terão sempre favorecido os processos sedimentares em detrimento da erosão (BICHET et alii, 1997: 25-34). Os materiais de cronologia romana observados em prospecção provêm destes estratos compostos por solos minerais de superfície. O seu deslocamento até ao topo do solo actual deve-se a um conjunto de factores pós-deposicionais, destacando-se o papel das lavras que provocam regularmente um remeximento do solo de superfície em toda a área, sendo igualmente admissível que alguns deslocamentos verticais de materiais se fiquem a dever à acção do gelo (BUTZER, 1989: 101), tendo em consideração o rigor do clima desta região no Inverno.

Em escavação, a completa ausência de materiais arqueológicos nas UEs da fase 2 só nos permitiram estabelecer uma cronologia relativa de formação para os depósitos e elementos interfaciais. A presença exclusiva de materiais romanos nas UEs da fase 3 permitem-nos, todavia, fixar no período romano um terminus post quem para esta fase, marcando o interface superior da fase 2 um limite abaixo do qual as UEs se devem inscrever nesse mesmo período ou numa época ainda mais recuada.

Segue-se uma descrição individual dos resultados de cada sondagem, com particular incidência sobre as estruturas antrópicas que integram a fase 2:

\section{Sondagem 1}

O objectivo específico da escavação desta sondagem consistia no apuramento da causa das anomalias geomagnéticas de classe B - designadamente das anomalias B13 e B14 - que, nesta área, surgem em quantidade assinalável e concentradas (Fig. 3, 8 e 9).

A intervenção da sondagem 1 permitiu verificar que essas anomalias foram provocadas, respectivamente, pela UE 07 (depósito) e pela UE 13 (elemento interfacial que configura uma fossa) preenchida pelas UEs 05 e 12 (depósitos). Ambos os casos constituem aglomerações de películas descontínuas de terras escuras e avermelhadas, impregnadas por manchas de cinzas e pontos de carvão, surgindo por vezes pequenos calhaus com evidências de terem sofrido a acção do fogo. Estas carac- 
terísticas, conjugadas com a configuração que aparentemente assumiam - em forma de pequena bolsa (no caso do depósito / UE 12) ou formando uma fossa escavada até ao substrato (no caso dos depósitos / UEs 05 e 12) $-^{8}$, sugeriram, desde logo, a hipótese destas corresponderem a estruturas de combustão, relacionadas, eventualmente, com a metalurgia (Fig. 10 e Foto 5). Com efeito, os sedimentos que preenchiam estas "fossas" escavadas no sub-solo faziam lembrar os agregados resultantes de combustões, uma vez que estes costumam formar interdigitações lenticulares, que oferecem várias gradações entre partículas de cinza, de argila cozida amarela ou vermelha e agregados carbonáceos escuros (BUTZER, 1989: 81), remetendo também, de alguma forma, para os fornos rudimentares em cova que - de modo a executarem a operação inicial de redução do minério - eram preenchidos, nas proporções adequadas, com cargas misturadas ou alternadas de carvão e mineral triturado (GómEZ RAMOS, 1999).

Independentemente da sua atribuição funcional, em termos da sua composição física e do seu posicionamento espacial e estratigráfico, estas estruturas eram perfeitamente individualizáveis em escavação, tendo surgido apenas alguns problemas ao nível da identificação da "fossa" preenchida pelos depósitos 05 e 12. Com efeito, uma observação mais atenta das características e limites destas UEs levou-nos a colocar a hipótese destas documentarem duas acções semelhantes - abertura / preenchimento de uma fossa - mas distintas no tempo - ainda que imediatamente se sucedessem. Se assim fosse, o elemento interfacial 13 documentaria a abertura de uma primeira fossa - preenchida depois pelo depósito 12 - enquanto que o elemento interfacial 05 -a registaria a abertura (ou reabertura) de uma segunda fossa menos profunda e localizada sensivelmente no mesmo local do que a anterior - sendo posteriormente preenchida pelo depósito 05 . Pelo facto da linha que as configura se iniciar a partir da mesma superfície de circulação antiga, estas - ainda que se sucedessem imediatamente no tempo - inscrever-se-iam no mesmo horizonte cronológico9 ${ }^{9}$. Todavia, as diferenças detectadas,

8 A sua topologia não pode, nesta fase, ser mais especificada, uma vez que estas estruturas se encontram parcialmente inseridas no corte poente da sondagem.

9 Esta suposição poderia ser negada se existissem indícios de truncamento da parte superior destas estruturas; não é, porém, este o caso, uma vez que encontrámos uma pequena aglomeração de pedras - algumas com vestígios nítidos da acção do fogo - incrustadas na parte superior da UE 05. 
designadamente na cor destes dois tipos de enchimento, poderão antes ficar a dever-se a processos de pedogénese - de natureza físico-química - com características e ritmos distintos, ainda que contínuos no tempo.

Próximo destas "fossas" identificou-se uma outra estrutura em negativo que interpretámos como possível "buraco de poste" [UEs 06 / / 10] (Fig. 10 e Foto 6). Este será contemporâneo das estruturas antes referidas e daquela que descreveremos de seguida, uma vez que também aqui é possível verificar que a linha de corte ou que configura todas estas estruturas arranca a partir do mesmo nível de circulação antigo.

Ao longo do corte nascente, registou-se um outro elemento interfacial que configura uma "vala" [UE 09], preenchida por uma bolsa de calhaus de quartzo de fractura angulosa [UE 04], que dada a sua localização parece ter sido aberta com o intuito de desbastar ou explorar um veio quartzítico que se encontra exclusivamente neste local (Fig. 10 e Foto 5-6). Duas amostras de calhaus, uma recolhida nesta UE 04, e outra no filão quartzítico do substrato, foram submetidas a uma análise macroscópica - efectuada por Fernando Pedro Figueiredo e Lídia Catarino -, tendo-se constatado que, em ambos os casos, se tratava de elementos brechóides contendo aglomerações substanciais de óxido de ferro não magnético, o que de algum modo veio reforçar a hipótese do referido depósito [UE 04] resultar da escavação desse mesmo veio de quartzo. Este último insere-se num conjunto mais vasto documentado na Carta Geológica, que forma uma densa rede de filões, por vezes muito extensos (até $3 \mathrm{~km}$ de cumprimento), com orientação sensivelmente $\mathrm{SO} / \mathrm{NE}$ e paralelos entre eles. Estes filões mostram-se por vezes brechóides, como é aqui o caso, com aglutinação dos fragmentos por silificação posterior às acções que os tectonizaram (TEIXEIRA et alii, 1974: 43).

Apesar de não ser rentável para os padrões actuais ${ }^{10}$, a exploração mineira de filões quartzíticos pode entender-se como uma actividade doméstica relativamente habitual no quadro da economia antiga. Com efeito, a frequência de achados à superfície de escória de ferro em grande parte dos estabelecimentos rurais romanos de todo o país - tal como também acontece em "Terlamonte I" - parece sugerir a existência

10 A análise química de uma amostra de rocha/minério à mistura com solo proveniente deste filão, efectuada pelo método ICP-AES, revelou um teor em ferro de $15,63 \%$. Os valores medidos para os outros tipos de metais analisados como o cobre (18 ppm), o chumbo $(7 \mathrm{ppm})$, a prata $(<0.3 \mathrm{ppm})$ ou o ouro $(<2 \mathrm{ppm})$ são meramente residuais. 
de explorações de pequena escala - geograficamente muito difundidas - de jazidas superficiais de ferro (AlARCÃO, 1988: 132)11. Alarcão (1988: 133) sugere ainda que a extracção e a fundição seriam efectuados pelo próprio ferreiro, que providenciaria os utensílios necessários ao consumo local, sendo a sua comercialização extremamente reduzida, uma vez que muitas villae e vici dispunham de ferrarias próprias. Com efeito, parece-nos igualmente verosímil que em estabelecimentos rurais mais modestos, de carácter familiar e com uma menor projecção económica, o proprietário da exploração assumisse directamente o encargo e a função de extrair o minério, de reduzir e de produzir os instrumentos necessários ao desempenho da sua actividade. As prospecções levadas a cabo na Cova da Beira, têm registado restos de fundição em sítios que podem ser classificados como casais ou quintas, sugerindo, assim, que também neste tipo de núcleos rurais a actividade metalúrgica fosse relativamente recorrente, reforçando de algum modo o carácter "autosuficiente" de muitos destes pequenos núcleos.

À semelhança do que se verifica noutras regiões durante a época romana - nomeadamente na Serra da Malcata, bem próxima do sítio em análise (LEMOS e REI, 2000: 90) - parece-nos admissível que se tenham aqui explorado também - a uma escala familiar - filões quartzíticos. A redução inicial do minério poderia ser feita - segundo modos ancestrais - no próprio local da extracção - evitando-se assim o transporte do minério em bruto para uma zona de redução mais afastada - construindo-se para isso fornos muito rudimentares, em parte escavados no solo, os quais eram desfeitos e reescavados no final de cada operação para retirar a escória solidificada e os minerais parcialmente fundidos que, dada a sua maior densidade, se encontravam depositados no fundo (Sim, 1998: p. 7 e ss e Gómez Ramos, 1999).

É neste quadro interpretativo que poderemos, por enquanto, inserir as 'UEs negativas' registadas nesta sondagem. Num trabalho anterior, tinhamos já formulado a hipótese da formação da referida "vala" se ficar a dever à extracção dos óxidos de ferro contidos nesse veio quart-

11 Registe-se, a este propósito, que Plínio faz referência ao facto de o ferro ser o mais frequente de todos os minérios metálicos da Península Ibérica, não obstante parecerem ser raros os sítios onde esta produção tivesse sido feita em larga escala (DoMERGUE, 1990: 78). Na região em análise, por exemplo, apenas se documentam vestígios de exploração do ferro com algum significado nas zonas de Marmeleiro, Pousafoles do Bispo e Cabeço das Fráguas (AlARCÃo, 1988: 133).

Conimbriga, 43 (2004) 99-147 
zítico (Silva e CARVAlHo, no prelo). Nas imediações desse filão objecto de exploração situar-se-iam, por sua vez, os fornos redutores em cova aqui representados pelas "fossas" anteriormente descritas. A ser assim, "Terlamonte I", que apresenta ainda os restos do que julgamos ser uma pequena forja junto à área edificada, constituiria um exemplo de um núcleo rural de médias dimensões que - também a este nível - procurava ser auto-suficiente, congregando assim o essencial das práticas que conferiam à família que nele habitava, em termos de subsistência, uma relativa autonomia.

Este cenário que traçámos, todavia, não pode deixar de ser questionado, como veremos, em função dos dados de natureza cronológica que obtivemos algum tempo após a conclusão dos trabalhos de campo.

\section{Sondagem 2}

Com a abertura da sondagem 2 procurava-se identificar o que originava uma outra anomalia do tipo B - a anomalia B5 - caracterizada pelo facto de apresentar, juntamente com a anomalia B6 que lhe é adjacente, um maior desenvolvimento espacial (Fig. 3, 8 e 9). Pretendia-se assim, observar se esta variação do tamanho da anomalia era provocada por estruturas distintas daquelas representadas pelas restantes anomalias da classe B ou se eram antes originadas por estruturas do mesmo tipo (ainda que de maiores dimensões ou soterradas a maior profundidade).

Com o decorrer da escavação, verificou-se que esta anomalia era provocada por uma estrutura de combustão (Fig. 11 e Fotos 7 e 8) que se materializava numa fossa [UE 04], cujo enchimento [UE 03] apresentava similitudes com os enchimentos das estruturas 1 e 2 anteriormente referidas. Todavia, distinguia-se destes, desde logo, pelo carácter claramente lenticular das numerosas bolsas de cinzas e carvões e de terras avermelhadas e acastanhadas que a constituíam - formando um típico 'perfil de equilíbrio' - e pelo facto de apresentar uma amplitude consideravelmente maior - apesar de não ser abrangida na totalidade pela sondagem 2, esta estrutura terá sempre mais de 3,60 m de diâmetro e $1 \mathrm{~m}$ de profundidade, sendo em grande parte escavada no substrato. Pelas suas características, parece poder comparar-se com a fossa detectada no pátio do sítio romano da Quinta da Fórnea (Belmonte) - também interpretada como área de fundição -, uma vez que esta apresenta um diâmetro em torno dos $6 \mathrm{~m}$ e uma planta sub-circular, sendo preenchida por uma camada de pedras e muitos fragmentos de cerâ- 
mica, observando-se ainda no seu topo uma grande quantidade de escória de ferro e de cinzas (BERNARDES et alii, 1999: 90) ${ }^{12}$.

A possibilidade da estrutura que identificámos poder também ser interpretada como área de fundição parece ser de alguma forma corroborada pela identificação - na sua margem e centro - do negativo de três buracos - com cerca de 0.10/0.15 m de diâmetro - que cruzavam o enchimento da fossa num ângulo de inclinação em torno dos 25-30. ${ }^{\circ}$ [UEs 05/06, 07/08 e 09/10] (Fig. 11 e Foto 8) e que poderiam corresponder às respectivas entradas de ar. Ainda que estejam arqueologicamente mal documentados - quer porque se situariam afastados das áreas residenciais habitualmente escavadas, quer porque seriam em parte destruídos após a sua utilização -, é sabido que este tipo rudimentar de fornos redutores escavados no solo teriam que ser adequadamente arejados, uma vez que o oxigénio é absolutamente fundamental para viabilizar qualquer processo de combustão; esta ventilação conseguia-se através da abertura de buracos em determinados pontos da câmara, insuflando-se assim para o seu interior - recorrendo-se a foles de peles - o ar necessário a partir de tubagens de natureza orgânica, como sejam as canas e os juncos vegetais (Gómez RAMOs, 1999).

\section{Sondagem 4}

Com a intervenção da sondagem 4 pretendia-se documentar as anomalias magnéticas de tipo $\mathrm{C}$, concretamente através da escavação da anomalia C2 (Fig. 3, 8 e 9). A escavação registou o carácter geológico da estrutura correspondente, tratando-se de um fino veio de argila de cor castanha-alaranjada [UE 03] que atravessa a sondagem de SO para NE, preenchendo uma falha do substrato granítico (Fig. 12 e Foto 9). A elevada concentração em óxidos de ferro que caracteriza a argila ${ }^{13}$, asso-

12 A manifesta ausência de escórias na superfície da estrutura que identificámos constitui uma diferença fundamental relativamente ao que foi registado na Quinta da Fórnea; porém, a configuração linear e horizontal do interface superior que marca o início da sequência estratigráfica da fase 2 e o seu contacto imediato com a camada arável de superfície, leva-nos a considerar a possibilidade do topo desta fossa ter sido truncado, podendo com esse processo terem desaparecido os possíveis restos de fundição que se encontrassem ainda à superfície.

13 A análise química de uma amostra de sedimento proveniente desta UE, efectuada pelo método ICP-AES, revelou um teor em ferro $(5,25 \%)$ cerca de duas vezes superior àquele medido nas restantes amostras de sedimento analisadas até esta data, cujo teor em ferro varia entre os 2,6 e $3,6 \%$. 
ciada ao carácter delgado do depósito subjacente [UE 01], estará provavelmente na origem desta anomalia.

\section{Sondagem 5}

A sondagem 5 tinha como finalidade apurar a causa das anomalias de tipo A, com base na intervenção da anomalia A2 (Fig. 3, 8 e 9). Pretendia-se igualmente verificar se existia uma relação entre esta anomalia e um muro de limite de propriedade - com orientação NO/SE - posto a descoberto pelos trabalhos de desmatação, uma vez que a referida anomalia lhe era sensivelmente paralela, distando apenas alguns metros para nascente. Infelizmente, não foi possível concluir a escavação desta sondagem - e intervencionar concretamente a área onde se verificava a anomalia - até ao final do prazo que para o efeito tinha sido estipulado. Esta intervenção, todavia, permitiu verificar que o muro acima referido estava completamente desmantelado nesta área, identificando-se apenas o seu derrube [UE 02] (Fig. 13 e Foto 10). A ocorrência desta UE no depósito superficial integrável na fase 1 sugere a posterioridade da sua formação relativamente à ocupação romana do sítio.

\section{Sondagem 7}

A determinação da causa da anomalia $\mathrm{D}$ era o objectivo assumido da intervenção da sondagem 7 , a única efectuada no interior das principais áreas de dispersão de materiais arqueológicos à superfície e precisamente sobre uma anomalia que no mapeamento geomagnético se caracterizava por se estender de forma contínua ao longo de várias dezenas de metros e onde os valores negativos se verificavam para sul dos valores positivos (Fig. 3 e 9). O respeito forçado pelos prazos definidos para os trabalhos de campo impossibilitou a intervenção da metade meridional desta sondagem, permitindo, no entanto, identificar a origem da anomalia. Trata-se de um depósito siltoso - localizado na parte sul da sondagem - de coloração quase negra [UE 04], envolvendo um depósito de idêntica granulometria e distinguindo-se do anterior pela sua coloração bege amarelada [UE 05] (Fig. 14 e Foto 11). As partículas extremamente finas que o constituem (siltes) - nunca identificadas nas restantes sequências estratigráficas registadas - parecem remeter para contextos de circulação e/ou estagnação de água. Se conjugarmos esta textura característica com a configuração da estrutura em negativo onde este depósito se encontra inserido [UE 06], parece-nos aceitável poder interpretá-lo como o enchimento duma vala pela qual terá corrido água. 
Recentemente, foi possível prolongar um pouco mais a sondagem 7 para sul (abrindo-se uma sond. $2 \times 2 \mathrm{~m}$ ), tendo-se registado a continuidade da mesma estrutura e identificado no seu interior um amontoado de material geológico que parece corresponder a ilmenite.

\section{Interpretação global}

O cruzamento de todos os dados cotejados permite tecer algumas considerações acerca da ocupação do espaço por parte dos habitantes da quinta romana de "Terlamonte I".

Desde logo, os resultados da prospecção intensiva apontavam para o carácter relativamente modesto - em termos de classificação tipológica - do estabelecimento rural em estudo. Este, em função destes dados, parecia ocupar uma área bem inferior aos $1.650 \mathrm{~m}^{2}$ ocupados pela zona A $\left(1.150 \mathrm{~m}^{2}\right)$ e pela área imediatamente envolvente à zona intervencionada que não foi prospectada $\left(500 \mathrm{~m}^{2}\right)$, uma vez que, ao desenvolver-se para sul dos compartimentos já descobertos, a Zona A poderia em parte ser o resultado da degradação gradual das estruturas que sobressaíam originalmente do topo do solo (Fig. 4, 5 e 15). De facto, dado a orientação geral do declive nesta área tendencialmente para SE, a deslocação por gravidade do material derivado da sua degradação poderá ter-se acentuado nesta direcção. Seja como for, mesmo que somássemos a estes $1.650 \mathrm{~m}^{2}$ os $1.600 \mathrm{~m}^{2}$ ocupados pela área $\mathrm{B}$, igualmente caracterizada por elevadas concentrações de cerâmica, atingir-se-iam apenas os $3.250 \mathrm{~m} 2$, continuando este valor a ser manifestamente insuficiente para classificar este assentamento como villa, se adoptássemos o critério da área de dispersão - definido para este tipo de sítios entre os 5.000 e os $25.000 \mathrm{~m} 2$ - proposto por Alarcão (1998: 95).

Este mesmo critério é seguido, genericamente, em trabalhos recentes sobre o povoamento rural romano efectuados na Beira Interior, designadamente nas bacias da Ribeira de Massueime (PERESTRElo e FERrEIRA, 2000: 100) e do Alto Côa (OsórIo, 2000: 85), notando-se inclusivamente uma tendência, por parte destes autores, em fixar o limite mínimo da área de dispersão de materiais das villae em torno dos $10.000 \mathrm{~m} 2$. A comparação, no entanto, da área de dispersão definida no quadro deste estudo com aquelas estimadas empiricamente pelos processos de investigação acima referidos pode levantar alguns problemas, devido ao facto das duas abordagens seguirem metodologias distintas. 
De qualquer forma, a monotonia do material observado através da prospecção de superfície por quadriculagem em "Terlamonte I" - evidenciando um fraca expressão sob o ponto de vista qualitativo - não permitia a sua classificação como villa, sugerindo poder tratar-se antes de uma quinta ou granja, centrando-se o seu espaço construído exclusivamente na zona A. Neste ponto, convém sublinhar que se entende por quinta ou granja uma exploração agrícola de média dimensão, com habitações mais modestas do que uma villa (AlARCÃO, 1998: 92). Mas esta menor amplitude, em termos de áreas edificadas e exploradas, não impediria que as quintas pudessem de algum modo desempenhar nestas regiões interiores da província da Lusitânia, o papel fulcral que as villae assumiam - ao nível da ocupação e exploração do espaço rural noutras regiões mais meridionais ou costeiras (CARVALHO et alii, 2002).

Esta proposta inicial de classificação tipológica foi corroborada pelas escavações que ultimamente se fizeram no local, assim como também de algum modo foi confirmada a estimativa inicialmente avançada para a amplitude do seu espaço edificado com base nos resultados da prospecção de superfície em quadrícula. Com efeito, de acordo com os elementos até ao momento recolhidos, a área telhada desta granja rondará provavelmente os $700 \mathrm{~m}^{2}$, podendo atingir os $1.050 \mathrm{~m}^{2}$ se contabilizarmos também os espaços interiores descobertos, ficando assim aquém dos $1.650 \mathrm{~m}^{2}$ anteriormente referidos.

Recentes escavações permitiram igualmente confirmar uma proposta surgida da análise do mapeamento geomagnético: a anomalia A1, de formato linear e prolongando cerca de $15 \mathrm{~m}$ para SE um dos muros inicialmente identificado na sondagem 3 , corresponde mesmo a uma parede relativamente extensa que parece constituir o limite nordeste da área edificada (Fig. 9 e 15).

Como já foi dito, a área edificada deste assentamento não ocuparia a totalidade da zona $\mathrm{A}$. A sua metade meridional, frente à fachada principal do edifício, poderá ter constituído uma área preferencial de actividade, a qual não foi possível individualizar no mapeamento das concentrações de materiais pelo facto de se encontrar certamente encoberta pelo deslocamento por gravidade dos materiais provenientes da degradação do edifício (sobre o conceito de área preferencial de actividade: Silva e SiLVA, no prelo). Tratando-se de um espaço exterior contíguo à área habitacional - encontrando-se imediatamente em frente à sua fachada principal - parece-nos previsível que fosse o palco de numerosas actividades quotidianas. A presença da estrutura correspondente à ano- 
malia geomagnética D (Fig. 9) pode talvez relacionar-se com alguma dessas actividades, tratando-se à primeira vista - dada a sua configuração e composição - de uma extensa vala preenchida com sedimentos muito finos resultantes do transporte por água. A implantação desta anomalia no mapa dos declives permitia desde logo verificar, de forma inegável, o carácter antrópico desta estrutura, uma vez que a sua orientação (SOO/NEE) diverge significativamente da orientação dos declives envolventes (NO/SE). A estimação da profundidade dos três perfis D' D" e D" permite também constatar que se trata de uma anomalia consideravelmente funda e larga - com mais de $0,7 \mathrm{~m}$ a $1,4 \mathrm{~m}$ de profundidade e com mais de $2 \mathrm{~m}$ a 2,5 m de largura em $\mathrm{D}^{\prime}$ e $\mathrm{D}^{\prime \prime}$ ), perdendo expressão à medida que se afasta da área habitacional (de 0,7 a 0,9 m de profundidade em D"' e $0,3 \mathrm{~m}$ de largura)(Tabela 1 ). No mapeamento verifica-se ainda que esta anomalia se atenua junto a uma linha de drenagem (Fig. 9 e 15), sendo talvez esse o destino das águas transportadas através desta vala, uma vez que o local onde essa linha é intersectada pela vala se encontra a uma cota mais baixa em relação ao início desta. Em termos de escavação, recorde-se que a sondagem 7 permitiu, essencialmente, confirmar em termos físicos a presença desta vala, não tendo sido possível até ao momento identificar a sua exacta funcionalidade.

A divisão entre esta área preferencial de actividade - ou pátio - e as áreas envolventes é bem visível no mapa das densidades de materiais (Fig. 4, 5 e 15). Para NE, o limite entre a zona A e a zona D é bem nítido, correspondendo a uma quebra súbita das densidades de material ao longo de um alinhamento com orientação NO/SE. A discriminação do material observado reforça a ideia deste limite marcar a divisão entre espaços bem distintos, uma vez que o material de construção se encontra aí bastante menos representado do que nas restantes áreas (apenas 68\% do material registado, enquanto que em toda a área de estudo representa $90 \%$ ). Este alinhamento - que marca uma divisão entre diferentes áreas - coincide em grande parte com um murete ainda bem visível, formado por pedras de média dimensão toscamente talhadas, e que não constitui nenhum limite de propriedade actual (Fig. 3). À partida, poderíamos pensar que este poderia de alguma forma encontrar-se relacionado com a ocupação romana do local, mas os resultados da intervenção da sondagem 5 parecem sugerir a sua integração numa fase muito posterior a esta ocupação. Sublinhe-se, porém, que a anomalia linear A2, com uma orientação muito similar à dos muros do edifício, fica a alguns metros de distância para NE deste murete e com uma orientação ou ali- 
nhamento muito próximos. Pode-se assim colocar a hipótese de se verificar aqui um fenómeno de isoclinação (CHOUQuER, 1997: 20), dado o tipo de laços relacionais que parecem estabelecer-se entre a estrutura que se observa e a outra que se intui, uma vez que, ainda que não se sobreponha exactamente, este murete parece respeitar de algum modo um limite mais antigo sugerido pela prospecção geomagnética. A confirmação da existência e da cronologia desta eventual divisória de parcelamento mais antiga passa, porém, pela conclusão da intervenção da sondagem 5.

Por sua vez, uma outra intervenção (sondagem 8) revelou a existência de outro muro constituído por uma fiada de grandes blocos graníticos irregularmente facetados, com uma orientação SO/NE, perpendicular àquele que antes referimos (Fig. 15). Este muro situa-se apenas alguns metros para sul dum limite actual de propriedade materializado no terreno por pequenos marcos bastante espaçados. Também aqui, poderá verificar-se outro caso de isoclinação, sendo provável que este muro seja o elemento morfogenético (IDEM: ibidem) que está na origem do limite de propriedade actual. Ainda que não se tenham encontrado em contextos estratigráficos adequados - materiais que permitam propor uma datação para este muro, o facto de corresponder a um limite claro entre a zona A e a zona $\mathrm{C}$ aponta no sentido deste poder ser contemporâneo da ocupação romana do sítio (Fig. 5 e 15).

A estes dois muros, que parecem delimitar a envolvente mais imediata do núcleo edificado a nordeste e a sudeste, poder-se-ia juntar um outro, em parte talhado no afloramento granítico, que corre a noroeste acompanhando o talude que se encontra nas traseiras do edifício da quinta (Fig. 15).

No que concerne à zona $\mathrm{B}$, esta apresenta densidades de cerâmica por vezes bem superiores àquelas verificadas na zona $\mathrm{A}$, o que poderia levar a interpretá-la como área habitacional (Fig. 5 e 15). A proporção entre tipos de material observado é igualmente bastante próxima. No entanto, a inexistência de anomalias magnéticas nesta área não se coaduna muito com este tipo de ocupação do solo. Assim, as elevadas densidades de material registadas nesta área podem antes explicar-se pela utilização deste espaço como lixeira por parte dos habitantes do estabelecimento. Esta interpretação é compatível com a hipótese anteriormente defendida segundo a qual o muro identificado na sondagem 8, situado imediatamente para norte da zona B, serviria de limite a uma área preferencial de actividade dos habitantes de "Terlamonte I", deli- 
mitando assim uma espécie de grande pátio ou eido murado. Neste caso, a existência de uma lixeira na proximidade da(s) casa(s) da quinta deve relacionar-se com a preocupação dos seus habitantes em manter limpa a área habitacional, bem como as áreas imediatamente envolventes. $\mathrm{O}$ facto de não se ter recolhido material arqueológico no elemento interfacial da sondagem 7 , correspondendo ao topo do paleossolo presumivelmente contemporâneo da ocupação do sítio, ganha assim algum sentido. Ao constituir uma área de actividade preferencial, logo em frente da fachada principal do edifício, todo este espaço seria certamente alvo de limpezas periódicas, sendo os detritos domésticos despejados numa área mais afastada, correspondendo esta - segundo a nossa proposta interpretativa - à zona B.

As densidades medianas de material observadas na zona $\mathrm{C}$, bem como o carácter uniforme desta mancha, sugerem que se trate igualmente de uma área preferencial de actividade dos habitantes do estabelecimento (Fig. 4, 5 e 15). O mapa de drenagem do terreno permite verificar que esta zona se encontra em grande parte na margem esquerda de uma pequena linha de água sazonal. A vizinhança da água, a predominância de declives suaves e a sua proximidade em relação à zona habitacional são compatíveis com o seu aproveitamento agrícola, no quadro de um sistema de cultivo que poderia exigir abundantes recursos aquíferos e um cuidado constante. Assim, esta zona reuniria as condições necessárias para a prática da horticultura, podendo-se também explicar em grande parte a presença do material observado à superfície em função de um processo periódico de adubagem dos solos (ZAPATERO e FERNÁNDEZ: 1993: 93). No entanto, a confirmação desta hipótese implica necessariamente a realização de outros tipos de análise não contemplados, por enquanto, neste primeiro estudo. A presença de alguns alinhamentos de pedras visíveis à superfície, descobertos recentemente logo a NO desta área - no prolongamento daquele que delimita a área edificada para noroeste (Fig. 15) - parecem configurar um pequeno edifício de apoio à actividade agro-pastoril. Parte do material cerâmico registado nesta possível horta poderá assim também resultar da sua deslocação por gravidade a partir dos relevos sobranceiros, onde se observaram estes alinhamentos.

Por sua vez, a zona D, caracterizada pela predominância quase absoluta de densidades de material pouco significativas, reveladas por materiais muito dispersos, adequa-se bem ao conceito de área de actividade limitada (Fig. 5 e 15). Este tipo de área caracteriza-se por ocupa- 
ções esporádicas ou curtas no tempo de um dado espaço (IDEM: ibidem). A exploração dos óxidos de ferro dos filões brechóides de quartzo e a sua mineração in loco, que parecem documentar-se nas sondagens 1 e 2, devem estar na origem da formação desta mancha e poderão ajudar a perceber a representação percentual por tipos de materiais aí registada. Assim, desde logo, esta actividade explicará a elevada percentagem de minério - cerca de 14 vezes superior à das restantes zonas - e de escória - entre 3 a 7 vezes superior - observados à superfície. A cerâmica de mesa está igualmente sobre-representada - entre 3 a 6 vezes superior -, podendo isto relacionar-se com os trabalhos de mineração e com a vigia constante dos fornos durante o processo de redução do minério, na medida em que o(s) operadore(s), ao permanecerem temporariamente nessa área, poderiam aí tomar, por exemplo, algumas refeições.

Os resultados das sondagens de controle efectuadas nesta área (Sond. 1 e 2) sugerem uma correspondência deste tipo de estruturas com as anomalias magnéticas de tipo B, anomalias essas que ocorrem quase exclusivamente nesta zona e que totalizam cerca de três dezenas (Fig. 9 e Tabela 1). Esta quantidade assinalável de prováveis estruturas de combustão parece coadunar-se com o facto de estas - se forem entendidas como fornos metalúrgicos em cova - serem geralmente de pequena dimensão - como forma de alcançar e manter com maior facilidade as temperaturas necessárias para a redução inicial do minério - e se situarem junto aos veios minerais exploráveis, o que na prática se traduziria na sua multiplicação por toda a área explorada (GómEZ RAMOS, 1999). A observação do mapa interpretativo da prospecção geomagnética sugere ainda uma dispersão não aleatória deste tipo de estruturas, uma vez que surgem em pequenos núcleos de dimensões variáveis. Se atendermos à organização espacial destes possíveis fornos podermos equacionar a hipótese de cada núcleo corresponder à exploração de um mesmo filão, sendo este logo abandonado uma vez esgotado o minério nele contido. Trata-se, assim sendo, de uma actividade com uma curta duração no tempo e que implicaria um abandono definitivo do espaço após a conclusão da extracção e redução do minério ${ }^{14}$. Neste sentido, a interpretação desta zona como área de actividade limitada é compatível com este tipo de exploração. A importância, porém, desta actividade

14 Uma vez esgotados os filões de quartzo da zona $\mathrm{D}$, os habitantes terão procurado filões noutras áreas mais distantes da área habitacional; assim, esta estratégia poderá também explicar a presença das anomalias B1 e B2 nos sectores J e L.

Conimbriga, 43 (2004) 99-147 
no quadro da economia do estabelecimento não deve ser muito valorizada, uma vez que a escória é apenas um elemento residual na repartição percentual dos tipos de materiais observados durante a prospecção, constatação essa, aliás, que é corroborada pelos trabalhos de escavação arqueológica efectuados na área edificada do estabelecimento. Como também já foi referido, este tipo de mineração e fundição deve ser entendida como actividade dimensionada à escala familiar e que visaria, fundamentalmente, suprir as necessidades particulares em alguns artefactos em ferro.

Nesta fase, o cenário que traçámos terá que ser necessariamente perspectivado com as devidas reservas, dadas as dúvidas que subsistem - e que só poderão ser esclarecidas com a continuação deste processo de investigação - acerca da exacta cronologia e funcionalidade destas estruturas em negativo documentadas na zona D. Inegável, no entanto, parece-nos ser o carácter antrópico destas "fossas e valas", dada a sua natureza e configuração estratigráfica. Aliás, o carácter antrópico de pelo menos uma destas fossas (sond. 2) e, inclusivamente, a intencionalidade da recolha de uma determinada espécie arbórea encontrada no seu interior sob a forma de carvões, parece ressaltar dos estudos de arqueobotânica efectuados por Paula Queiroz, Win Van Leeuwaarden e José Eduardo Mateus, no âmbito do programa de colaboração estabelecido com o CIPA (QuEIROz et alii, 2003). Com efeito, a análise de um conjunto de material lenhoso carbonizado recolhido no interior da fossa da sondagem 2 permitiu identificar essencialmente amostras de pinheiro bravo (Pinus pinaster) - apenas uma amostra era constituída por madeira de medronheiro (Arbutus unedo) -, parecendo reflectir "a selecção do pinho como principal fonte de combustível (lenha)" (IDEM: 6) destas presumíveis estruturas de combustão ${ }^{15}$.

Ainda que provisoriamente relacionemos estas estruturas com os processos de extracção e de redução inicial de minério - não obstante a ausência no interior das "fossas" de restos minerais dessa actividade

15 Já os resultados da análise polínica dos sedimentos silto-arenosos recolhidos numa coluna de amostras no interior da vala da sond. 7 - análises igualmente efectuadas no âmbito do programa de colaboração estabelecido com o CIPA - não foram, todavia, conclusivos, dada a secura e a natureza textural não argilosa destes sedimentos. Com efeito, "mesmo com o método de hiperconcentração utilizado, os resultados da análise polínica revelaram-se infrutíferos para a obtenção de concentrações polínicas passíveis de serem estudadas": QuEIROZ et alii, 2003: 3.

Conimbriga, 43 (2004) 99-147 
transformadora não deixar de nos inquietar 16 -, os dados cronológicos que obtivemos para elas após a conclusão dos trabalhos de campo - e já numa fase algo adiantada do tratamento posterior dos dados - vieram, por um lado, suscitar ainda mais interrogações acerca da sua funcionalidade e, por outro lado, tornar mais premente a continuidade dos trabalhos (designadamente na área dos estudos geoarqueológicos). Com efeito, uma das questões que desde o início continuava a suscitar dúvidas e necessitava de uma resposta mais esclarecedora e fundamentada relacionava-se com a própria cronologia dessas "fossas e valas", uma vez que não foi possível recolher durante a escavação qualquer material arqueológico associado passível de datação. À partida, dado o seu posicionamento na sequência estratigráfica e perante o facto do local revelar até então apenas vestígios do período romano, colocámos a hipótese destas estruturas serem contemporâneas dessa ocupação. Todavia, os carvões que aí recolhemos (nas "fossas" das sondagens 1, 2 e também na "vala" da sondagem 7) e que enviámos posteriormente para datação radiocarbónica para o Centrum voor Isotopen Onderzoek (Groningen), apontaram todos invariavelmente para uma cronologia pré-histórica (TLM $1-4130 \pm 60$ BP; TLM $2-4350 \pm 60$ BP; TLM $7-4070 \pm 100$ $\mathrm{BP})$. A convergência da datação destas três amostras, recolhidas no enchimento de três estruturas distintas, num momento que se enquadra no Calcolítico Médio ou no Calcolítico Final / inícios da Idade do Bronze17, não deixa de ser perturbadora. A descoberta de um pequeno povoado aberto pré-histórico - inédito - situado a cerca de $600 \mathrm{~m}$ para sul do sítio que estudamos numa ligeira elevação sobranceira ao Zêzere ${ }^{18}$ (Fig. 1) e a identificação de ténues vestígios aparentemente pré-históricos recentemente detectados em escavação no interior da área edificada de

16 A ausência de escórias neste tipo de fornos que não atingiriam temperaturas muito elevadas poderá, todavia, explicar-se pelo facto destas serem novamente recolhidas e trituradas logo após um processo de redução inicial, voltando a ser refundidas como forma de se recuperar a maior quantidade possível de metal; em minerações mais antigas, como seja a do cobre, a ausência de escórias poderá ser uma resultante quer da elevada pureza do mineral utilizado, quer da não adicionação de fundentes (GómEZ RAMOS, 1999).

17 Se considerarmos o resultado da análise da amostra TLM 2.

18 Numa área relativamente reduzida - c. $1000 \mathrm{~m} 2$ - encontrámos escassos fragmentos de cerâmicas manuais, um "pingo de bronze" (?) e alguns dormentes de mós "de sela” (coord. UTM: 633800.4461000, CMP. 1/25.000 - 235). 
"Terlamonte I"19 (Fig. 15), poderão em certa medida aduzir mais algum crédito a esta datação. Contudo, é difícil aceitar uma cronologia tão antiga para as estruturas de combustão detectadas nas sondagens 1 e 2, uma vez que todos os dados disponíveis até ao momento apontam para a sua interpretação como estruturas relacionadas com a redução inicial do ferro. A realização de novas datações radiocarbónicas de amostras provenientes destas estruturas está prevista no quadro da continuação da investigação deste sítio. Este pequeno "transtorno" inesperado no percurso de investigação desenvolvida não deixa porém de ser revelador da dificuldade que o arqueólogo encontra - e do risco que corre - quando tenta cristalizar um determinado momento da formação de uma paisagem, dado que esta por natureza é um sistema dinâmico e resultante das relações dialéticas que se estabelecem entre os homens e o meio físico (LOPES, 2003: 302).

\section{Considerações finais}

Em território nacional, a classificação de sítios romanos com base nos materiais de superfície tem a sua origem no estudo pioneiro que a equipa luso-francesa levou a cabo na região da Vidigueira entre 1981 e 1982, no quadro da intervenção arqueológica de São Cucufate (ALARCÃO et alii, 1990). O despertar, passados vinte anos, para este tipo de abordagem, deve-se em grande parte ao artigo publicado por Alarcão em 1998 sobre a paisagem rural romana e alto-medieval em Portugal (ALARCÃo, 1998), onde este autor propõe uma classificação de sítios rurais romanos em função da área de dispersão, do tipo de material recolhido e da proximidade espacial entre sítios, critérios esses aplicáveis a todo o território nacional. Esta metodologia tinha já sido durante a década de 90 ensaiada em algumas regiões (ver, a título de exemplo, LOPES et alii, 1997, continuada depois em LOPES, 2003), sendo, mais recentemente, aplicada a algumas zonas da Beira Interior, como sejam a bacia hidrográfica do rio Côa (OsÓRIO, 2000 e PERESTRELO, 2003) ou o curso médio da ribeira da Meimoa (CARVAlHo et alii, 2002). Um denominador comum a todos estes trabalhos parece residir no advogar duma

19 Trata-se de uma pequena fossa escavada no substrato contendo alguns fragmentos de cerâmica exclusivamente manual (UE 10 de E.7'-a). 
adaptação dos parâmetros desta classificação em função da região estudada e da necessidade de se entenderem os sítios no quadro da exploração dos recursos.

O ponto mais débil deste tipo de abordagem, porém, parece residir no pressuposto de que existe uma relação - ainda não demonstrada - entre área de dispersão de vestígios e tipo de estação (ALARCÃo, 1998: 95). Esta debilidade exige que os planos de prospecções contemplem processos pontuais de escavação. A via seguida pela equipa luso-francesa, que efectuou sondagens de diagnóstico em alguns dos sítios avaliados (cerca de $23 \%$ do conjunto), de modo a confirmar a validade das suas classificações, não foi infelizmente seguida nos trabalhos posteriores. No entanto, a validação da classificação através da escavação arqueológica será imprescindível para que este tipo de análise adquira o estatuto de método que parece ser desejado pelos seus seguidores.

Deve-se igualmente salientar que esta metodologia de classificação se baseia num outro pressuposto muitas vezes implícito: de que a área ocupada pela mancha de dispersão de materiais corresponde grosso modo à área (coberta ou telhada) ocupada pelos edifícios do estabelecimento analisado. No entanto, como se referiu anteriormente, parte das manchas de dispersão de material podem relacionar-se igualmente com áreas de actividade preferencial ou mesmo com áreas de actividade limitada. Poderá talvez existir uma relação por demonstrar entre o espaço ocupado pela área habitacional de um determinado assentamento e a(s) área(s) de actividade preferencial que lhe é (são) contígua(s). Porém, dificilmente se pode admitir o mesmo em relação á áreas de actividade limitada relacionadas com esse mesmo assentamento. De facto, ainda que possa existir uma relação com a dimensão e natureza do núcleo edificado, o tamanho destas áreas dependerá certamente mais do tipo de actividade exercida e da duração da ocupação do sítio relacionado com essa exploração. Seja como for, no caso em estudo, a zona D, interpretada como área de actividade limitada, não representa menos que $73 \%$ do espaço ocupado pelas zonas A, B, C e D. As zonas A, B e C, por sua vez, representam individualmente apenas cerca de $9 \%$ da área de estudo. Se interpretássemos todas estas áreas como áreas habitacionais (zonas A, B, C, D), a área potencialmente construída passaria de 1.650 $\mathrm{m} 2$ (zona A + áreas limítrofes das sondagens 3 e 6) para $18.275 \mathrm{~m} 2$, ou seja, seria 10 vezes maior! Assim, o papel que este tipo de abordagem pode ter na racionalização da classificação de sítios através da avaliação ponderada da sua(s) mancha(s) de dispersão - distinguindo-se nestas as 
áreas circundantes em que os materiais aparecem mas de uma forma comprovadamente residual - parece ser evidente. Ao mesmo tempo, a identificação através desta metodologia das áreas "marginais" dos sítios - onde os materiais surgem de forma muito esporádica - poderá também orientar ou deslocar a atenção da investigação para os espaços abertos produtivos, para os espaços onde muitas das actividades humanas se desenrolavam periodicamente, isto é, para a chamada arqueologia off-site ${ }^{20}$.

$\mathrm{Na}$ ausência de uma prospecção de superfície por quadriculagem, parece-nos pelo menos desejável que se estabeleça um valor crítico de densidade de materiais a partir do qual a área ocupada pela mancha de dispersão poderá corresponder grosso modo à área edificada do sítio em análise. De facto, sem estabelecer este mínimo, "Terlamonte I" poderia ser considerado como uma villa, uma vez que a mancha de dispersão é bem superior aos $5.000 \mathrm{~m}^{2}$, ultrapassando mesmo os $10.000 \mathrm{~m}^{2}$ referidos anteriormente como fasquia mínima para autorizar a classificação de um sítio como tal. Todavia, este limite pode variar muito de sítio para sítio dependendo em grande parte quer da visibilidade que oferece o terreno no momento da prospecção, quer do peso do factor topográfico. Ainda que as tradicionais prospecções de superfície não explicitem a metodologia utilizada para determinar a área ocupada pelas manchas de dispersão, supõe-se que as dimensões atribuídas a essas áreas resultem apenas de uma estimação empírica e não de uma medição, como foi aqui o caso. Como o limite da densidade de material mínimo considerado não é especificado, será natural que este factor varie de acordo com o observador e, assim sendo, a área proposta para um mesmo sítio poderá variar significativamente em função de quem a percorre e a avalia. Este problema - decorrente da não uniformização dos critérios de classificação - ganha relevância quando se pretende comparar os resultados de classificações obtidas por dois investigadores em áreas distintas, limitando-se assim seriamente a legitimidade de comparações supra-regionais.

Nestas classificações, não se pode ainda deixar de ter em atenção que, na maior parte dos casos, a zona edificada será inferior à área ocupada pela mancha de dispersão. Neste sentido, a análise da micro-topografia dos assentamentos estudados poderá permitir uma leitura crítica

20 A este nível, as prospecções geomagnéticas poderão igualmente desempenhar um importante papel na definição das estratégias de intervenção no terreno.

Conimbriga, 43 (2004) 99-147 
da medição da área ocupada por uma mancha de dispersão de materiais, na medida em que a topografia constitui um factor relevante no processo de deslocação de materiais arqueológicos (GERRARD, 1995: 138-140).

A discriminação dos tipos de materiais representados num sítio contribui igualmente para a sua classificação. Neste sentido, seria interessante renovar em pequenos sítios, casais, villae e aglomerados secundários a experiência aqui apresentada, como forma de verificar se existe uma variação percentual significativa - em termos quantitativos e qualitativos - entre diferentes tipos de sítio. Esta abordagem seria decerto menos redutora que a simples constatação da sua ausência ou da sua presença e poderia talvez permitir a determinação de uma assinatura multi-espectral para cada tipo de sítio, aplicando-se para isso um método semelhante àquele generalizado na interpretação de imagens satélites. Neste tipo de análise, a interpretação dos píxeis (sítios) seria efectuada com base na análise conjunta de diversos canais de informação (quantidade percentual de material identificado por tipos) (WILMET, 1993: 80).

Regressando ao exemplo de São Cucufate, verificou-se aí que mais de um terço dos sítios escavados, que apresentavam cerâmicas romanas à superfície, eram na verdade sítios medievais e modernos com reutilização de materiais de construção romanos, não se constatando a existência de nenhum pequeno sítio romano (AlARCÃo et alii, 1990: 177). Com base numa análise mais fina decorrente de um plano de prospecção de superfície em quadrícula, a quantificação da relação percentual entre materiais romanos e materiais medievais / modernos (em particular a relação percentual telha de meia cana / telha romana) teria certamente permitido negar uma cronologia romana a alguns destes sítios sem se proceder a uma intervenção arqueológica (SILVA, 2001). Assim, por um processo similar àquele definido por Harris (1989) para distinguir material "indígena" / original do material residual e infiltrado contidos numa mesma unidade estratigráfica, a relação percentual entre materiais arqueológicos de diferentes cronologias, observados durante este tipo de prospecção, poderia revelar o reaproveitamento de materiais de construção mais antigos, entendidos como materiais residuais. Esta análise é particularmente pertinente nos pequenos sítios, onde este fenómeno se verifica frequentemente.

Em suma, perante o exposto, parece-nos que a aplicação da prospecção de superfície por quadriculagem a um conjunto de sítios roma- 
nos ao nível de uma meso-área, seguindo rigorosamente um mesmo protocolo e racionalmente conjugada com um programa de sondagens de controle, apoiadas num plano de prospecções geomagnéticas, permitiria certamente incrementar fortemente o conhecimento do povoamento rural de uma dada zona. Esta estratégia - necessariamente a levar a cabo por amostragem e com base na selecção de sítios criteriosamente seleccionados em função das suas características e representatividade no conjunto - poderia permitir detectar regularidades e estabelecer um padrão para o registo de superfície dos diferentes tipos de sítios, dotando assim de bases mais sólidas as classificações efectuadas mediante uma observação empírica - e logo mais expedita - das manchas de materiais dispersas à superfície.

Uma vez que a prospecção geomagnética - e de um modo mais geral a prospecção geofísica - sempre teve pouca divulgação entre nós, é talvez o momento e o lugar apropriado para enunciar de forma concisa o interesse, os limites e as perspectivas que oferece a integração desta ferramenta numa estratégia de investigação arqueológica.

Como qualquer tipo de método, convém desde logo esclarecer que a geomagnética não pode ser considerada como uma panaceia - que dispensa a escavação - pelo facto de ser capaz de produzir uma "radiografia" do sítio onde é captada uma planta dos elementos arquitectónicos que a constituem. Esta situação ocorre em ocasiões muito raras (a título de exemplo HidAlgo et alii, 1999), devido à conjugação de uma série de factores favoráveis (estruturas monumentais, meio envolvente muito contrastante e fraca potência estratigráfica). Os prospectores são um pouco responsáveis pela existência deste mito entre os arqueólogos, uma vez que raramente se publicam prospecções geofísicas que dão maus resultados ou que, pelo menos, não caracterizam de forma explícita as estruturas arqueológicas estudadas (MU`IÈ, 2001:128).

Por outro lado, é importante lembrar que as estruturas arqueológicas não são as únicas a provocar anomalias magnéticas. Na hora de interpretar o mapa geofísico, é importante ter em mente que grande parte das anomalias terá causas pedológicas, geológicas ou resultará da actividade antrópica contemporânea (caminhos, lavra dos terrenos, plantação de árvores, lixeiras recentes, postes de alta tensão, etc). É preciso entender o solo como um palimpsesto que fossiliza alguns episódios da sua longa vida e apaga outros, sem fixar obrigatoriamente a sua ordem ou a sua importância relativa. Quanto maior for a resolução do instrumento de medição e quanto mais fina for a malha de estudo, maior será 
a complexidade do mapa geomagnético e mais árdua será a tarefa de isolar anomalias de carácter arqueólogico, das restantes. A sobreposição de outras informações para além das arqueológicas pode ser no entanto um trunfo importante para a contextualização destas estruturas no seu quadro ambiental.

Apesar destas limitações, a prospecção geomagnética tem a vantagem de permitir acumular dados rapidamente e/ou com poucos recursos financeiros sobre grandes panos de terreno, permitindo integrar os sítios no seu contexto local e identificar estruturas relacionadas ou actividades desenvolvidas situadas, por vezes, bem longe da área construída e das manchas de densidades significativas de materiais de superfície. As estruturas detectadas, tais como fossas, poderiam passar facilmente desapercebidas numa escavação menos cuidada ou menos atenta ou poderiam não ser valorizadas em prospecção, por não estarem representadas à superfície.

É assim difícil de perceber o papel insignificante que continua a desempenhar a prospecção geofísica no quadro da arqueologia de salvamento nacional. De facto, se a não observação deste tipo de estruturas num sítio arqueológico, que não se encontra ameaçado, reduz apenas os resultados da intervenção, a mesma situação numa intervenção de salvamento significa a perda definitiva desta informação. Ora isto acontece todos os dias e com uma frequência cada vez mais elevada.

Para finalizar, parece-nos que este tipo de estratégia concertada de investigação levada a cabo na área onde se instalou um dado habitat, não deixará de se revelar igualmente importante ao nível dos estudos sobre o povoamento antigo de âmbito regional, uma vez que as estruturas sociais e económicas que se encontram subjacentes aos padrões de ocupação e organização territorial serão provavelmente melhor perspectivadas se enveredarmos por um processo em que uma das escalas de análise adoptada seja precisamente aquela que incida de forma mais detalhada sobre algumas das unidades domésticas consideradas mais representativas. Com este procedimento, procurar-se-á - através da identificação funcional dos diversos espaços interiores e exteriores ao núcleo edificado e em função da análise das relações que estabelecem com os recursos naturais - aceder, desde logo, ao tipo de organização familiar que materializou essas unidades rurais que surgem de forma mais recorrente no registo arqueológico e que estruturariam o espaço rural. Esta etapa poderá depois ser decisiva para a análise dos laços sociais e das relações de produção que se estabeleceram numa dada região, liga- 
ções essas que constituem uma componente fundamental - e que estão na génese - da paisagem cultural que se vai construindo.

\section{Agradecimentos}

Para a elaboração deste trabalho foi imprescindível o apoio concedido por uma série de instituições: Instituto Português de Arqueologia, Fundação da Ciência e da Tecnologia, Escola Profissional Agrícola Quinta da Lageosa (Belmonte), Centro de Estudos Arqueológicos das Universidade de Coimbra e Porto, Instituto de Arqueologia da Universidade de Coimbra e Post Quem Ld. ‥ Agradecemos ainda a colaboração de Paula Queiroz, Win Van Leeuwaarden e José Eduardo Mateus (Centro de Invest. em Paleoecologia Humana e Arqueociências), Fernando Rocha Almeida e Paulo Morgado (Dep. Geociências da UA), Lídia Catarino e Fernando Pedro Figueiredo (Dep. Ciências da Terra da UC), Ricarda Moura e Paulo Ricardo (Geosonda Ld. ${ }^{\text {) }}$, Ana Carreira e Otília Ribeiro (Fuso 29, Trab. Top. Ld.a ), J. van der Plicht (Centrum voor Isotopen Onderzoek) e José Luís Madeira (Instituto de Arqueologia da FLUC), assim como também estamos gratos aos alunos da licenciatura em História - variante de Arqueologia da FLUC que participaram, com reconhecido empenho, nos trabalhos de campo: Ana G. Rigueiro, Andreia V. Lourenço, António C. Carvalho, Carla A. Ribeiro, Catarina F. Quinteira, Fernando P. Santos, José S. Nóbrega, Ricardo C. Silva, Ricardo S. Teixeira, Sara O. Almeida, Sofia G. Tereso e Vera C. Pereira. Gostaríamos ainda de sublinhar - agradecendo vivamente - a autorização continuada que o Dr. Carlos Morão de Paiva nos concedeu para levar a cabo estes trabalhos na sua propriedade.

\section{BIBLIOGRAFIA}

AlarCão, J. (1988), O domínio romano em Portugal, Fórum da História, Publ. EuropaAmérica.

AlarCão, J. (1998), “A paisagem rural romana e alto-medieval em Portugal”, Conimbriga, XXXVII, Coimbra, p. 89-119.

Alarcão, J., Étienne, R. e MaYet, F. (1990), Les villas romaines de São Cucufate (Portugal), E. de Boccard, Paris, p. 149-183. 
Almeida, F., Silva, A. M., Alarcão, J. e Carvalho, P. C. (no prelo), "Magnetic interpretation of gradiente field in archeologic prospection", 8th Meeting of Environmental and Engeneering Geophysics (EEGS-ES, 8-12.09.2002, Aveiro). Bernardes, J. P., Gomes, L. C. e CARVAlho, P. S. (1999), "O assentamento romano da Quinta da Fórnea (Belmonte, Castelo Branco). Uma intervenção arqueológica de emergência", in Actas do $1 .{ }^{\circ}$ Encontro de Estradas e Arqueologia, JAE, Lisboa, p. 81-94.

Bichet, V., CAmpy, M. e Petit, C. (1997), «Mise en évidence de l'impact antrhropique sur la sédimentation associée aux sites archéologiques : apports, limites et perspectives», Les formes du paysage, tome 3 - l'analyse des systèmes spatiaux, Éditions Errance, Paris, p. 25-34.

BINTLIFF, J. (2000), «The concepts of 'site' and 'offsite' archaeology in surface artefact survey», Non-destructive techniques applied to landscape archaeology , Ed. M. Pasquinucci and F. Trément, Oxbow Books.

BUtzer, K. W. (1989), Arqueología, una ecología del hombre: método y teoría para un enfoque contextual, Ed. Bellaterra, Barcelona.

Carvalho, P. C. (2003), "O templo romano de Nossa Senhora das Cabeças (Orjais, Covilhã) e a sua integração num território rural”, Conimbriga, XLII, 2003, p. $153-182$.

Carvalho, P. C., Ribeiro, C., Silva, R. e Almeida, S. (2002), "Povoamento rural romano ao longo da Ribeira da Meimoa - Fundão (1. ․ㅡ campanha de prospecção intensiva)", Conimbriga, XLI, p. 127-152.

Chouquer, G. (1997), «La place de l'analyse des systèmes spatiaux dans l'étude des paysages du passé», Les formes du paysage, tome 3 - l'analyse des systèmes spatiaux, Éditions Errance, Paris, p. 14-24.

Clark, A. (2000), Seeing Beneath the Soil - prospecting methods in archaeology, Routledge, London.

DABAS, M. (1998), «La prospection géophysique», La prospection, Collection «Archéologiques», Editions Errance, Paris, p. 161-206.

DAVID, A. (1995), Geophysical survey in archaeological field evaluation, Research \& Professional Services Guidelines - n. ${ }^{\circ}$ 1, Ancient Monuments Laboratory, English Heritage Society.

Domergue, C. (1990), Les mines de la Péninsule Ibérique dans l'antiquité romaine, Collection de l'École Francaise de Rome - 127, Rome.

Espiago, J. e BAENA, J. (1997), "Los sistemas de información geográfica como tecnología informática aplicada a la arqueología y a la gestión del patrimonio", Los S.I.G. y el análisis espacial en Arqueología, UAM Ediciones, Madrid, p. 7$-65$.

ESRI (1996), ArcView GIS - The Geographic Information System for Everyone TM, ESRI Inc., San Francisco.

Frade, M. H. (1996), "La torre de 'Centum Cellas' (Lusitanie) et sa région: quelques renseignements sur l'organization de l'espace”, L'Africa Romana, Ed. Democratica Sarda, p. 885-890.

GERRARD, C. (1995), "Prospección arqueológica y cerâmica medieval / post-medieval: 
problemas e modelos", Actas das 2 $2^{a}$ Jornadas de Cerâmica Medieval e Pós-Medieval (Tondela, 22-25.03.1995), p. 137-143.

Gómez Ramos, P. (1999), Obtención de metales en la Prehistoria de la Peninsula Ibérica, BAR International Series.

HARRIs, E. C. (1989), Principles of archaeological stratigraphy, Academic Press Limited, London.

Hidalgo, J. M. R.; Keay, S. J.; Jordan, D., Creighton, J. (1999), "La Itálica de Adriano - Resultados de las prospecciones arqueológicas de 1991 y 1993", $A r$ chivo Español de Arqueología, vol. 72 - n. ${ }^{\circ}$ 179-180, CSIC, Madrid, pp. 73-97.

Lemos, F. S. e ReI, L. (2000), "Mineração antiga na Serra da Malcata (Beira Interior)", Beira Interior: História e Património, Actas das I Jornadas de Património da Beira Interior (1-3.10.1998), Guarda, p. 185-198.

LoPes, C. (2003), A Cidade Romana de Beja: percursos de debates acerca da "civitas" de Pax Iulia, Conimbriga/Anexos 3, Instituto de Arqueologia, FLUC, Coimbra.

Lopes, C., Carvalho, P. C., Gomes, S. M. (1997), Arqueologia do Concelho de Serpa, Câmara Municipal de Serpa, Câmara Municipal de Serpa.

Matos, J. L. (2001), Fundamentos de Informação Geográfica, Colecção Geomática, Lidel, Lisboa.

MurteiRA, B. F. (1993), Análise exploratória de dados - Estatística descritiva, Mc Graw Hill, Lisboa.

MǓİ̀, B. (2001), "An evaluation of the potential of geophysical prospections in dificult environments - the silent presence of GIS", in On the good use of geographic information systems in archaeological landscape studies, coord de SLAP`AK, B., COST Action G2 - Ancient landscape and rural structures, Luxembourg, p. 127-144. OsóRIo, M. (2000), O povoamento romano do Alto Côa, II vols., Coimbra (dissertação de Mestrado em Arqueologia, policopiada, apresentada à Faculdade de Letras de Coimbra).

Perestrelo, M. S. (2003), A romanização na bacia do rio Côa, Ed. Parque Arqueológico do Vale do Côa.

Perestrelo, M. S. e Ferreira, M. C. (2000): "Povoamento romano na bacia da ribeira de Massueime (Guarda) - Alguns apontamentos", Beira Interior: História e Património, Actas das I Jornadas de Património da Beira Interior (1-3.10.1998), Guarda, p.97-120.

Queiroz, P. F., Van LeeuwaArden, W. e Mateus, J. E. (2003): Estudos de Arqueobotânica na quinta romana de Terlamonte, Covilhã, Trabalhos do CIPA - n. ${ }^{\circ} 43$, IPA, Lisboa.

Ribeiro, Orlando (1949), "A Cova da Beira. Controvérsia de Geomorfologia", Сomunicações dos Serviços Geológicos de Portugal, tomo XXX, Lisboa, p. 5-23.

Roskams, S. (2001): Excavation, Cambridge Manuals in Archaeology, Cambridge University Press.

Silva, A. J. M. (2001), Intervenção arqueológica preventiva no Cotifo de Baixo 3 (Odiáxere, Lagos), relatório n. ${ }^{\circ} 16$, Post Quem - Análise e Consultadoria Arqueológica Ld.., Coimbra, doc. policopiado. 
SILVA, A. J. M. (2002), O sítio romano de Terlamonte: contributo da prospecção de superfície intensiva, da prospecção geomagnética e do SIG nos estudos intra sítio, dissertação de Mestrado em Arqueologia, especialização em Arqueologia Romana apresentada na F.L.U.C., documento policopiado.

Silva, A. J. M. e Silva, R. C. (no prelo), "Resultados da intervenção no sítio arqueológico de Barradas (Odiáxere, Lagos)", Revista Portuguesa de Arqueologia, IPA, Lisboa.

Silva, A. J. M. e Carvalho, P. C. (no prelo), "Intensive survey, geomagnetic, excavation and GIS for the intra-site study of the Roman site of 'Terlamonte I' (Teixoso, Covilhã, Portugal)", 8th Meeting of Environmental and Engeneering Geophysics (EEGS-ES, 8-12.09.2002, Aveiro).

SIM, D. (1998), Beyond the Bloom. Bloom refining and iron artifact production in the Roman world, BAR International Series 725.

TeIXEIRA, C. et alii (1974), Carta Geológica de Portugal (esc. 1/50 000), Notícia Explicativa da Folha 20-B, Serviços Geológicos de Portugal, Lisboa, 1974.

Wilmet, J. (1993), Cours de télédetection II Partie - Méthodes numériques, Laboratoire de Télédetection et d'Analyse Régionale, UCL, Louvain-la-Neuve.

Zapatero, G. R. e FernándeZ, V. M. (1993), "Prospección de superficie, técnicas de muestreo y recogida de información”, Actas de inventarios y cartas arqueologicas, Junta de Castilla y Leon, Soria, p. 87-98. 


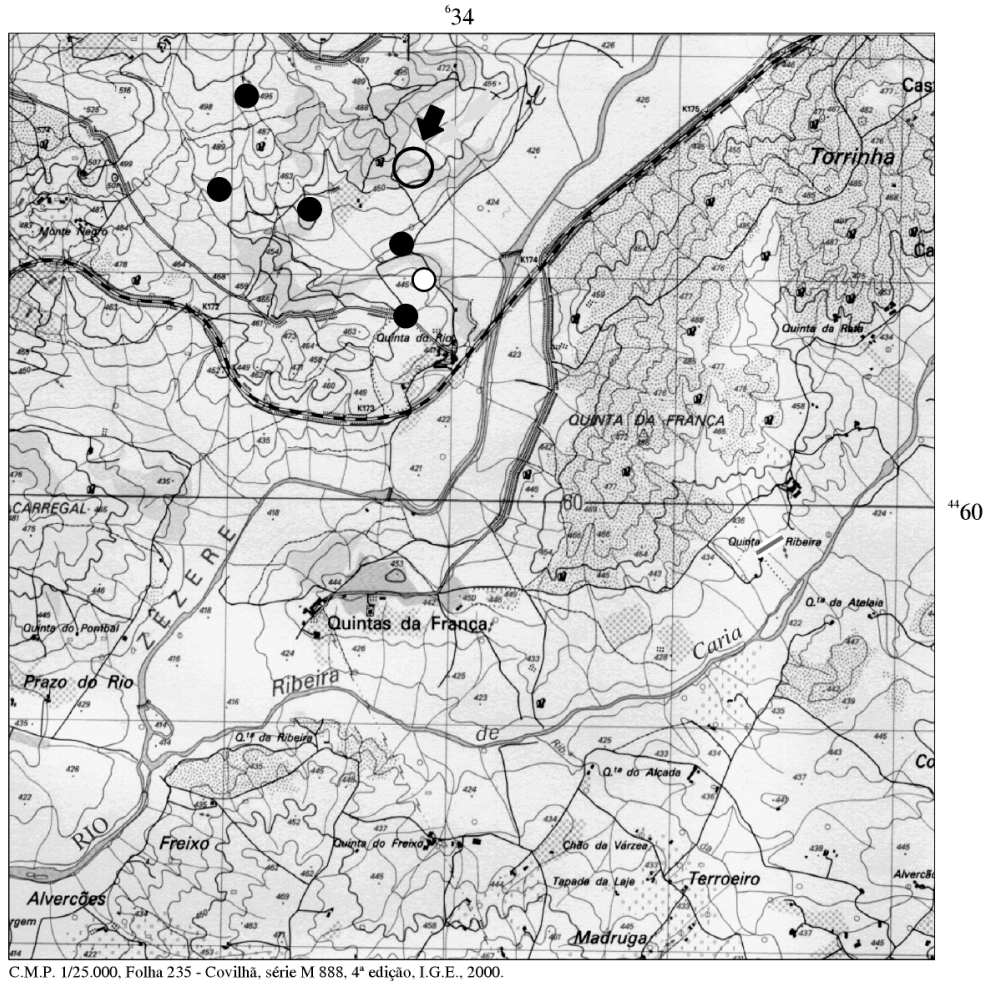

$\bigcirc$ Terlamonte I - quinta

Pequenos sítios dependentes de TLM. 1

Povoado inédito pré-histórico

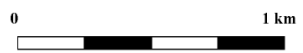

FIg. 1 - Enquadramento de Terlamonte I na Carta Militar de Portugal. 


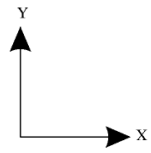

Projecção Hayford Gauss, Elipsóide Internacional 1909 Datum 73 (HG73)

$\mathbb{E}$
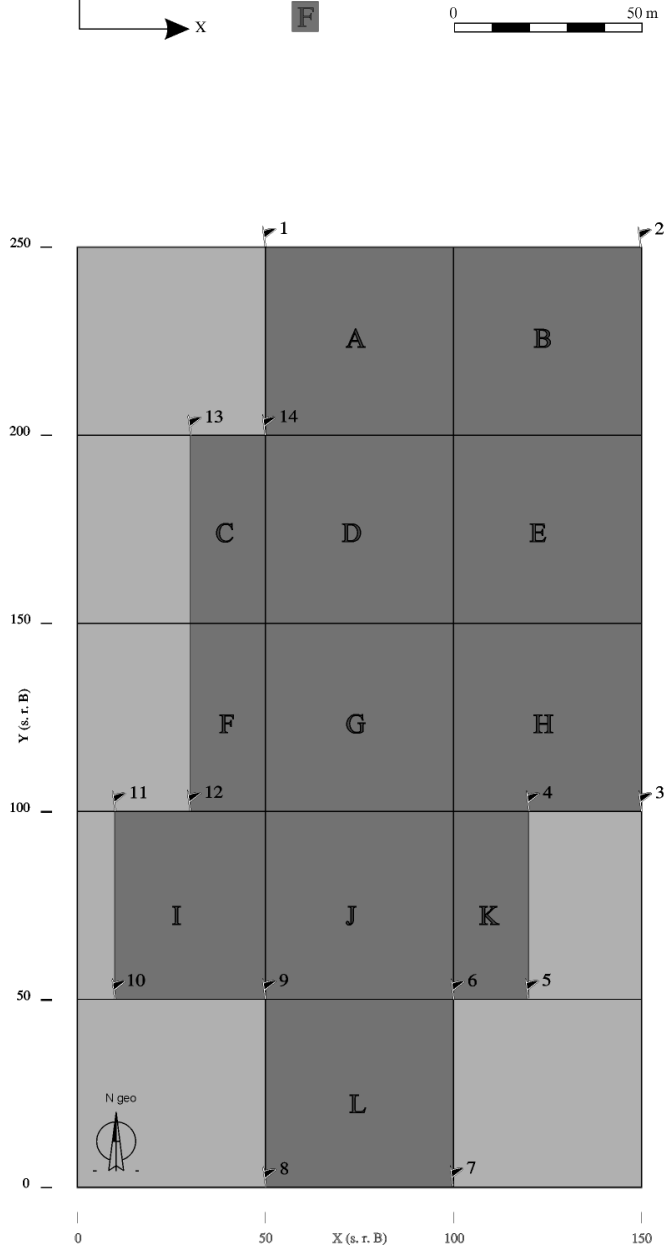

$>1$

$\mathrm{x}=60326.874$ $y=69583.461$

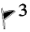
$\mathrm{x}=60426.926$ $z=453.691$

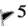

$\mathrm{x}=60396.406$ $\mathrm{y}=69382.557$ $z=451.665$

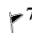

$\mathrm{x}=60376.137$ $=44536$

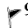

$\mathrm{x}=60326.35$ $y=69382.922$

$z=454.86$

$-11$

$\mathrm{x}=60286.49$ $\mathrm{y}=69433.197$ $z=461.181$

$-13$

$\mathrm{x}=60306.754$ $y=69533.276$ $z=469.436$

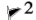

$\mathrm{x}=60427.12$ $y=69583.46$

$-4$

$\mathrm{x}=60396.653$ $\mathrm{y}=69432,800$

$-6$

$x=60376.373$ $\mathrm{y}=69382.71$ $\mathrm{z}=452.788$

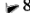

$x=60325.656$ $y=69332.81$
$z=449073$

$-10$

$\mathrm{x}=60286.242$ $\mathrm{y}=69383.083$ $\mathrm{z}=457.286$

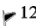

$\mathrm{x}=60306.488$ $\mathrm{y}=69433,069$ $z=459.791$

$-14$

$\mathrm{x}=60326.908$ $\mathrm{y}=69533.358$ $z=466.759$

FIG. 2 - Planta esquemática da área de estudo da intervenção em Terlamonte I. 


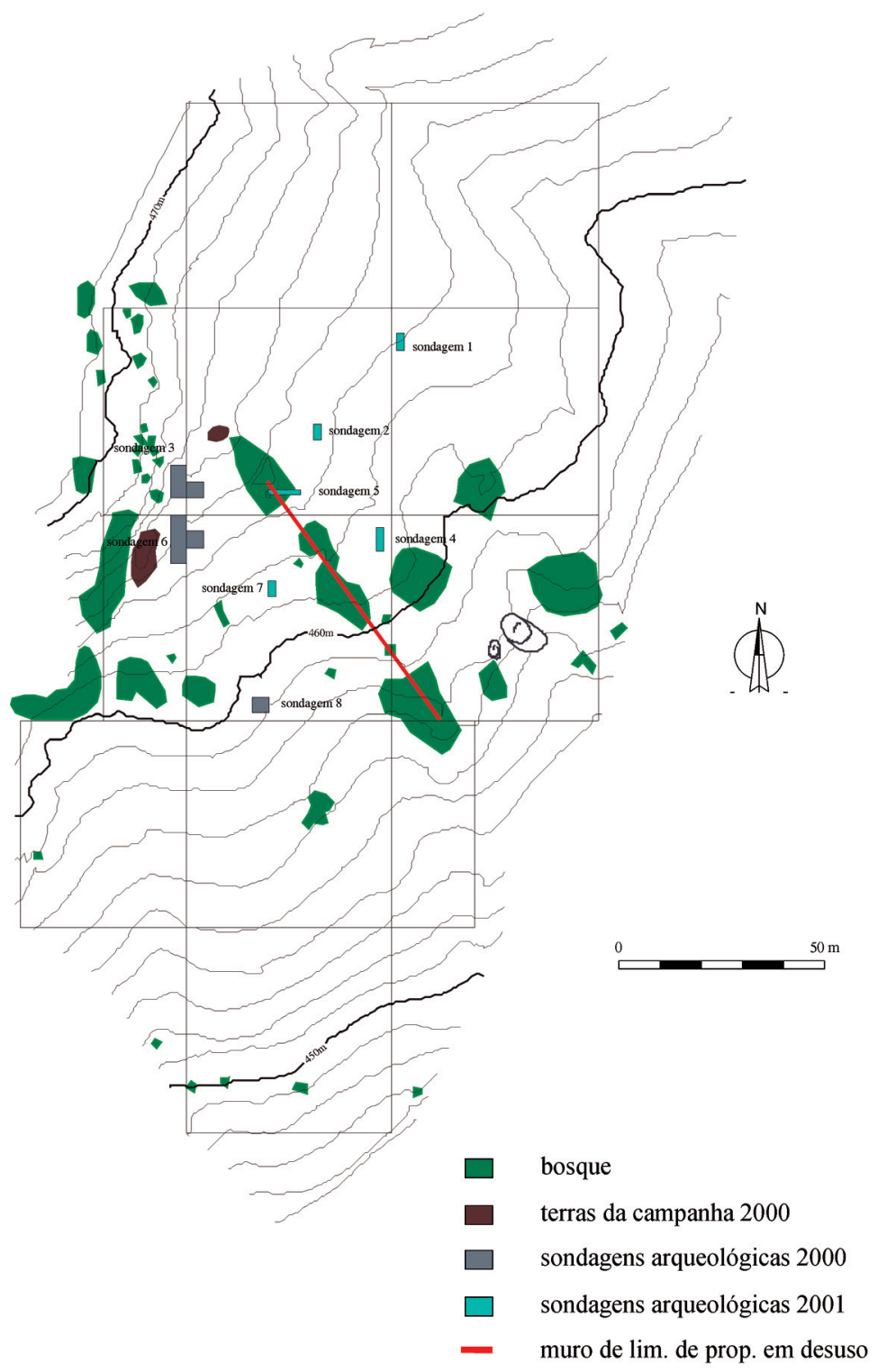

FIG. 3 - Localização das sondagens arqueológicas efectuadas em Terlamonte I, até Setembro de 2001. 

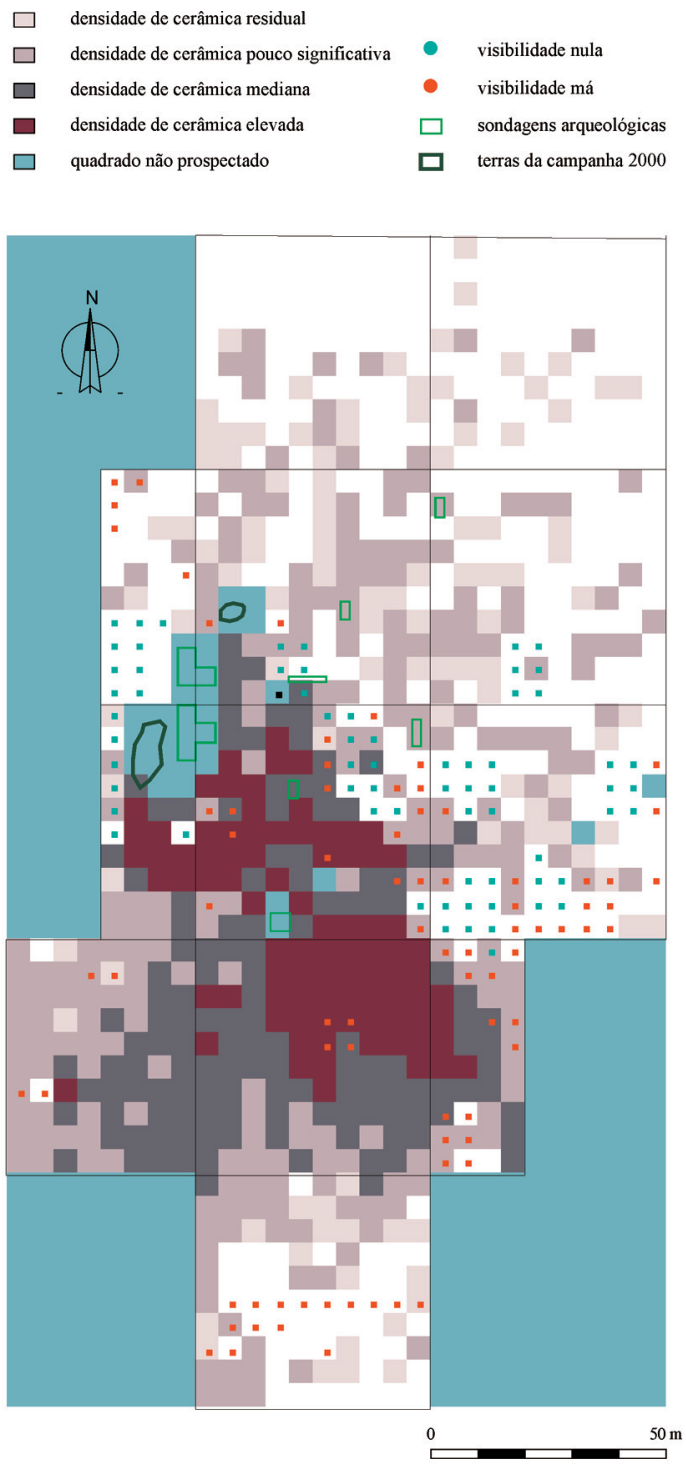

FIG. 4 - Mapa de densidades de materiais da prospecção de superfície em quadrícula realizada em Terlamonte I. 


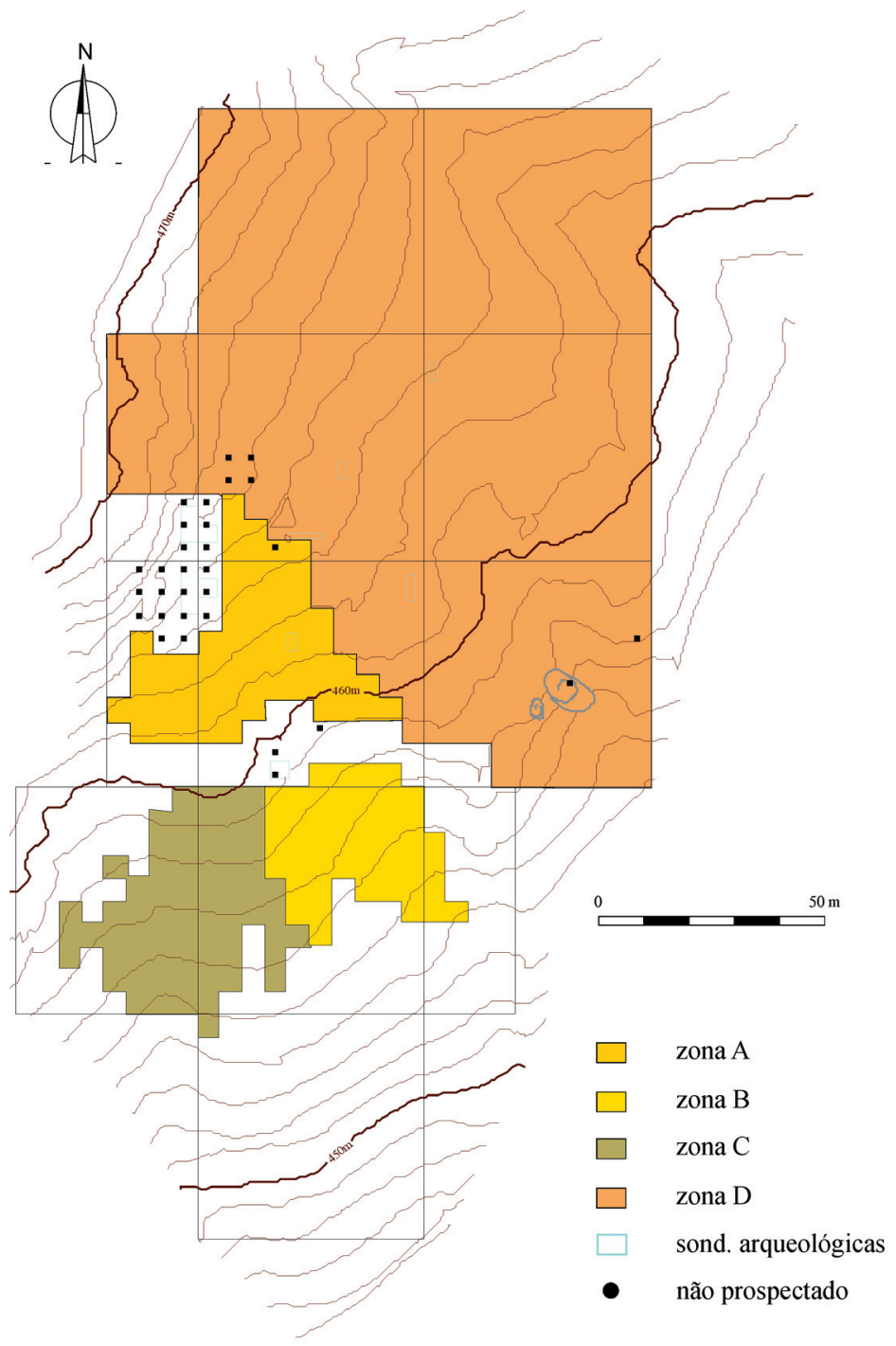

FIG. 5 - Zonas de densidades de materiais cerâmicos da prospecção de superfície em quadrícula realizada em Terlamonte I. 


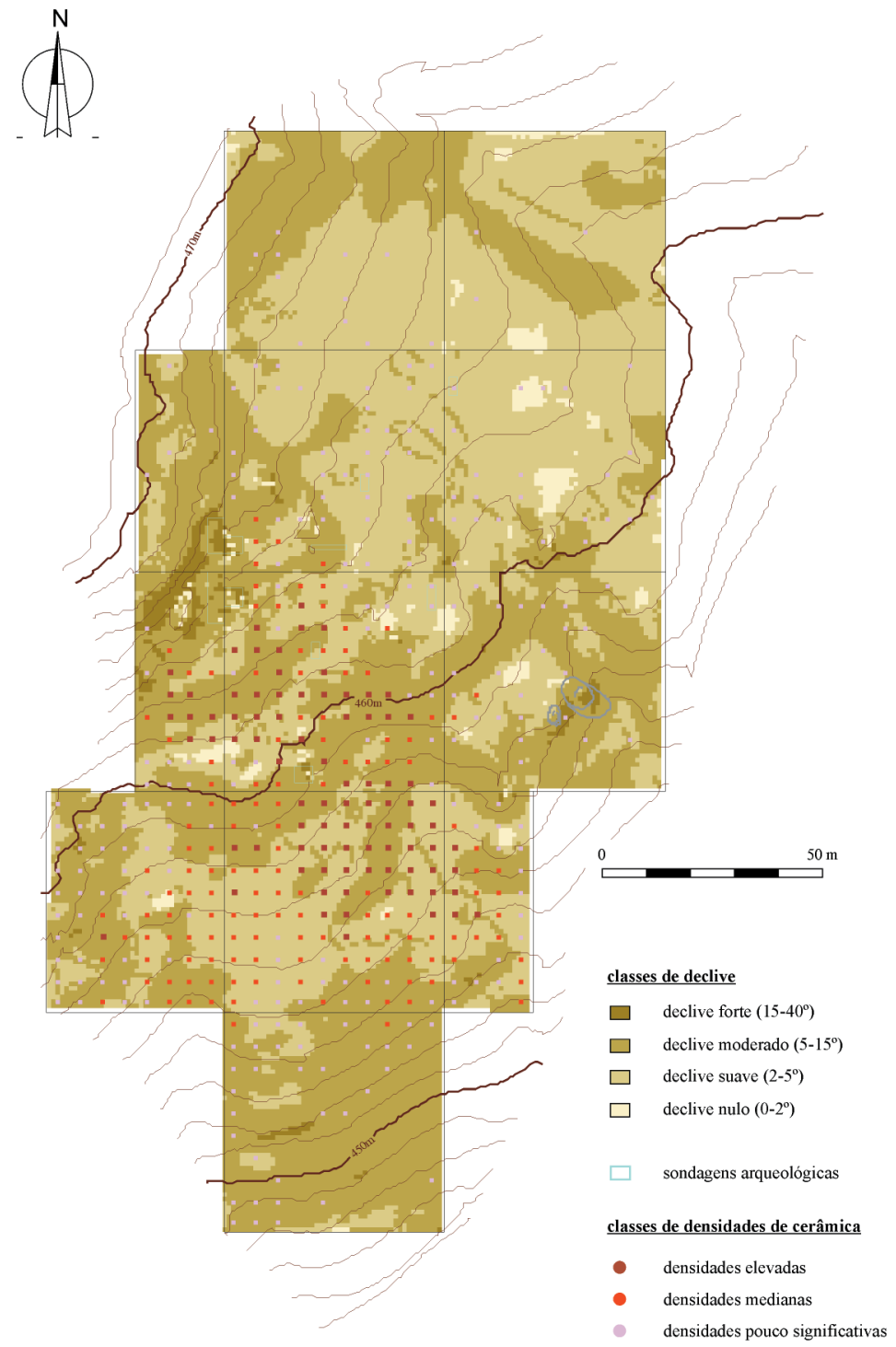

FIG. 6 - Densidades de material e declive na prospecção de superfície em quadrícula realizada em Terlamonte I. 


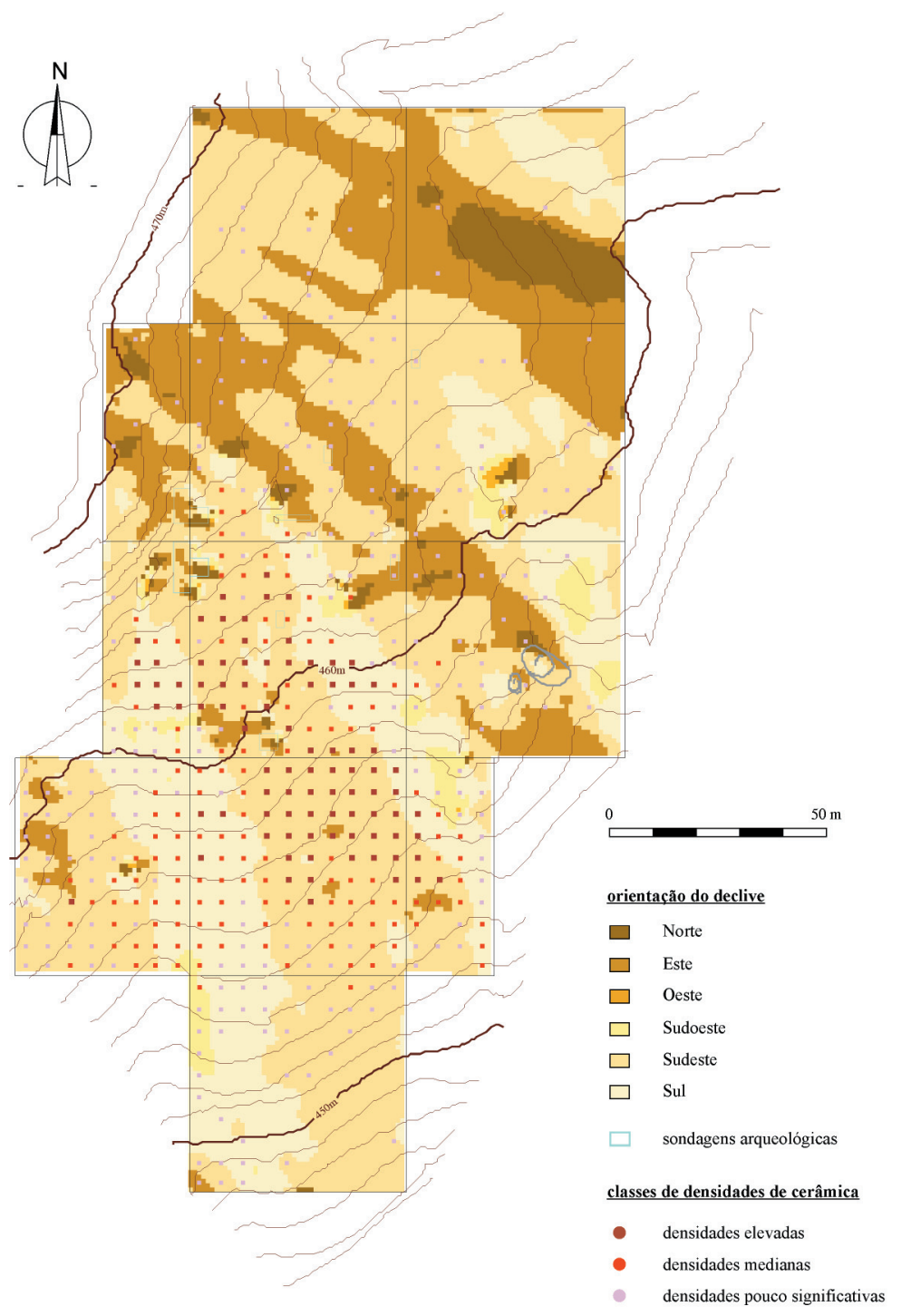

FIG. 7 - Densidades de material cerâmico e orientação do declive na prospecção de superfície em quadrícula realizada em Terlamonte I. 
0
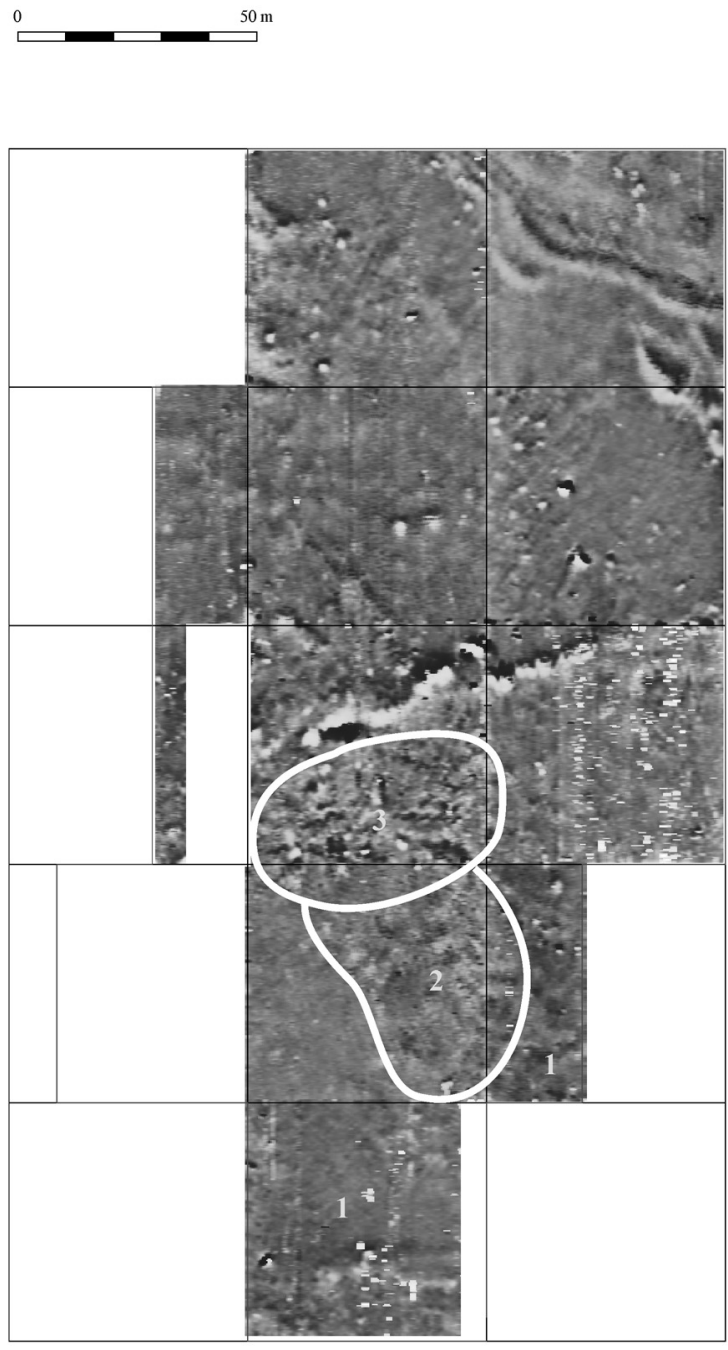

N

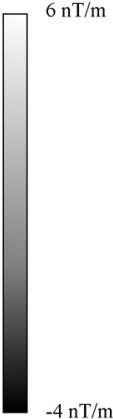

FIG. 8 - Zonas de gradiente vertical na prospecção geomagnética de Terlamonte I. 

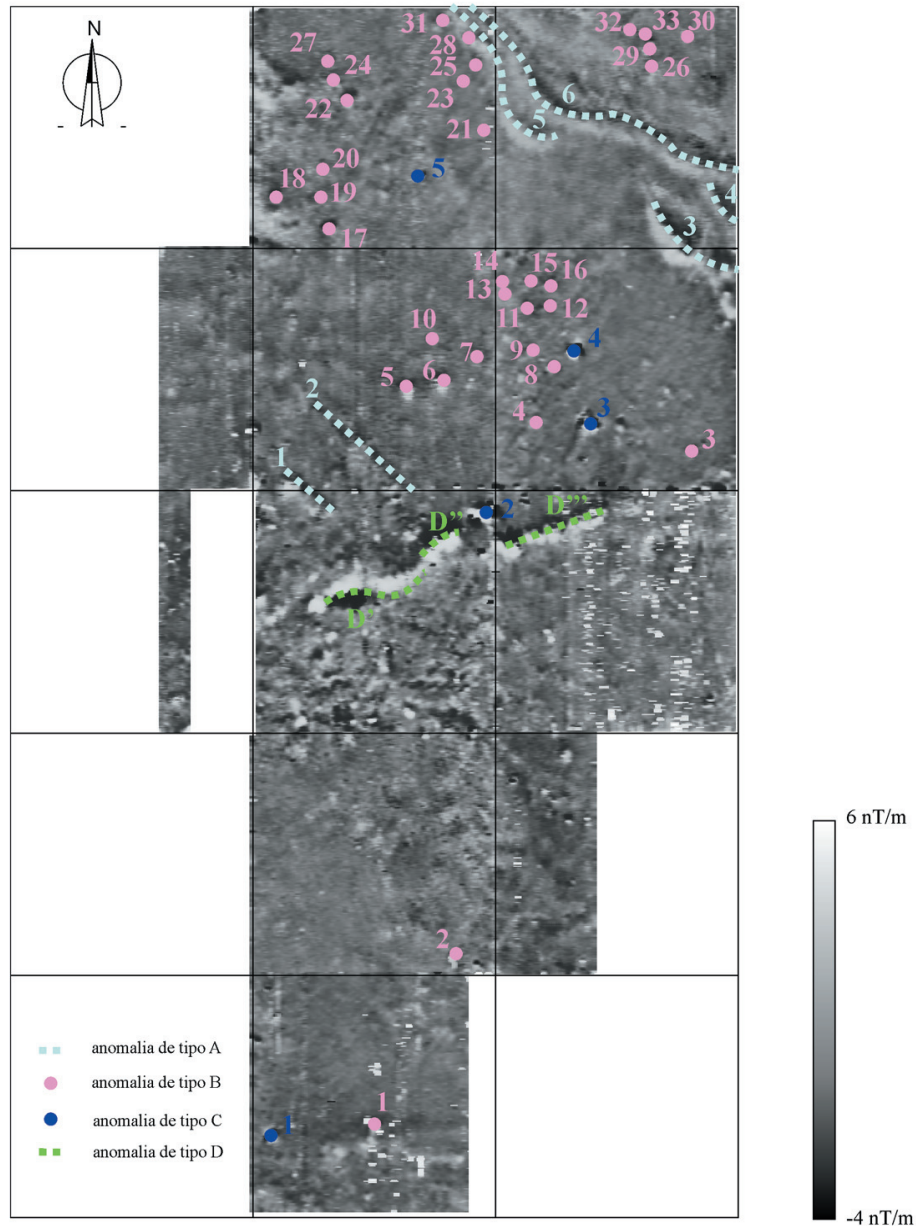

FIG. 9 - Anomalias detectadas na prospecção geomagnética de Terlamonte I. 

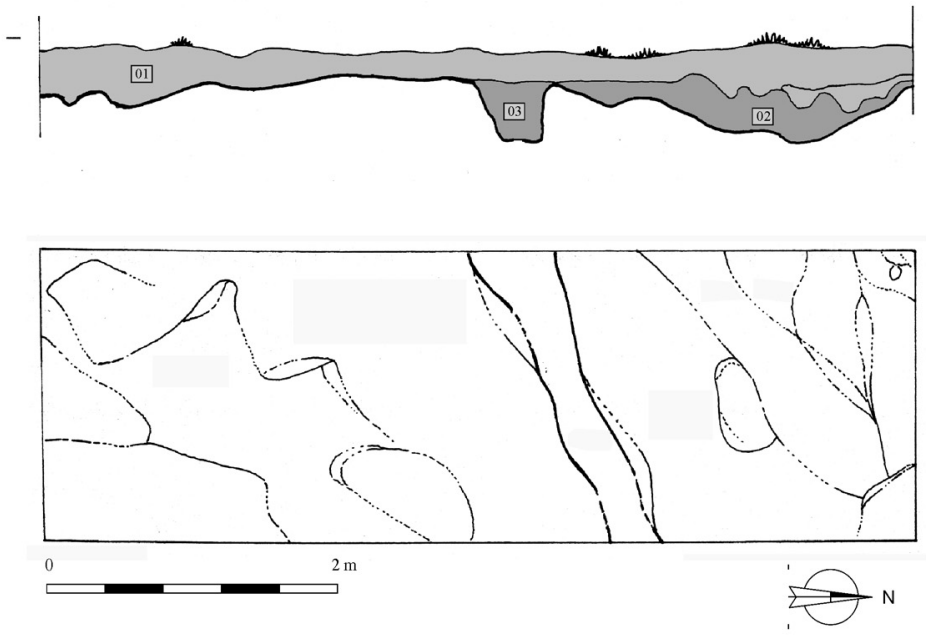

01

Terra castanho-escura, algo acinzentada, solta e granulosa; assenta sobre 01,03 e substrato rochoso; escassos fragmentos de tegulae e de cerâmica comum; unidade arável de superfície.

02

Terra amarelada, medianamente compacta e granulosa; assenta sobre o substrato rochoso; sem materiais arqueológicos associados; depósito de origem natural.

03

Terra castanho-alaranjada, compacta e argilosa; assenta sobre o substrato rochoso; sem materiais arqueológicos associados; depósito / veio de origem natural encaixado numa fractura do substrato rochoso.

FIG. 12 - Representação gráfica e descrição das U.E.'s da sondagem 4. 


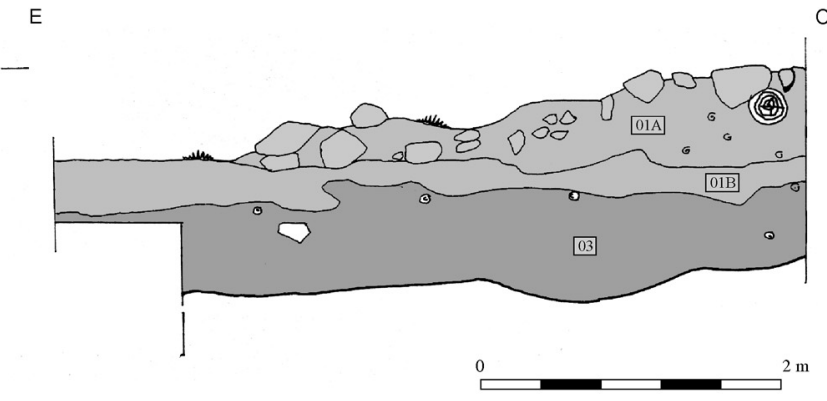

\section{1-A}

Terra castanha-muito escura, solta e granulosa; assenta sobre 01-B e envolve a 02; alguns fragmentos de tegulae, imbrices e de cerâmica comum; unidade arável de superfície.

\section{1-B}

Terra castanho-escura, solta e granulosa; assenta sobre 03; escassos fragmentos de tegulae, imbrices e cerâmica comum; unidade arável de superficie.

02.

Amontoado de pedras de pequena - média dimensão, não facetadas, envolvido por uma terra castanho-muito escura, solta e arenosa; envolvida pela 01-A; sem materiais arqueológicos associados; restos de muro de parcelamento.

\section{3}

Terra castanho-amarelada, medianamente compacta e granulosa; assenta sobre o saibro e a 05 e envolve a 04 ; sem materiais arqueológicos associados; depósito de origem natural.

\section{4}

Terra castanho-clara, muito solta e arenosa; assenta sobre o saibro; sem materiais arqueológicos associados; depósito de origem natural (?).

\section{5}

Terra avermelhada, muito compacta e algo argilosa; assenta sobre o saibro; sem materiais arqueológicos associados; depósito/veio de origem natural. 
N

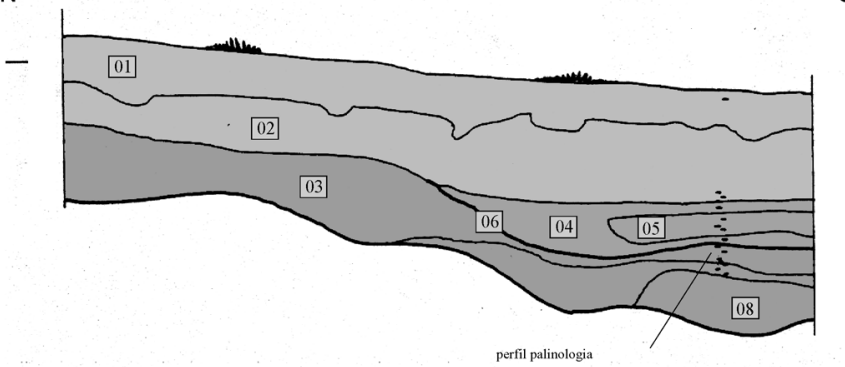

E

$\mathrm{O}$

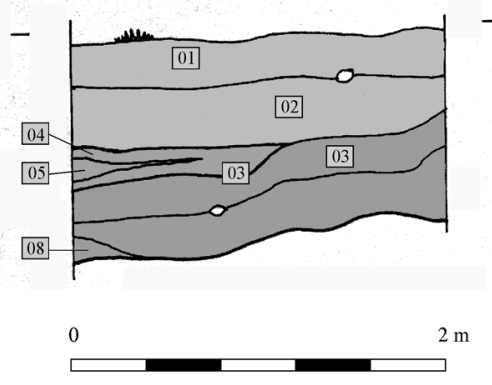

Terra castanho-escura, algo acinzentada, solta e arenosa; assenta sobre 02; alguns fragmentos de tegulae, imbrices, cerâmica comum (dolia) e escória; unidade arável de superfície.

02

Terra castanha-amarelada, solta e granulosa; assenta sobre 03 e 04 ; escassos fragmentos de tegulae e cerâmica comum; depósito de origem natural

03

Terra castanha-clara, algo alaranjada, compacta e granulosa; assenta sobre 07 e o substrato rochoso, sendo cortada por 06; sem materiais arqueológicos associados; o interface superior desta UE corresponderá à antiga linha topográfica aqui existente aquando da abertura/funcionamento de um paleo-canal (UE.s 04, 05 e 06).

04

Terra castanha-muito escura, quase negra, solta e arenosa extremamente fina; preenche o espaço definido por 06 e parece envolver a 05; sem materiais arqueológicos associados; enchimento de um possível paleo-canal.

05

Terra amarelada-beje, solta e arenosa, extremamente fina; preenche o espaço definido por 06 e parece ser envolvida pela 04; sem materiais arqueológicos associados; enchimento de um possível paleo-canal.

06

Elemento interfacial vertical que configura o paleo-canal assoreado / preenchido por $04 \mathrm{e} 05$; corta a 03

07

Terra castanha, porvezes castanha-escuro, medianamente compacta e granulosa; assenta sobre 08 e o substrato rochoso; sem materiais arqueológicos associados; depósito de origem natural.

08

Terra amarelada, compacta e granulosa / saibrosa; assenta sobre o substrato rochoso (circunscreve-se ao quadrante SE da sondagem); sem materiais arqueológicos associados; depósito de origem natural.

FIG. 14 - Representação gráfica e descrição das U.E.'s da sondagem 7. 


\begin{tabular}{|c|c|c|c|}
\hline$\because=$ & possível muro (anomalias geofisicas Ale A2) & $=$ & linha de drenagem \\
\hline$\Rightarrow=\mathrm{m}$ & paleocanal & $=$ & linha de água \\
\hline - & estrutura de redução de minério & & muro de lim. de prop. em desuso \\
\hline ? & possível estr. arqueológica & & muros ident. durante a escavação até 2003 \\
\hline $\mathbf{0}$ & fossa com mat. pré-históricos & & muros hipotéticos não confirmados \\
\hline- & vala? & & sondagens arqueológicas (2000-2001) \\
\hline
\end{tabular}

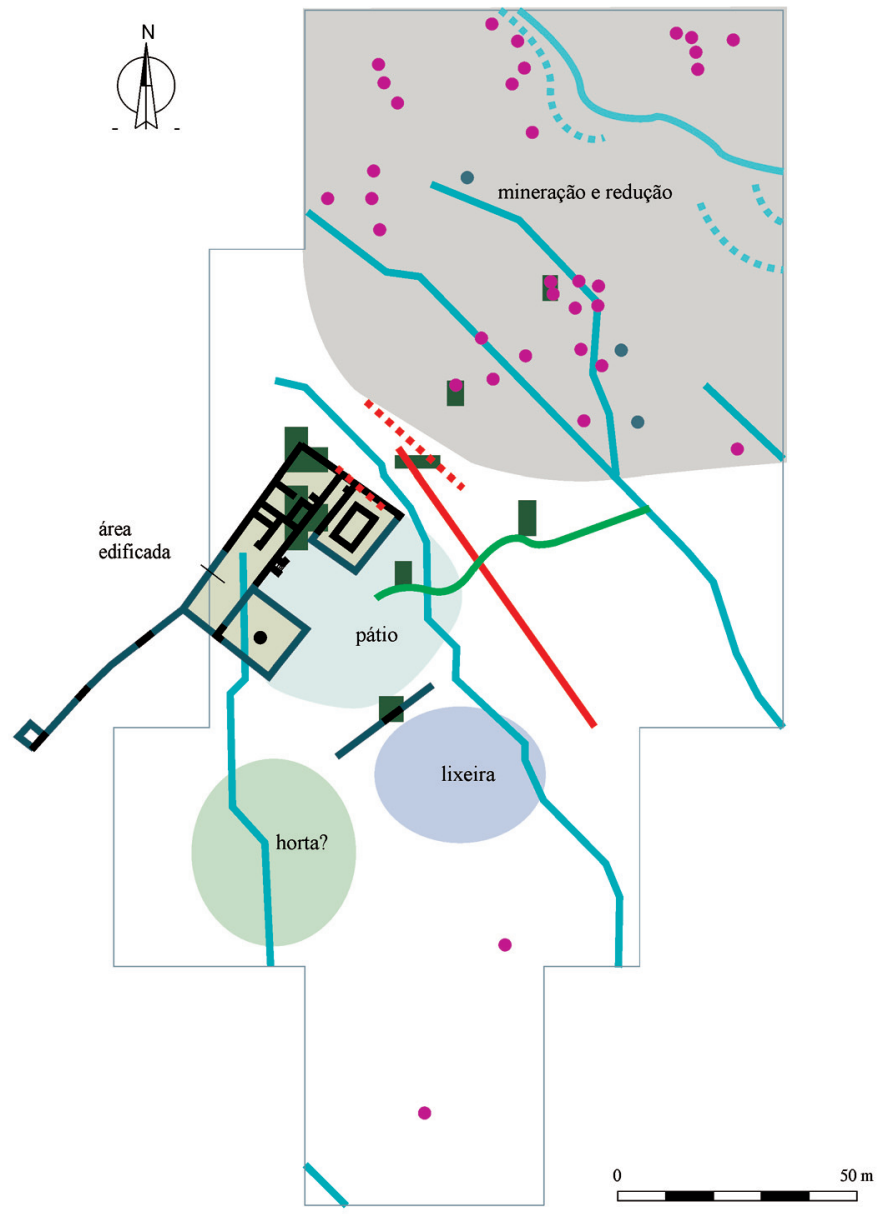

FIG. 15 - Planta interpretativa da intervenção arqueológica em Terlamonte I. 


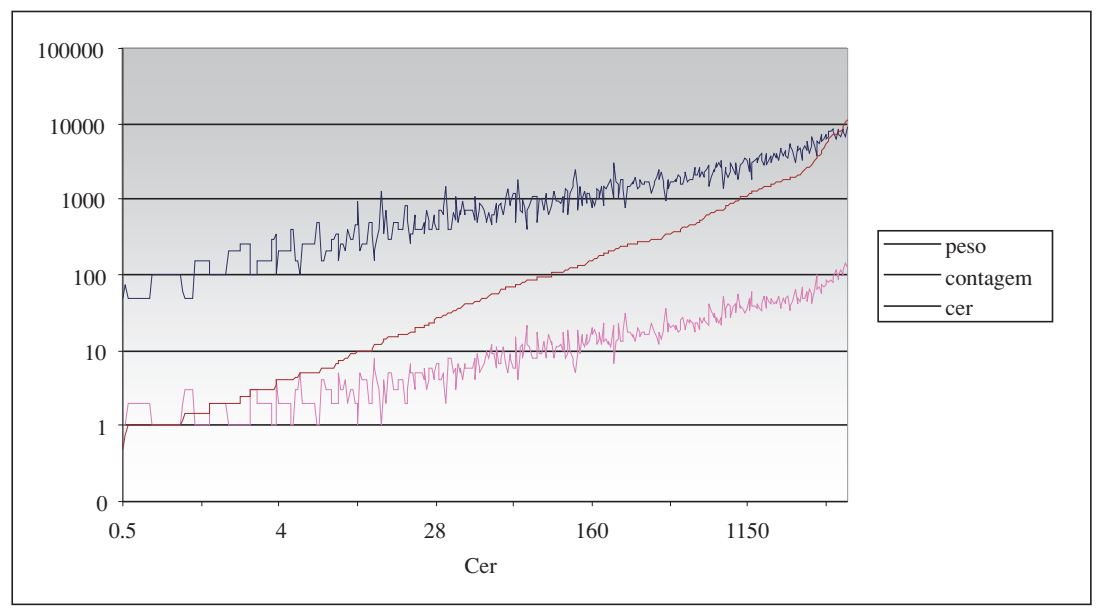

GRÁFICO 1 - Relação à escala logarítmica peso/quantidade/Cer no quadro da prospecção de superfície em quadrícula efectuada no sítio de Terlamonte I.

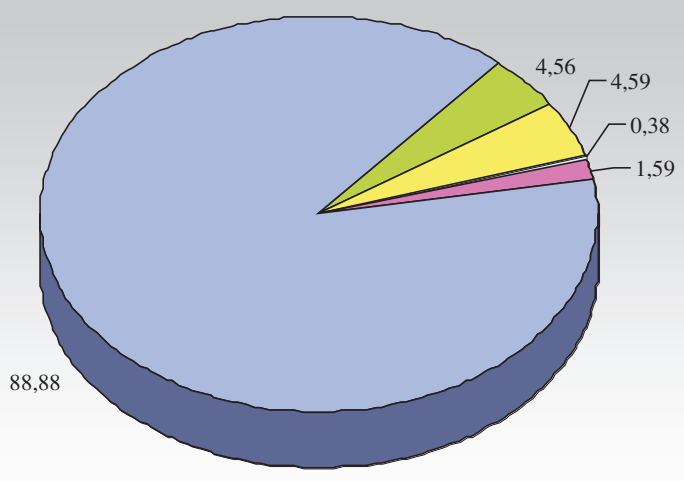

口 cerâm. de const.

$\square$ armazenamento

口mesa

口 sig. min. seix. tear

- minério

GRÁFICO 2 - Repartição percentual por tipos de materiais registados no quadro da prospecção intensiva em quadrícula efectuada no sítio de Terlamonte I. 


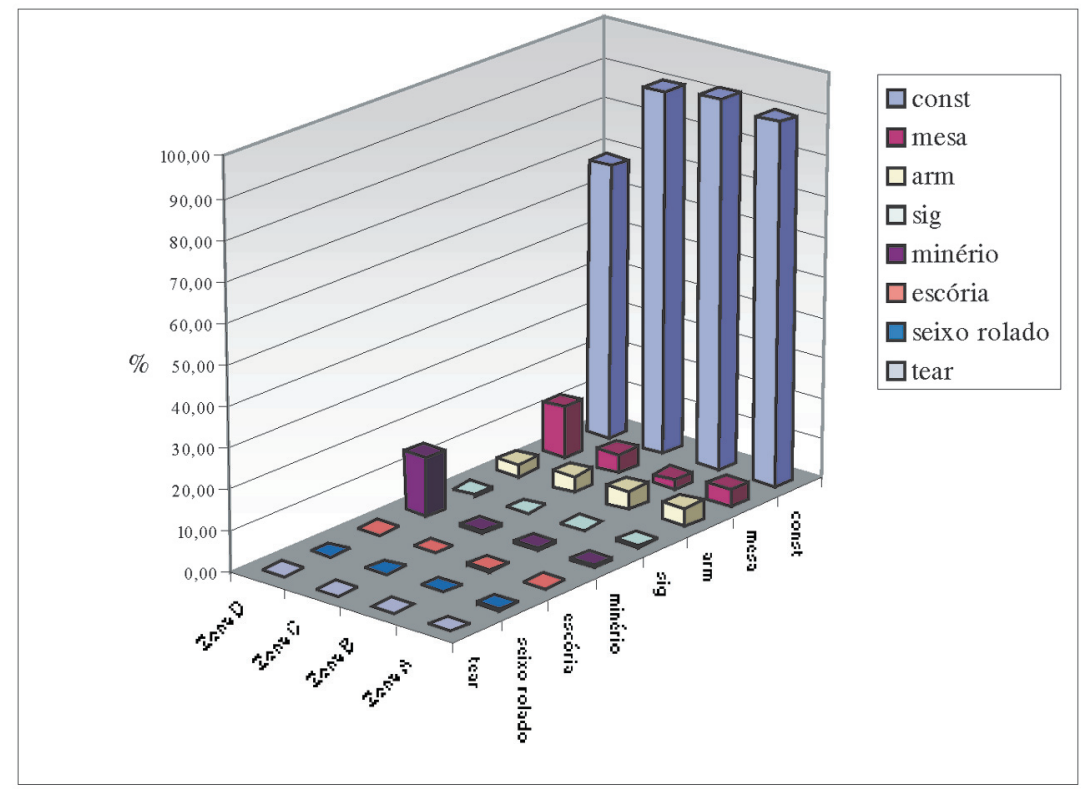

GRÁFICO 3 - Repartição percentual por zonas de densidades de materiais observadas no quadro da prospecção de superfície em quadrícula efectuada no sítio de Terlamonte I. 


\begin{tabular}{|c|c|c|c|c|c|c|c|c|c|c|}
\hline designação & $\mathbf{x}$ & $\mathbf{k}$ & yp & yn & zp & zn & alt, teórica & larg, teórica & erro q, & sondagens \\
\hline $\mathrm{A} 1$ & 65 & - & - & - & - & - & - & - & - & - \\
\hline $\mathrm{A} 2$ & 76 & - & - & - & - & - & - & - & - & 4 \\
\hline $\mathrm{A} 3$ & 134,5 & - & - & - & - & - & - & - & - & - \\
\hline A4 & 147 & - & - & - & - & - & - & - & - & - \\
\hline A5 & 109 & - & - & - & - & - & - & - & - & - \\
\hline A6 & 120 & - & - & - & - & - & - & - & - & - \\
\hline B1 & 75,5 & 7,97 & 17,96 & 18,49 & 0,47 & 0,59 & 0,12 & 0,53 & 0,72 & - \\
\hline B2 & 92 & 5,09 & 53,48 & 54,10 & 0,29 & 0,67 & 0,38 & 0,62 & 1,05 & - \\
\hline B3 & 141 & 4,96 & 158,13 & 158,50 & 0,36 & 0,58 & 0,22 & 0,37 & 0,92 & - \\
\hline B4 & 108 & - & - & - & - & - & - & - & - & - \\
\hline B5 & 81 & 19,98 & 171,10 & 171,73 & 0,96 & 1,25 & 0,28 & 0,64 & 1,32 & 2 \\
\hline B6 & 88,5 & 20,01 & 171,03 & 171,94 & 0,84 & 0,95 & 0,11 & 0,91 & 1,14 & - \\
\hline B7 & 95 & - & - & - & - & - & - & - & - & - \\
\hline B8 & 111,5 & 5,98 & 175,24 & 175,71 & 0,45 & 0,70 & 0,25 & 0,47 & 0,43 & - \\
\hline B9 & 107 & 14,99 & 178,22 & 178,75 & 0,80 & 1,44 & 0,64 & 0,53 & 0,72 & - \\
\hline B10 & 87 & 3,81 & 182,10 & 182,29 & 0,30 & 0,58 & 0,28 & 0,19 & 0,55 & - \\
\hline B11 & 106,5 & 4,37 & 187,47 & 188,87 & 0,51 & 0,90 & 0,39 & 1,40 & 0,65 & - \\
\hline B12 & 111 & 5,93 & 188,10 & 188,32 & 0,44 & 0,87 & 0,43 & 0,22 & 2,14 & - \\
\hline B13 & 102 & - & - & - & - & - & - & - & - & 1 \\
\hline B14 & 101 & 25,62 & 193,32 & 193,60 & 0,68 & 0,77 & 0,10 & 0,28 & 0,57 & 1 \\
\hline B15 & 108 & - & - & - & - & - & - & - & - & - \\
\hline B16 & 111 & - & - & - & - & - & - & - & - & - \\
\hline B17 & 66 & 9,99 & 204,22 & 205,00 & 0,58 & 0,70 & 0,12 & 0,78 & 0,95 & - \\
\hline B18 & 54,5 & 20,76 & 210,38 & 211,10 & 0,61 & 0,92 & 0,31 & 0,72 & 4,35 & - \\
\hline B19 & 64 & 0,75 & 211,08 & 212,63 & 0,17 & 0,41 & 0,24 & 1,55 & 0,17 & - \\
\hline B20 & 64 & 1,32 & 216,15 & 218,07 & 0,27 & 0,35 & 0,08 & 1,92 & 0,48 & - \\
\hline B21 & 97,5 & 2,62 & 223,91 & 224,33 & 0,19 & 0,17 & 0,01 & 0,42 & 0,66 & - \\
\hline B22 & 69 & 7,48 & 230,33 & 231,99 & 0,60 & 1,03 & 0,43 & 1,66 & 0,97 & - \\
\hline B23 & 96 & 7,41 & 238,26 & 239,92 & 0,64 & 1,69 & 1,05 & 1,66 & 0,25 & - \\
\hline B24 & 66 & 11,08 & 234,63 & 235,10 & 0,52 & 0,69 & 0,17 & 0,47 & 1,04 & - \\
\hline B25 & 98 & 2,66 & 241,50 & 243,44 & 0,55 & 0,57 & 0,03 & 1,94 & 0,26 & - \\
\hline B26 & 132,5 & - & - & - & - & - & - & - & - & - \\
\hline B27 & 65,5 & 3,10 & 238,52 & 239,99 & 0,29 & 0,86 & 0,57 & 1,47 & 0,43 & - \\
\hline B28 & 94,5 & 4,39 & 243,78 & 244,02 & 0,36 & 0,66 & 0,30 & 0,25 & 0,47 & - \\
\hline B29 & 131 & 3,97 & 241,10 & 241,92 & 0,29 & 0,67 & 0,38 & 0,82 & 1,07 & - \\
\hline B30 & 140 & 4,55 & 244,27 & 245,03 & 0,47 & 0,87 & 0,40 & 0,76 & 0,23 & - \\
\hline B31 & 89 & 5,05 & 246,98 & 247,58 & 0,40 & 0,76 & 0,36 & 0,59 & 0,48 & - \\
\hline B32 & 127,5 & 4,05 & 244,85 & 245,66 & 0,44 & 0,93 & 0,49 & 0,81 & 0,23 & - \\
\hline B33 & 131 & - & - & - & - & - & - & - & - & - \\
\hline $\mathrm{C} 1$ & 54 & - & - & - & - & - & - & - & - & - \\
\hline $\mathrm{C} 2$ & 98 & 58,04 & 144,56 & 145,57 & 0,51 & 0,89 & 0,37 & 1,01 & 8,39 & 5 \\
\hline $\mathrm{C} 3$ & 119,5 & 49,98 & 163,18 & 163,83 & 0,70 & 0,80 & 0,10 & 0,65 & 5,16 & - \\
\hline $\mathrm{C} 4$ & 116 & - & - & - & - & - & - & - & - & - \\
\hline C5 & 84,5 & 49,96 & 214,99 & 215,01 & 0,05 & 0,05 & 0,01 & 0,02 & 3,88 & - \\
\hline $\mathrm{D}^{\prime}$ & 72 & 30,02 & 130,52 & 127,85 & 1,26 & 0,77 & 0,49 & 2,67 & 5,52 & 7 \\
\hline $\mathrm{D}^{\prime \prime}$ & 90 & 43,20 & 139,22 & 141,75 & 0,76 & 1,43 & 0,67 & 2,53 & 4,14 & - \\
\hline $\mathrm{D}^{\prime \prime \prime}$ & 101,5 & 20,23 & 193,13 & 193,48 & 0,69 & 0,96 & 0,27 & 0,35 & 3,49 & - \\
\hline
\end{tabular}

TABELA 1 - Estimação da profundidade das anomalias registadas no quadro da prospecção geomagnética de Terlamonte I. 


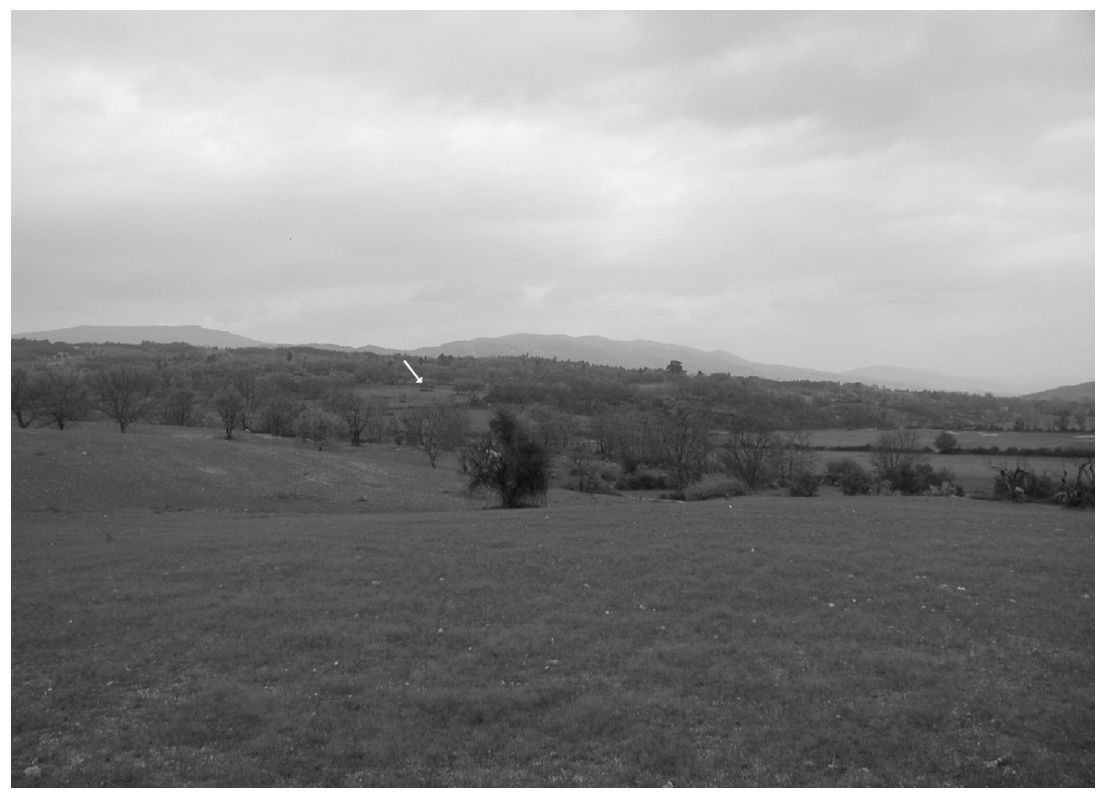

Foто 1 - Vista panorâmica de Terlamonte 1, aprox. S/N.

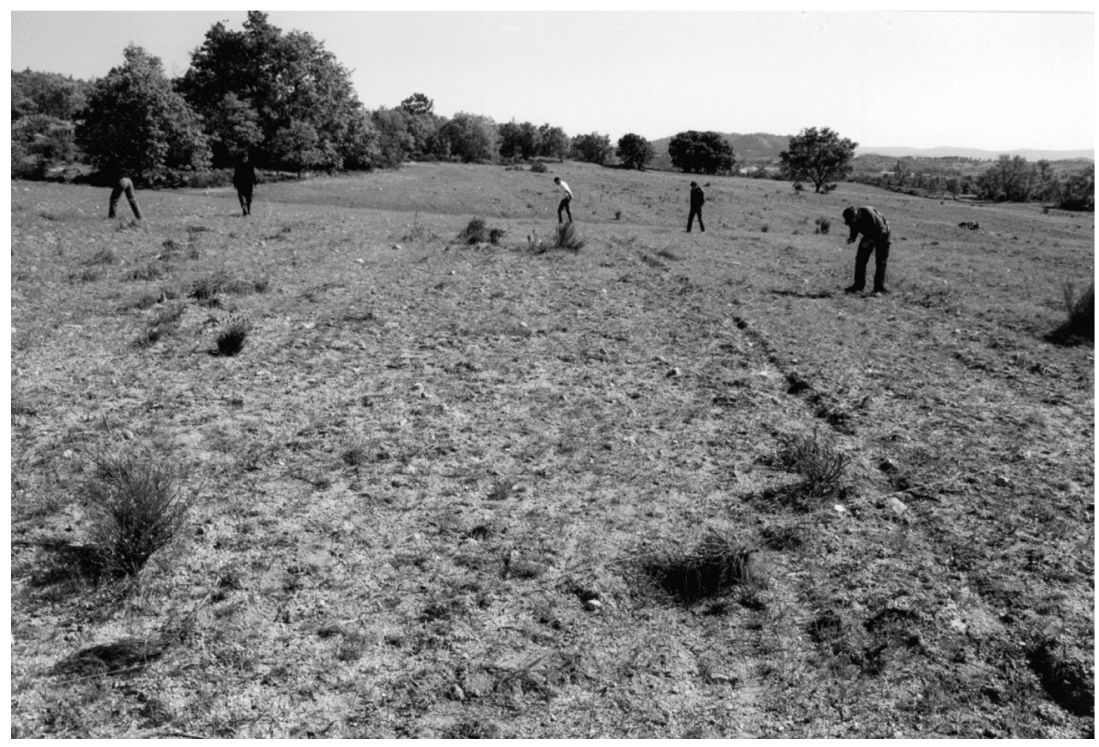

Fото 2 - Aspecto da prospecção de superfície em quadrícula no sector A. Vista aprox. S/N. 


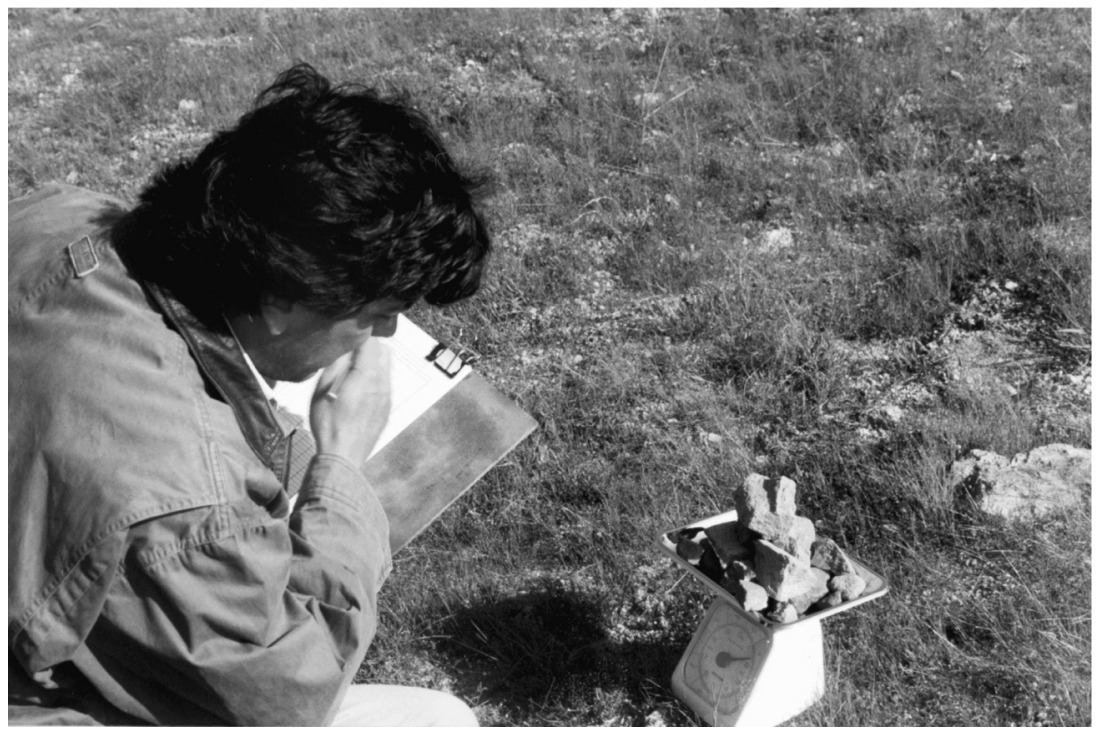

FOTо 3 - Aspecto da pesagem dos materiais cerâmicos no quadro da prospecção de superfície em quadrícula.

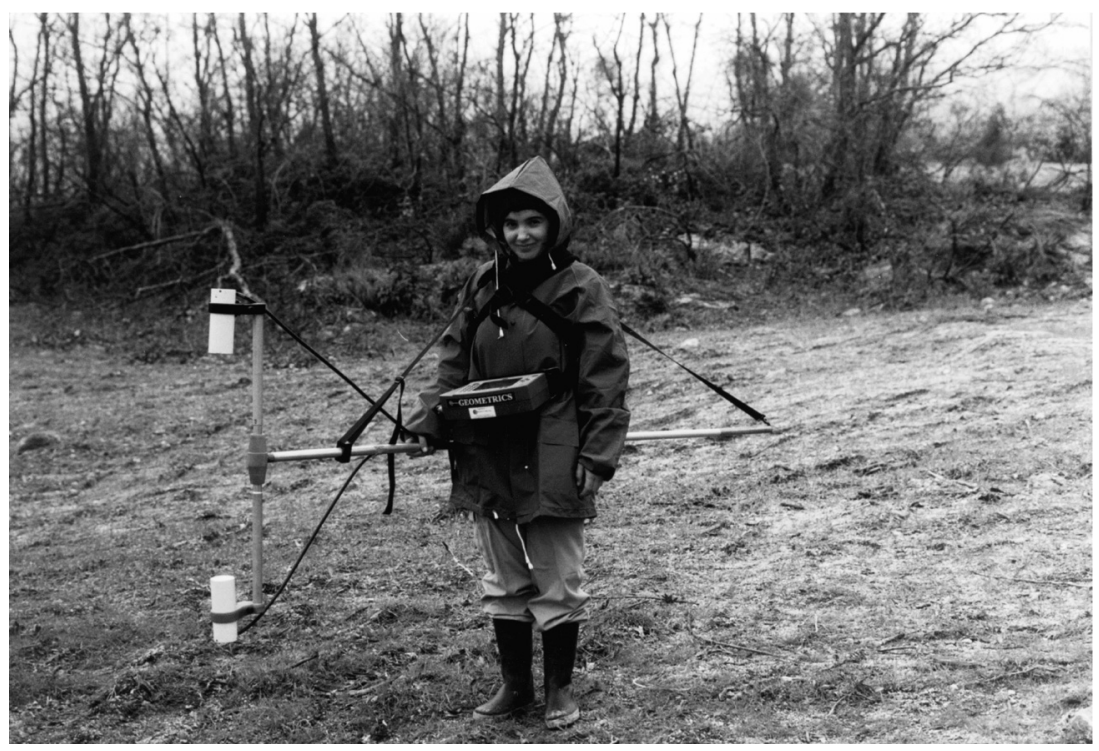

FOTо 4 - Operadora equipada com o magnetómetro a vapor de Césio G-858 da Geometrics. 


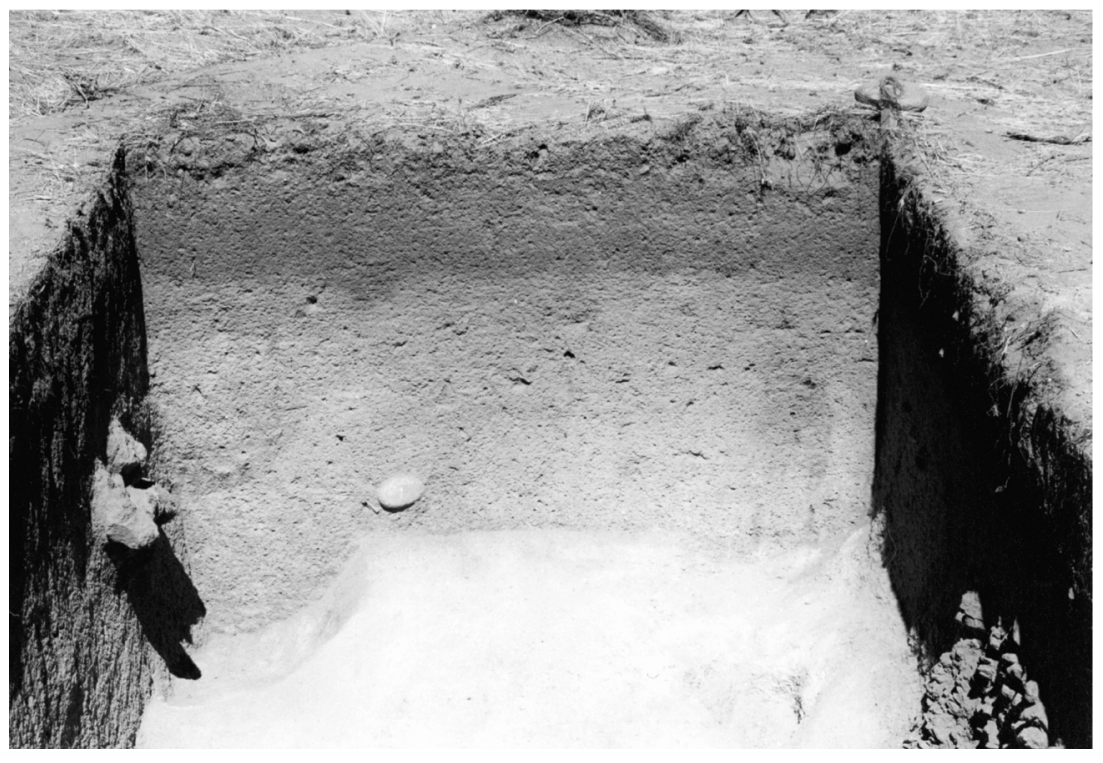

Fото 5 - Aspecto da estrutura 1 no final dos trabalhos de escavação da sondagem 1. Vista aprox. $\mathrm{S} / \mathrm{N}$.

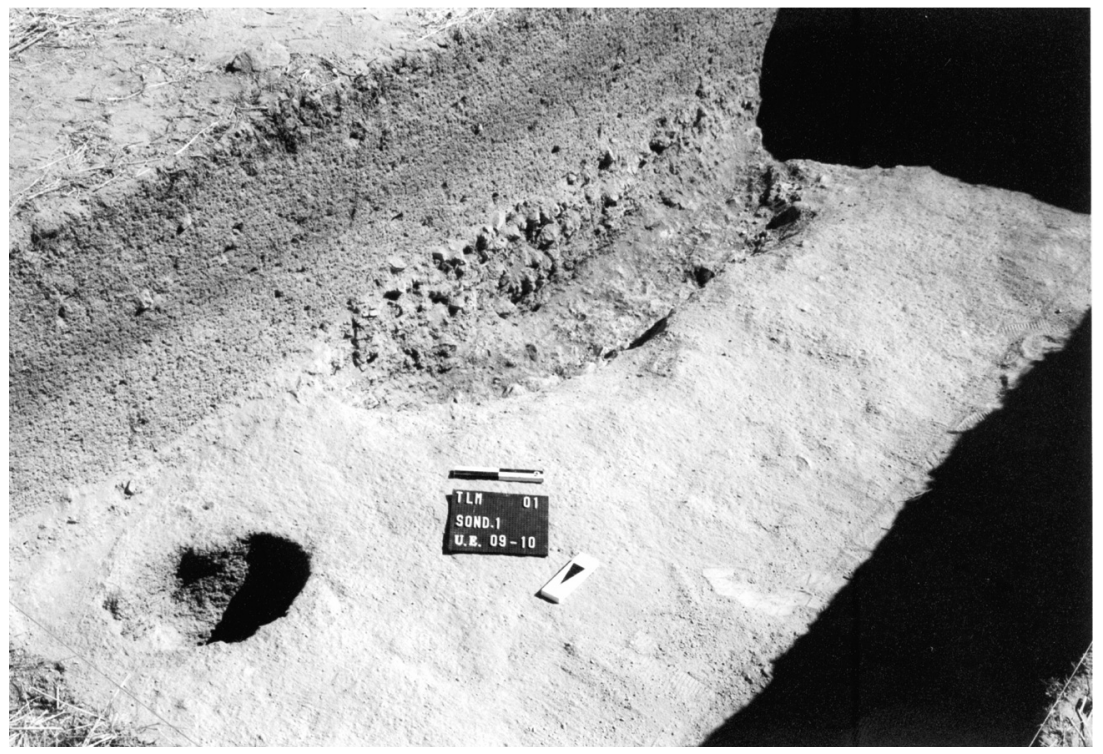

Foто 6 - Aspecto da [UE 4] (à direita) no final dos trabalhos de escavação da sondagem 1 . Vista aprox. NO/SE. 


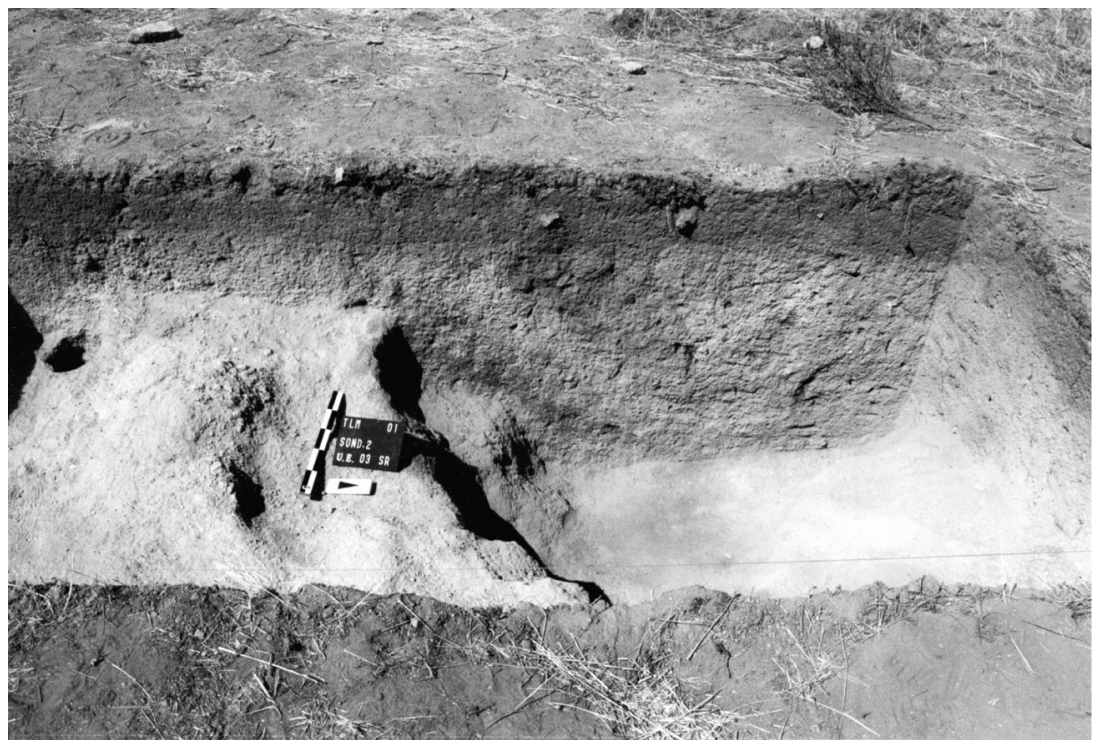

Fото 7 - Aspecto da estrutura 3 no final dos trabalhos de escavação da sondagem 2. Vista aprox. E/O.

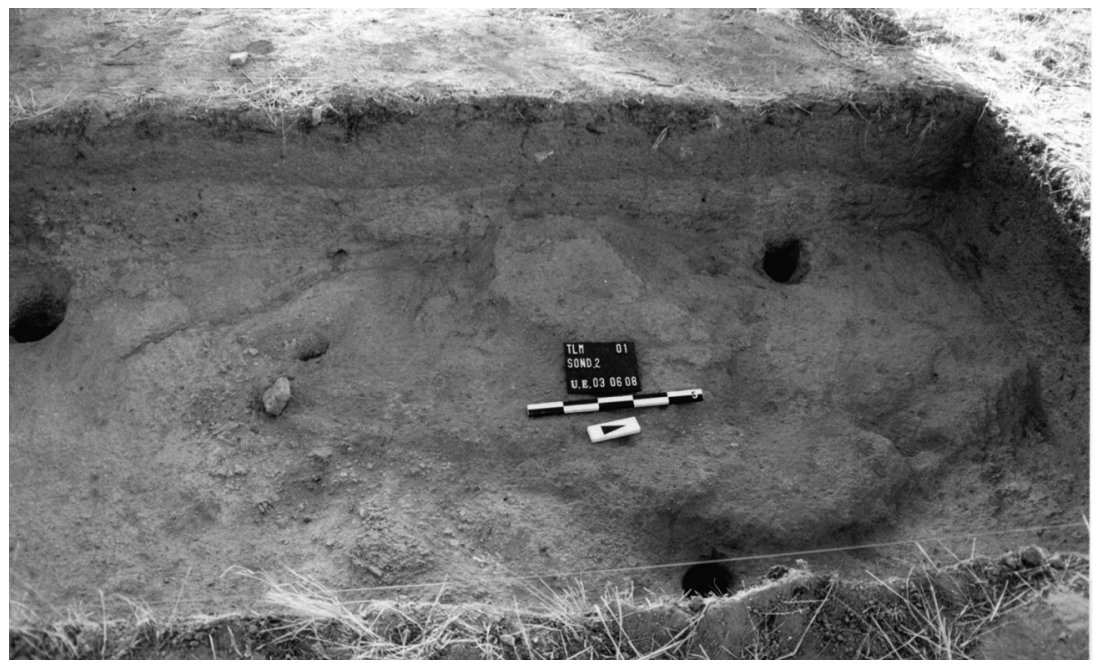

Fото 8 - Aspecto da estrutura 3 no decurso dos trabalhos de escavação da sondagem 2. Vista aprox. E/O. 


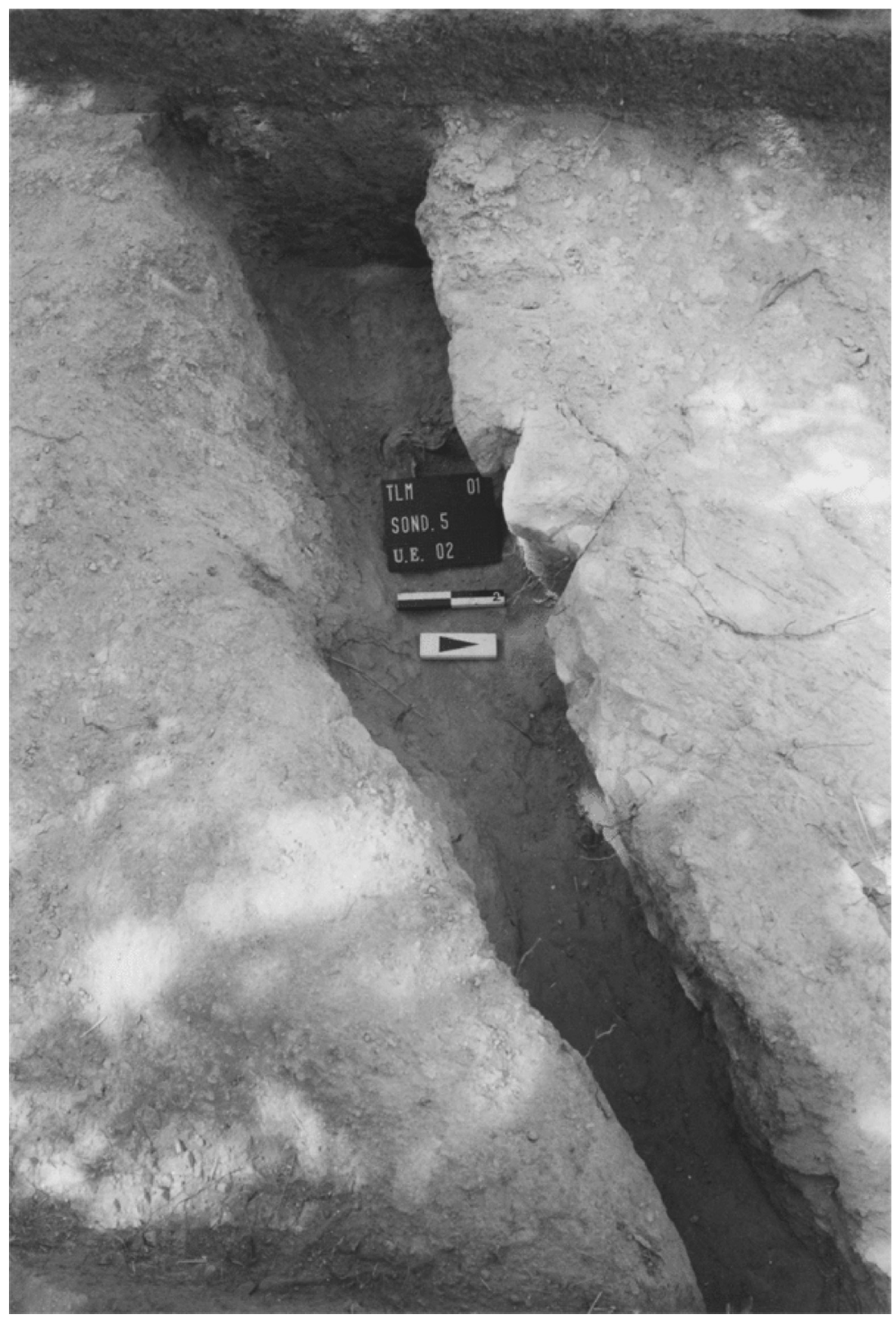

Fото 9 - Aspecto do veio de argila da sondagem 4, no final dos trabalhos de escavação. Vista aprox. E/O. 


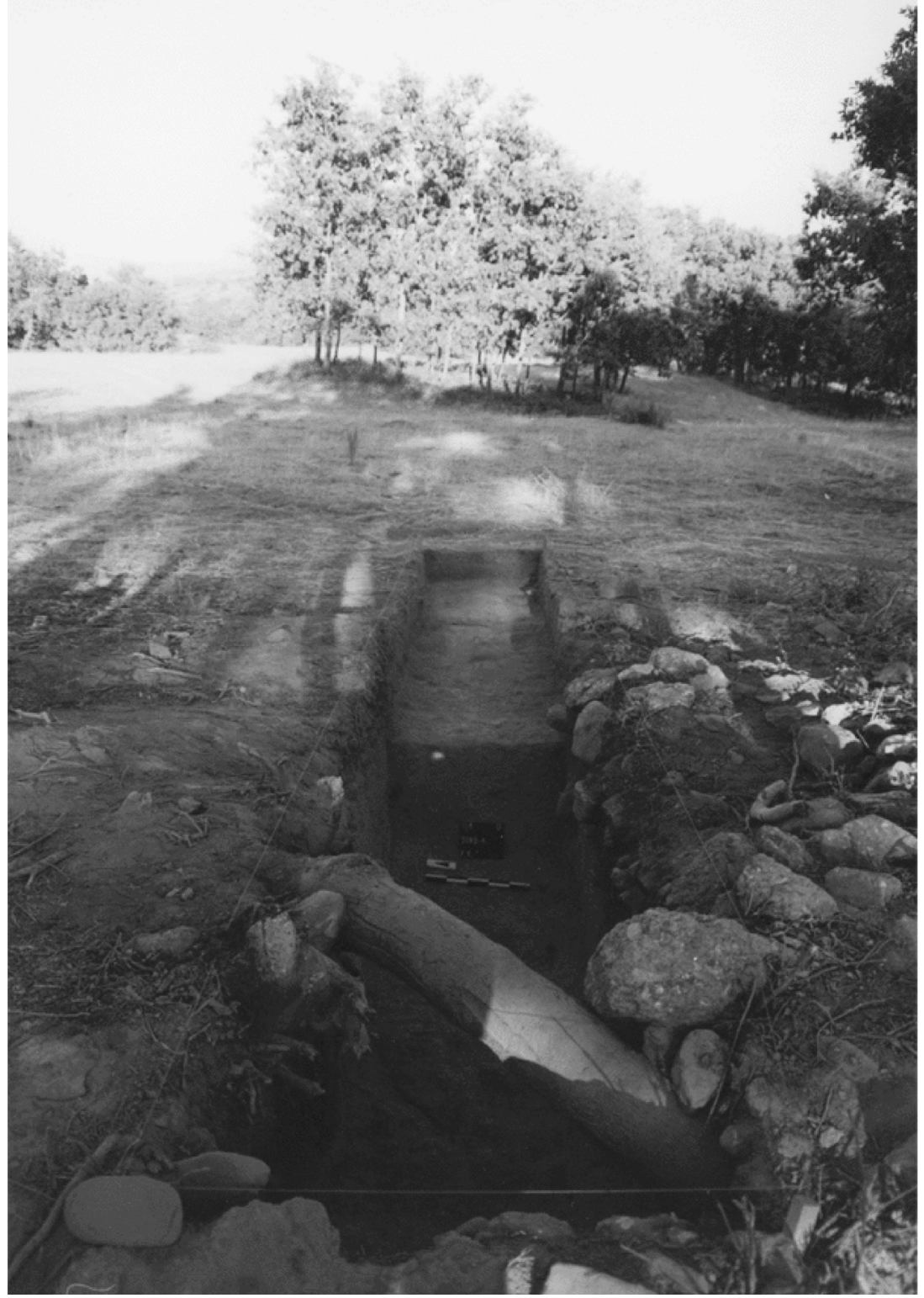

Fото 10 - Aspecto da sondagem 5, no final dos trabalhos de escavação.

Vista aprox. O/E. 


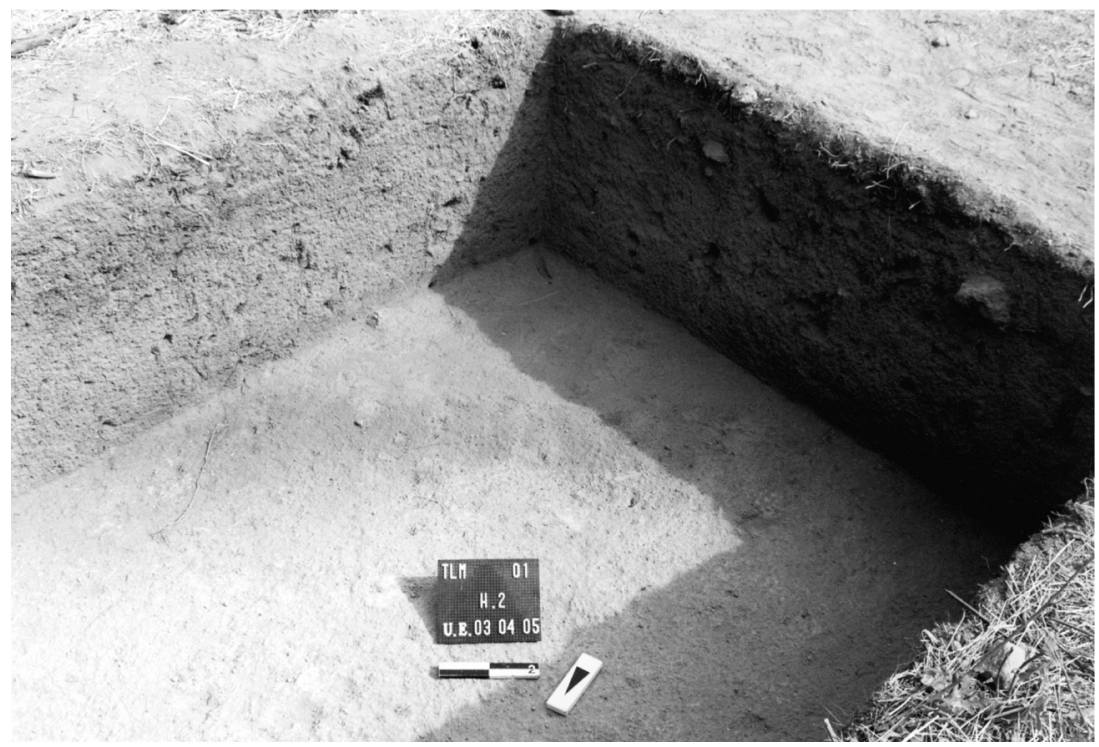

Foto 11 - Aspecto do depósito de siltes (U.E.'s 3, 4 e 5), no decurso da escavação da Sondagem 7. Vista aprox. NO/SE. 

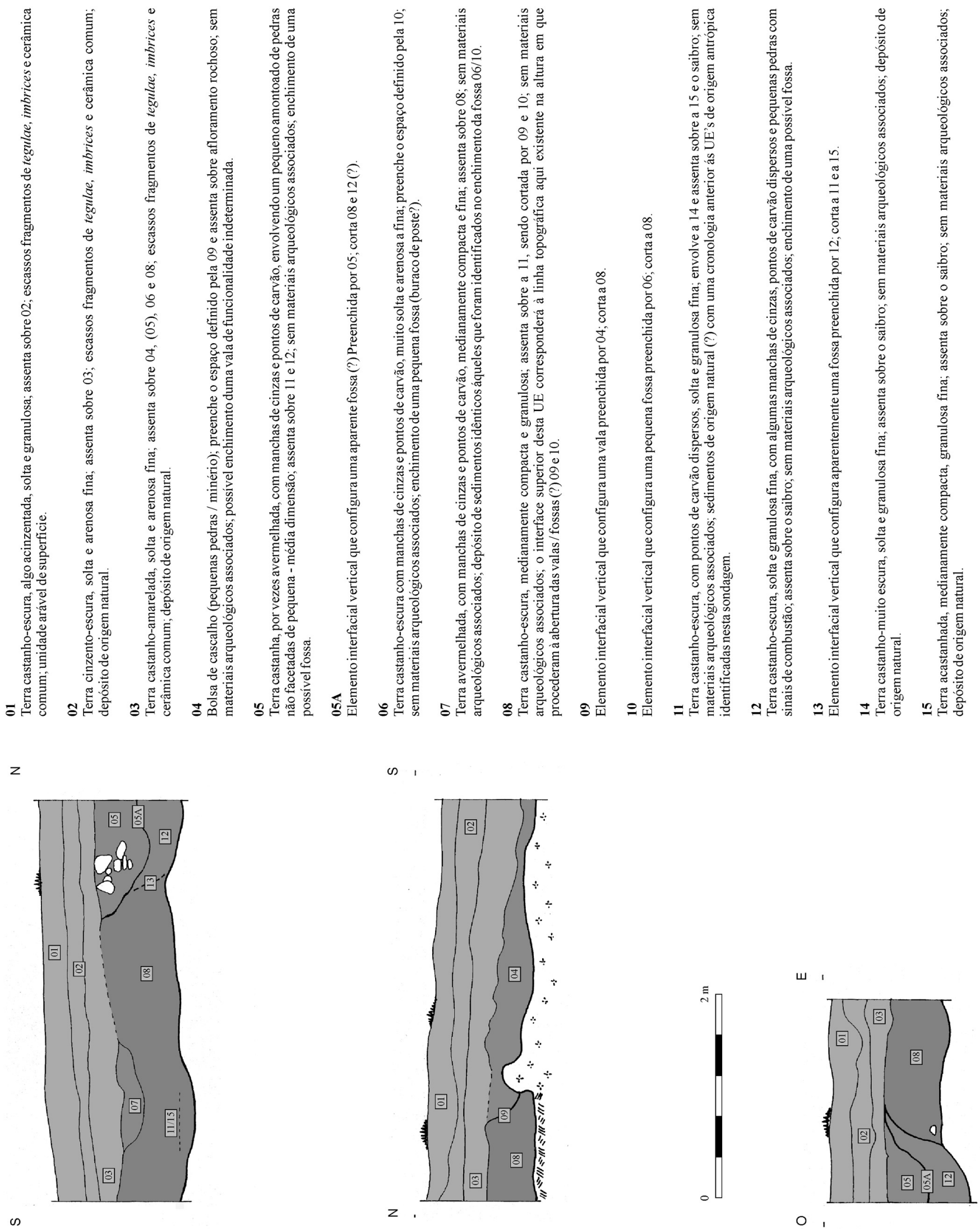

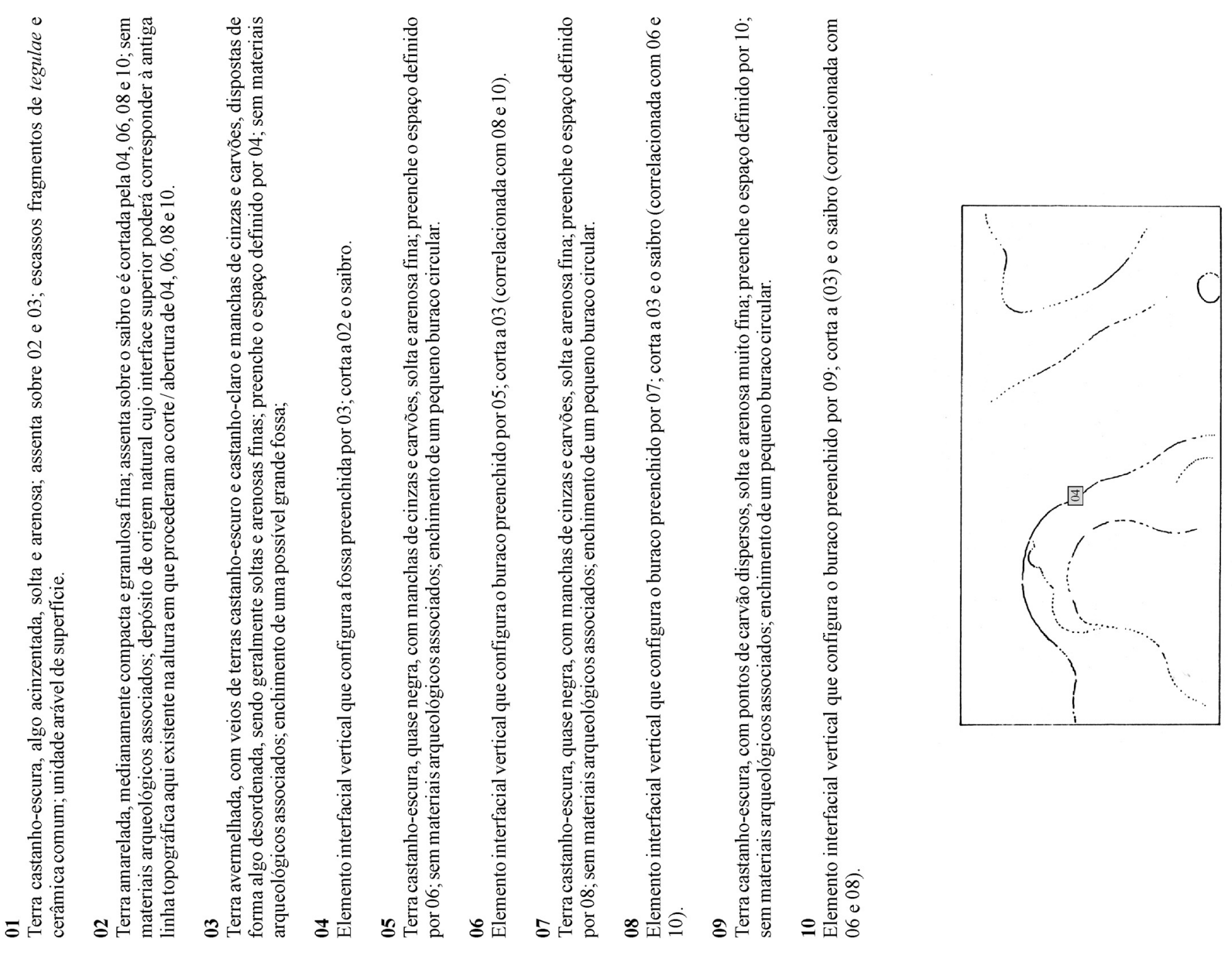

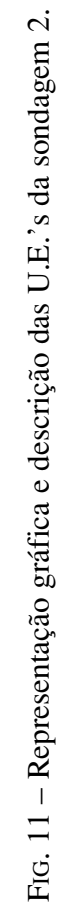
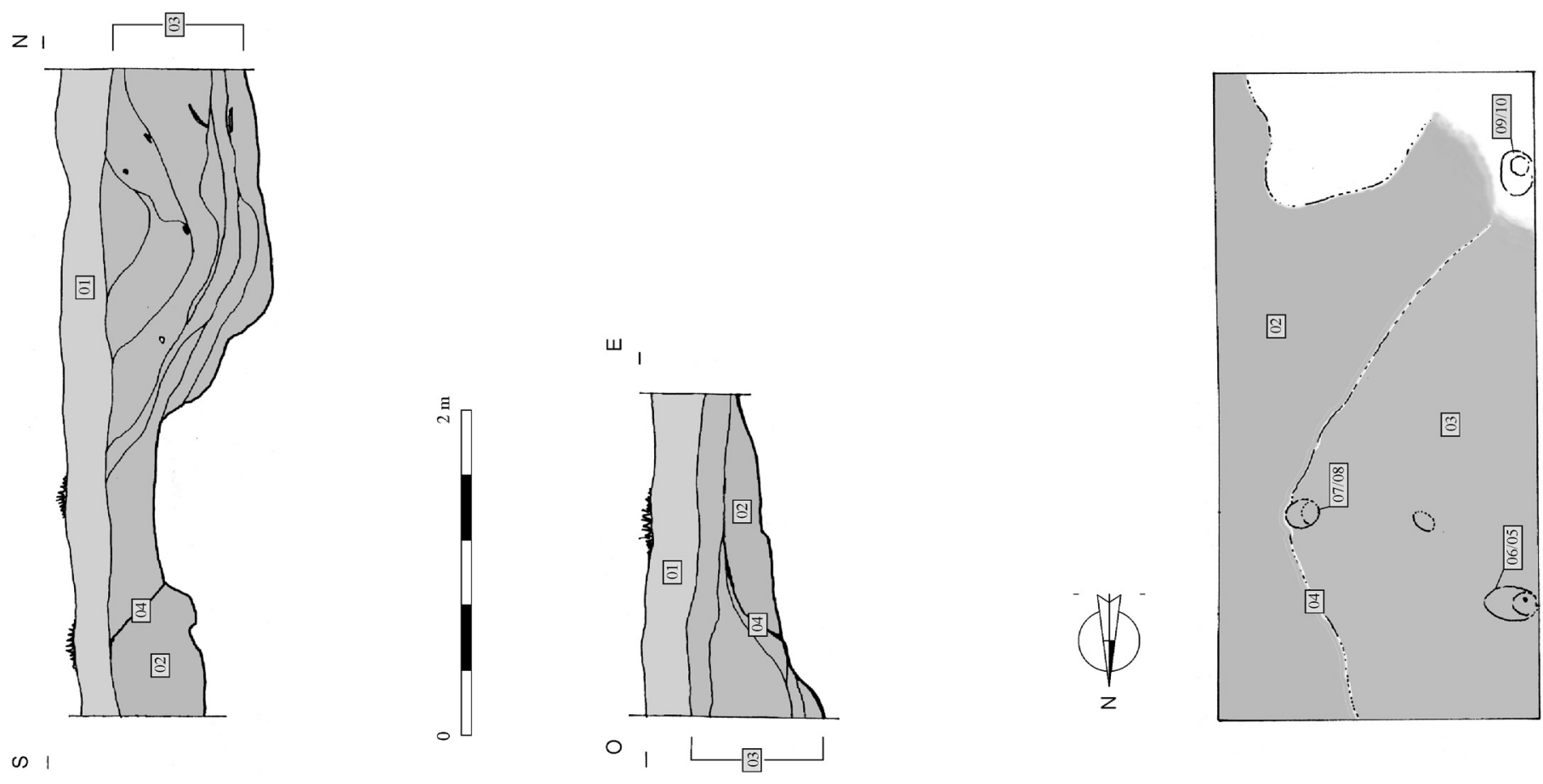

() 1
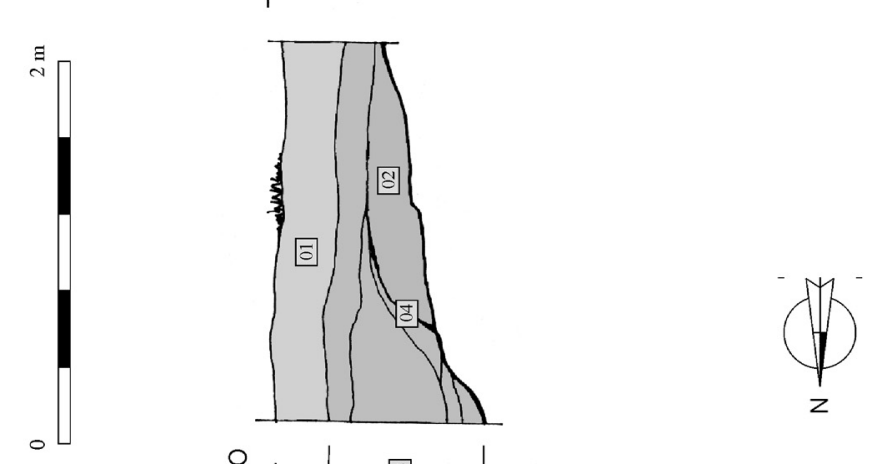